\title{
Biomimetic Self-assembly of Tetrapeptides into Fibrillar Networks and Organogels
}

\author{
Sajid Iqbal, ${ }^{[\mathrm{a}]}$ Juan F. Miravet $^{[\mathrm{a}] *}$ and Beatriu Escuder ${ }^{[\mathrm{a}] *}$
}

Keywords: self-assembly / gels / silk / $\beta$-sheet / fibers

\begin{abstract}
The self-assembly features of a family of tetrapeptides inspired in silk structure are presented. An exhaustive study of the influence of the terminal alkyl chain length in this process is undertaken. Scanning electron microscopy (SEM), wide-angle X-ray diffraction (WAXD), FTIR spectroscopy and circular dichroism are used for the structural analysis. These compounds, as in the natural model, self-assemble into antiparallel $\beta$-sheet structures that further organize to form fibrillar aggregates.
\end{abstract}

\begin{abstract}
Furthermore, some of them are capable of forming a crowded network that entraps the solvent leading to physical gels with different microscopic morphologies. A model for the assembly process is proposed.
\end{abstract}

(C) WILEY-VCH Verlag GmbH \& Co. KGaA, 69451 Weinheim, Germany, 2007) [a] Departament de Química Inorgànica i Orgànica, Universitat Jaume I, 12071 Castelló, Spain

Fax: +34 964729155

E-mail: escuder@qio.uji.es

Supporting information for this article is available on the WWW under http://www.eurjoc.org/ or from the author.

\section{Introduction}

Nature's high complexity and efficiency has always attracted attention of scientists, firstly to unravel its fascinating structures and processes and subsequently intending to imitate the beauty and harmony of them. For instance, mimicking the natural control of biomolecules conformation at the different levels of complexity and function has been an appealing goal. In this sense the study of protein structure and function has created a wide interest. ${ }^{[1,2]}$ It is well known that the different organization levels play an important role in different structural and functional proteins. For example, structural proteins (i.e. collagen, elastin and silks) base their physical properties in different aspects of their secondary structure. On the other hand, precisely folded switch points determine the active sites in catalytic proteins, enzymes. ${ }^{[3]}$ Furthermore, some devastating diseases such as amyloidogenic pathologies are related to anomalous protein folding that induces precipitation of toxic plaques. Recently, intense research has been devoted to the understanding of the amyloid aggregation mechanisms as well as to the development of strategies to prevent this unwanted process. ${ }^{[4]}$

In this context, the study of model systems, including peptides and small peptidomimetics, that self-assemble into fibrillar aggregates may help to determine the molecular basis for such processes. ${ }^{[5-8]}$ In connection with these studies' the formation of self-assembled fibrillar networks and gels from low molecular weight molecules has been studied extensively in the recent past. Many efforts in this field are directed towards an understanding of the role that the different structural elements present in the gelators play in the noncovalent association that yields the final fibrillar structures. ${ }^{[9-11]}$

In the last years we have been involved in the study of lowmolecular weight gelators based on amino acids. These small peptidomimetic compounds self-assemble into sheet-like extended structures that form fibrous aggregates and gels in different solvents. ${ }^{[12]}$ Recently, we have reported the design of a novel tetrapeptidic organogelator (4) based on a minimal sequence found in silks, Gly-L-Ala-Gly-L-Ala, and incorporating $C_{12}$ alkyl chains at both ends of the tetrapeptide. ${ }^{[13]} \mathrm{We}$ studied its self-assembly in organic solvents and it was revealed that this sequence showed a high preference for the antiparallel assembly into $\beta$-sheets (see Scheme 1).

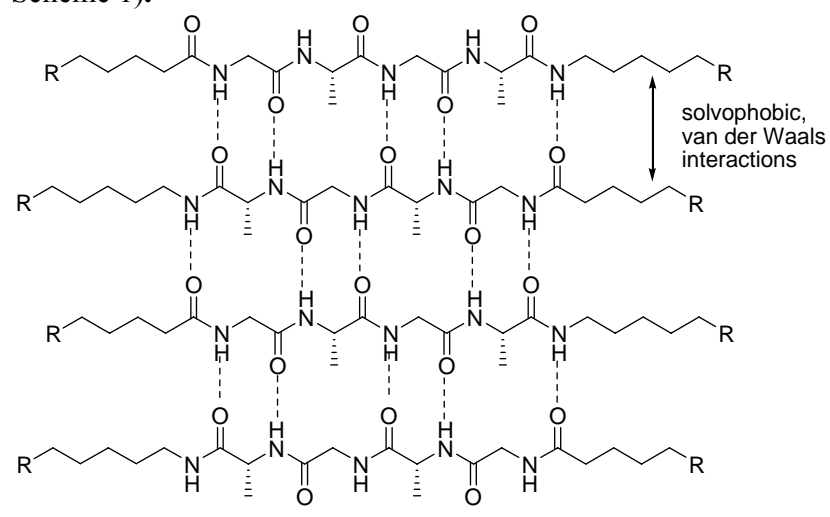

Scheme 1

In natural silk proteins, specific amino acids induce a turn in the polypeptidic chain causing its preorganization for an antiparallel $\beta$ sheet. In contrast, it is remarkable that in the reported gelator, that 'folding effect' was driven only by non-covalent interactions. We believe that this naturally selected one-dimensional assembly motif has a great potential for the design of new functional fibrous nanomaterials.

Here we report on the preparation and study of a library of compounds based on the variation of the terminal groups attached to the silk-mimetic tetrapeptide motif Gly-L-Ala-Gly-L-Ala (Scheme 2). Our aims include to clarify how the interplay of the non covalent interactions provided by apolar end moieties and the peptide core affect to the self-assembly of these molecules. The different nature of the intermolecular interactions provided by these moieties (van der Waals and solvophobic/solvophylic in one 
case and hydrogen bonding in the other case) is expected to allow for a fine tuning of the aggregation behaviour with the use, for example, of a variety of solvents. We are interested in assessing how properties such size and aspect of the microscopic fibers, gelation of different solvents, antiparallel peptide arrangement or microcrystalline packing are changed through a family of structurally related molecules.

\section{Results and Discussion}

A library of molecules containing different aliphatic $\left(\mathrm{C}_{12}, \mathrm{C}_{6}\right.$ or $\mathrm{C}_{3}$ alkyl radicals) and aromatic (phenyl and 4-nitrophenyl) end-chains were prepared. Most of the synthesized compounds bear different end groups on the peptide termini and a few of them are "symmetrically" substituted, bearing analogous side chains on both ends of the peptide (compounds 4, 5 and 6). The synthesis of these molecules was carried out using conventional peptide chemistry methods (Scheme 2). A convergent approach was used and the tetrapeptide derivatives 4-18 were obtained by coupling the corresponding dipeptide derivatives using EDC or DCC as coupling reagents. The preparation of $\mathrm{N}$-acylated dipeptides $\mathbf{3}$ was carried out by a Schotten-Baumann procedure. Compounds 2a-c were prepared by amide formation on the C-terminus of the Zprotected dipeptides and subsequent removal of the protecting group. All these compounds were fully characterized by NMR and MS (see Experimental Section).

Gelation studies. Firstly, the gelation capability of the compounds with alkyl end groups (4-13) in organic solvents was studied, and the results are collected in Table 1. In general, all compounds were poorly soluble and had to be heated at the boiling temperature of the solvent to obtain a clear solution. After cooling at room temperature many of them formed gels and some gave place to phase separation by formation of aggregates that could not be defined as proper gels but as weak gels or colloidal precipitates. In general, gels were obtained both in polar and apolar solvents, and most of them were transparent at their minimum gel concentration $(\mathrm{mgc})$.

It is interesting to compare the gelation properties of the compounds that present analogous alkyl chains on both ends of the peptide (compounds 4, 5 and 6 which present respectively $\mathrm{C}_{12}, \mathrm{C}_{6}$ and $\mathrm{C}_{3}$ chains). It can be observed that in the more polar solvents the compound with $\mathrm{C}_{6}$ chains (5) is in general a better gelator than $4\left(\mathrm{C}_{12}\right.$ chains) which is not forming proper gels in alcohols. It could be argued that in compound 4 the long $\mathrm{C}_{12}$ end chains preclude gel formation in polar solvents. Although solvophobic interactions are expected to be important for aliphatic chains in polar solvents, it seems that the long and flexible $\mathrm{C}_{12}$ chains may not be contributing significantly to the 1-D aggregation motif shown in Scheme 1<smiles>C[C@H](NC(=O)CN)C(=O)O</smiles><smiles>[R]C(=O)NCC(=O)N[C@@H](C)C(=O)O</smiles>

3a $\mathrm{R}=-\mathrm{CH}_{2}-\mathrm{CH}_{3}$ b $\mathrm{R}=-\mathrm{CH}_{2}-\left(\mathrm{CH}_{2}\right)_{3}-\mathrm{CH}_{3}$ c $\mathrm{R}=-\mathrm{CH}_{2}-\left(\mathrm{CH}_{2}\right)_{9}-\mathrm{CH}_{3}$ d $\mathrm{R}=\mathrm{Ph}-$ e $\mathrm{R}=4-\mathrm{NO}_{2} \mathrm{Ph}$ -<smiles>C[C@H](NC(=O)CNC(=O)OCc1ccccc1)C(=O)O</smiles$\mathrm{R}^{\prime} \mathrm{NH}_{2}$ DCC, DME<smiles>[R]NC(=O)[C@H](C)NC(=O)CNC(=O)OCc1ccccc1</smiles>
$\mathrm{H}_{2}, \mathrm{Pd} / \mathrm{C}$<smiles>[R]NC(=O)[C@H](C)NC(=O)CN</smiles><smiles>CC(=O)OC(=O)C(C)C(C)C</smiles><smiles>[R]NC(=O)[C@H](C)NC(=O)CNC(=O)[C@H](C)NC(=O)CNC([R])=O</smiles>

$4 \mathrm{R}=-\mathrm{CH}_{2}-\left(\mathrm{CH}_{2}\right)_{9}-\mathrm{CH}_{3}$ R'=- $\mathrm{CH}_{2}-\left(\mathrm{CH}_{2}\right)_{10}-\mathrm{CH}_{3}$

$5 \mathrm{R}=-\mathrm{CH}_{2}-\left(\mathrm{CH}_{2}\right)_{3}-\mathrm{CH}_{3} \quad \mathrm{R}^{\prime}=-\mathrm{CH}_{2}-\left(\mathrm{CH}_{2}\right)_{4}-\mathrm{CH}_{3}$

$6 \mathrm{R}=-\mathrm{CH}_{2}-\mathrm{CH}_{3} \quad \mathrm{R}^{\prime}=-\mathrm{CH}_{2}-\mathrm{CH}_{2}-\mathrm{CH}_{3}$

$7 \mathrm{R}=-\mathrm{CH}_{2}-\left(\mathrm{CH}_{2}\right)_{9}-\mathrm{CH}_{3} \mathrm{R}^{\prime}=-\mathrm{CH}_{2}-\left(\mathrm{CH}_{2}\right)_{4}-\mathrm{CH}_{3}$

$8 \mathrm{R}=-\mathrm{CH}_{2}-\left(\mathrm{CH}_{2}\right)_{9}-\mathrm{CH}_{3} \quad \mathrm{R}^{\prime}=-\mathrm{CH}_{2}-\mathrm{CH}_{2}-\mathrm{CH}_{3}$

$9 \mathrm{R}=-\mathrm{CH}_{2}-\left(\mathrm{CH}_{2}\right)_{3}-\mathrm{CH}_{3} \mathrm{R}^{\prime}=-\mathrm{CH}_{2}-\left(\mathrm{CH}_{2}\right)_{10}-\mathrm{CH}_{3}$

$10 \mathrm{R}=-\mathrm{CH}_{2}-\left(\mathrm{CH}_{2}\right)_{3}-\mathrm{CH}_{3} \mathrm{R}^{\prime}=-\mathrm{CH}_{2}-\mathrm{CH}_{2}-\mathrm{CH}_{3}$

$11 \mathrm{R}=-\mathrm{CH}_{2}-\mathrm{CH}_{3} \quad \mathrm{R}^{\prime}=-\mathrm{CH}_{2}-\left(\mathrm{CH}_{2}\right)_{10}-\mathrm{CH}_{3}$

$12 \mathrm{R}=-\mathrm{CH}_{2}-\mathrm{CH}_{3} \quad \mathrm{R}^{\prime}=-\mathrm{CH}_{2}-\left(\mathrm{CH}_{2}\right)_{4}-\mathrm{CH}_{3}$

$13 \mathrm{R}=\mathrm{Ph}-$

$14 \mathrm{R}=4-\mathrm{NO}_{2} \mathrm{Ph}-$

$15 \mathrm{R}=\mathrm{Ph}-$

$16 \mathrm{R}=4-\mathrm{NO}_{2} \mathrm{Ph}-$

$17 \mathrm{R}=\mathrm{Ph}-$

$18 \mathrm{R}=4-\mathrm{NO}_{2} \mathrm{Ph}$ -

$19 \mathrm{R}=\mathrm{PhCH}_{2} \mathrm{O}$ -

$\mathrm{R}^{\prime}=-\mathrm{CH}_{2}-\mathrm{CH}_{2}-\mathrm{CH}_{3}$

$\mathrm{R}^{\prime}=-\mathrm{CH}_{2}-\mathrm{CH}_{2}-\mathrm{CH}_{3}$ $\mathrm{R}^{\prime}=-\mathrm{CH}_{2}-\left(\mathrm{CH}_{2}\right)_{4}-\mathrm{CH}_{3}$ $\mathrm{R}^{\prime}=-\mathrm{CH}_{2}-\left(\mathrm{CH}_{2}\right)_{4}-\mathrm{CH}_{3}$ $\mathrm{R}^{\prime}=-\mathrm{CH}_{2}-\left(\mathrm{CH}_{2}\right)_{10}-\mathrm{CH}_{3}$ $\mathrm{R}^{\prime}=-\mathrm{CH}_{2}-\left(\mathrm{CH}_{2}\right)_{10}-\mathrm{CH}_{3}$ $\mathrm{R}^{\prime}=4-\mathrm{NO}_{2} \mathrm{Ph}-$

Scheme 2

On the other hand, if the gelation capability of compounds $5\left(\mathrm{C}_{6}\right.$ end chains) and 6 ( $\mathrm{C}_{3}$ end chains) is compared it can be noticed that significant differences can be observed in solvents which present low or moderate polarity. For example in toluene compound 5 forms gels at a mgc value of $9 \mathrm{mM}$ while compound 6 is forming a precipitate. This behaviour is related to that observed, for instance, in dichloromethane where the compound $\mathbf{5}$ forms gel while compound $\mathbf{6}$ is insoluble. These results can be easily rationalized having in mind that hydrogen bonding interactions can be dominant in solvents of low to moderate polarity and that in these solvents the alkyl chains may play a role in the solubilisation of the molecules by favorable interactions with the solvent. In the 
case of molecule 6 , the reported behaviors could be ascribed to the fact that the $\mathrm{C}_{3}$ chains are too short. They would preclude the formation the long aggregates required for fiber formation due to the insoluble nature of the associated species. On the contrary, $\mathrm{C}_{6}$ (and $\mathrm{C}_{12}$ ) chains would impart the required solubility, for example, in toluene. This line of reasoning would explain the fact that in the most apolar solvent, cyclohexane, gels are formed only with the compound with $\mathrm{C}_{12}$ chains, 4 .

Table 1. Gelation behavior of compounds 4-12 $(5 \mathrm{mg} / \mathrm{mL}){ }^{\mathrm{a}, \mathrm{b}}$

\begin{tabular}{|c|c|c|c|c|c|c|c|c|c|}
\hline \multirow[t]{2}{*}{ Solvent } & \multicolumn{9}{|c|}{ Compound } \\
\hline & 4 & 5 & 6 & 7 & 8 & 9 & 10 & 11 & 12 \\
\hline Methanol & A & WG & WG & $\mathrm{P}$ & $\begin{array}{c}\mathrm{G} \\
(10)\end{array}$ & $\begin{array}{l}\text { G } \\
\text { (9) }\end{array}$ & WG & A & $\begin{array}{c}\mathrm{G} \\
(12)\end{array}$ \\
\hline Ethanol & WG & $\begin{array}{c}\mathrm{G} \\
\text { (11) }\end{array}$ & $\begin{array}{c}G \\
(13)\end{array}$ & WG & $\begin{array}{c}\mathrm{G} \\
(10)\end{array}$ & $\begin{array}{l}\text { G } \\
\text { (9) }\end{array}$ & $\begin{array}{c}G \\
(12)\end{array}$ & $\begin{array}{c}G \\
(10)\end{array}$ & $\begin{array}{c}\mathrm{G} \\
(12)\end{array}$ \\
\hline 2-Propanol & A & $\begin{array}{c}G \\
\text { (7) }\end{array}$ & WG & $\mathrm{G}(9)$ & $\begin{array}{c}G \\
(3)\end{array}$ & $\begin{array}{l}\text { G } \\
\text { (7) }\end{array}$ & $\begin{array}{c}G \\
(5)\end{array}$ & $\mathrm{A}$ & $\begin{array}{c}G \\
(12)\end{array}$ \\
\hline Cyclohexanol & S & $\begin{array}{c}\mathrm{G} \\
(11)\end{array}$ & $\begin{array}{c}\text { G } \\
(13)\end{array}$ & $\mathrm{A} / \mathrm{P}$ & $\begin{array}{c}\mathrm{G} \\
(10)\end{array}$ & $\begin{array}{l}\text { G } \\
\text { (9) }\end{array}$ & $\begin{array}{c}\mathrm{G} \\
(12)\end{array}$ & $\begin{array}{c}G \\
(10)\end{array}$ & $\begin{array}{c}\mathrm{G} \\
\text { (12) }\end{array}$ \\
\hline Acetone & WG & $\begin{array}{c}\mathrm{G} \\
\text { (11) }\end{array}$ & $\begin{array}{c}G \\
(13)\end{array}$ & WG & $\mathrm{I} / \mathrm{A}$ & A & I & A & $\mathrm{P}$ \\
\hline THF & $\begin{array}{c}\text { G } \\
(8) \\
\end{array}$ & $\begin{array}{c}\text { G } \\
\text { (11) }\end{array}$ & A & $\begin{array}{l}\text { G } \\
(9) \\
\end{array}$ & $\mathrm{I} / \mathrm{A}$ & $\begin{array}{l}\text { G } \\
(9) \\
\end{array}$ & I & $\mathrm{Pc}$ & $\mathrm{Pc}$ \\
\hline DME & A & $\begin{array}{c}G \\
(7)\end{array}$ & I & WG & WG & A & $\mathrm{P}$ & A & $\mathrm{Pc}$ \\
\hline $\mathrm{CH}_{3} \mathrm{CN}$ & $\begin{array}{c}\text { G } \\
(8) \\
\end{array}$ & $\begin{array}{c}\text { G } \\
\text { (4) }\end{array}$ & WG & WG & $\begin{array}{l}\text { G } \\
\text { (6) }\end{array}$ & $\begin{array}{l}\text { G } \\
\text { (7) }\end{array}$ & $\begin{array}{l}\text { G } \\
\text { (7) }\end{array}$ & A & $\begin{array}{c}\mathrm{G} \\
(12)\end{array}$ \\
\hline $\mathrm{CH}_{2} \mathrm{Cl}_{2}$ & $\begin{array}{c}\text { G } \\
(8)\end{array}$ & $\begin{array}{c}G \\
\text { (11) }\end{array}$ & I & $\begin{array}{l}\text { G } \\
(9)\end{array}$ & WG & $\begin{array}{l}\text { G } \\
(9)\end{array}$ & $\begin{array}{c}G \\
(12) \\
\end{array}$ & $\mathrm{Pc}$ & $\mathrm{Pc}$ \\
\hline $\mathrm{CHCl}_{3}$ & $\begin{array}{c}\text { G } \\
(8) \\
\end{array}$ & $\begin{array}{c}\mathrm{G} \\
\text { (11) }\end{array}$ & I & $\begin{array}{l}\text { G } \\
\text { (9) }\end{array}$ & WG & $\begin{array}{l}\text { G } \\
\text { (9) }\end{array}$ & $\begin{array}{c}\mathrm{G} \\
(12) \\
\end{array}$ & WG & $\mathrm{Pc}$ \\
\hline Dioxane & WG & $\begin{array}{c}\text { G } \\
\text { (11) }\end{array}$ & A & $\begin{array}{c}G \\
(9) \\
\end{array}$ & WG & WG & $\begin{array}{c}G \\
(12) \\
\end{array}$ & $\mathrm{Pc}$ & $\mathrm{Pc}$ \\
\hline Cyclohexane & WG & $\mathrm{A} / \mathrm{Pc}$ & A & $\mathrm{A} / \mathrm{P}$ & A & $\begin{array}{l}\text { G } \\
(9)\end{array}$ & $\mathrm{P}$ & $\mathrm{Pc}$ & $\mathrm{Pc}$ \\
\hline Toluene & $\begin{array}{c}\text { G } \\
(8)\end{array}$ & $\begin{array}{l}\text { G } \\
(9)\end{array}$ & $\mathrm{Pc}$ & WG & $\begin{array}{c}G \\
(8)\end{array}$ & $\begin{array}{l}\text { G } \\
(6)\end{array}$ & $\begin{array}{c}\mathrm{G} \\
(10)\end{array}$ & WG & $\mathrm{Pc}$ \\
\hline
\end{tabular}

[a] Minimum gel concentration $(\mathrm{mM})$ in parentheses. [b] $\mathrm{G}=$ gel, $\mathrm{WG}=$ weak gel, $\mathrm{P}=$ precipitate, $\mathrm{Pc}=$ colloidal, $\mathrm{I}=$ insoluble, $\mathrm{A}=$ aggregates.

If the gelation capabilities of the compounds that present different alkyl chains on both ends are considered (compounds 6-12) it can be observed again than in apolar solvents the presence of short $C_{3}$ chains is not favorable for gel formation. For example, compounds 6, 11 and 12 are no capable of gel formation in toluene. The only compound in the series that contains $\mathrm{C}_{3}$ end chains and forms gels in solvents of low polarity is 8 which presents a $C_{12}$ chain that would compensate for the presence of the $\mathrm{C}_{3}$ chain on the other end. The data in Table 1 in general suggest that the compounds with similar alkyl chains on both ends are better gelators. For example, in acetone proper gels are only formed by compounds $5\left(\mathrm{C}_{6}\right.$ chains on both ends) and 6 ( $\mathrm{C}_{3}$ chains) and weak gels are formed by compound $4\left(\mathrm{C}_{12}\right.$ chains $)$ and $7\left(\mathrm{C}_{12}, \mathrm{C}_{6}\right.$ chains $)$. All the other compounds, which present dissimilar alkyl chains on both ends, do not form gels in acetone. These results suggest that in compounds with similar chain ends the interactions among the apolar moieties are strengthened as compared to the case of unsymmetrical compounds favoring the formation of gels.
In order to asses in more detail the role played by the aliphatic end groups in gelation, the replacement of one of the alkyl tails by an aromatic fragment was studied. In general, the substitution of alkyl moieties by aromatic moieties had a significant effect on the gelation behavior. For example, compound $5\left(\mathrm{C}_{6}, \mathrm{C}_{6}\right)$ forms gels in toluene but replacement of one $\mathrm{C}_{6}$ moiety by a phenyl or 4nitrophenyl (compounds $\mathbf{1 5}$ and $\mathbf{1 6}$ respectively) gives place to insoluble materials in this solvent. A similar tendency can be observed for compound $4\left(\mathrm{C}_{12}, \mathrm{C}_{12}\right)$ which is a good gelator in toluene but is transformed to a weak gelator in the case of compound $\mathbf{1 7}$ and to insoluble species in the case of 18. Clearly, these results indicate that in apolar solvents the aliphatic moieties play a relevant role for the formation of fibrillar structures which can not be paralleled with the use of aromatic moieties. Most likely aliphatic moieties provide to this family of molecules with more intense intermolecular interactions and a better packing capability as compared to analogous molecules with aromatic end groups. Indeed, compounds bearing two aromatic end-groups (i.e. compound 19) failed to form gels.

It is interesting to note that in a solvent of intermediate polarity such as THF compound $6\left(\mathrm{C}_{3}, \mathrm{C}_{3}\right)$ is not a gelator but its aromatic analogue with one phenyl end group (13) is capable of forming gels. This fact could be the result of improved solvation of phenyl moieties as compared to $\mathrm{C}_{3}$ units which would avoid precipitation of the aggregates. Finally, the more polar 4-nitrophenyl analogue (compound 14) does not form gels in the range of solvents studied.

Spectroscopic studies. FT-IR spectroscopy is a useful technique to investigate the secondary structure of peptides and proteins. ${ }^{[14]}$ For all the studied dialkyl compounds (4-12) the amide I band appeared at $1625 \mathrm{~cm}^{-1}$, what is typical for the strong $\mathrm{H}$-bonding of $\beta$-sheet secondary structure. Moreover, a weak band appeared at $1695 \mathrm{~cm}^{-1}$ indicating a high content of antiparallel $\beta$-sheet organization, in agreement with our previous results on compound $\mathbf{4}$ (see for instance Figure 1 for compound $\mathbf{5}$ and Supporting Information). It is noteworthy that FT-IR spectra of dried gels of compounds with aromatic end units such as compounds $\mathbf{1 5}$ and $\mathbf{1 7}$ showed the presence of a broad absorption band in the amide I region, with several overlapping peaks revealing not only an antiparallel $\beta$-sheet organization $\left(1698 \mathrm{~cm}^{-1}\right)$ but also other randomly organized assemblies (1682, 1668, $1650 \mathrm{~cm}^{-1}$ (see Supporting Information). This indicates that replacement of one of the alkyl units by a phenyl moiety generates weaker intermolecular interactions between aromatic and alkyl groups in the antiparallel arrangement as compared to those found in the compounds with two alkyl groups. In this way, the clear preference for the antiparallel arrangement found in compounds 4-12 is lost in the analogues with aromatic units 13-18 which would present also other aggregation modes including a parallel $\beta$-sheet disposition among them (see Figure 2).

Circular Dichroism was also used to support the formation of $\beta$ sheet type aggregates. ${ }^{[15]}$ Solid state spectra of xerogels were recorded and, in all the cases, a pattern typical for this arrangement was observed; a negative band with a maximum at ca. $220 \mathrm{~nm}$, and crossing zero at ca. $210 \mathrm{~nm}$, and in some cases a positive lobe at $195 \mathrm{~nm}$ (see for instance Figure 3 for compound 5 and Supporting Information). 


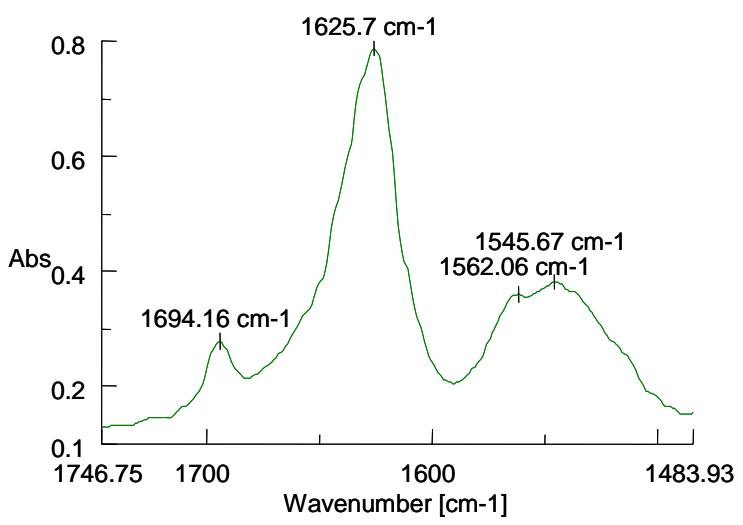

Figure 1. FT-IR of the amide $\mathrm{C}=\mathrm{O}$ region of xerogel of compound $\mathbf{5}$<smiles>CCCCCCNC(=O)C(C)NC(=O)CNC(=O)CNC(=O)CNC(=O)CNC(=O)CNC(=O)CNC(=O)CNC(=O)c1ccccc1</smiles><smiles>CCCCCCNC(=O)C(C)NC(=O)CNC(=O)CNC(=O)CNC(=O)CNC(=O)CNC(=O)CNC(=O)c1ccccc1OC</smiles>

parallel $\beta$-sheet

Figure 2. Proposed antiparallel and parallel arrangements for compound 15.

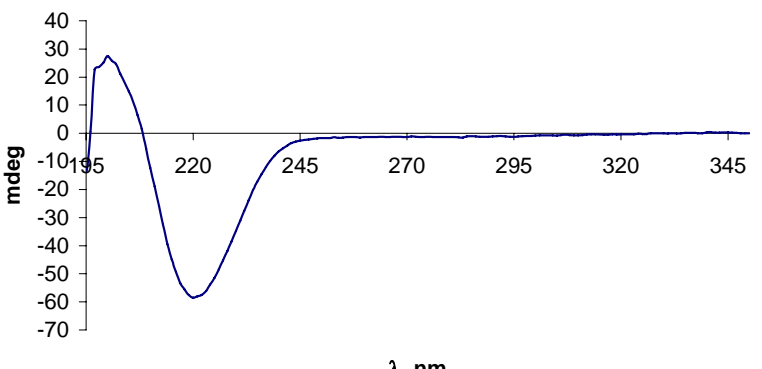

Figure 3. CD spectrum of a xerogel of compound 5 (from a toluene gel).

X-Ray powder diffraction. Wide-angle X-ray diffraction (WAXD) spectra of the xerogels were in good agreement with the proposed $\beta$-sheet arrangement. In all the cases, a low angle sharp peak corresponding approximately to a calculated distance for a fully extended molecule was obtained. For example, for compound 5, the WAXD data of xerogels obtained from different solvents provided in all the cases peaks corresponding to a periodicity of 30 $\AA$ which fits nicely with the calculated distance for an extended molecule. Additionally, in all the cases, peaks assigned to a periodic distance of $4.4 \AA$ were found that can be ascribed to extended two-dimensional layers of $\beta$-sheets that stack parallel on top of each other (see Figure 4 and Supporting Information for other compounds).

For a given compound, there were not important differences in the position of the diffraction peaks between different solvents. This fact reveals that although macroscopic properties such as solubility or gelation efficiency are strongly solvent dependent, the solvent has a limited effect in the organization at the molecular level. Only some subtle differences were observed for the low-angle peaks related, probably, with a different degree of mobility of the tails. Higher angle peaks, corresponding to shorter distances in the microcrystalline structure, were sometimes absent, especially in xerogels from apolar solvents, which also showed broader bands than in polar ones. This is probably due to a higher extent of tail mobility that could provoke the presence of some folded segments within the chain.
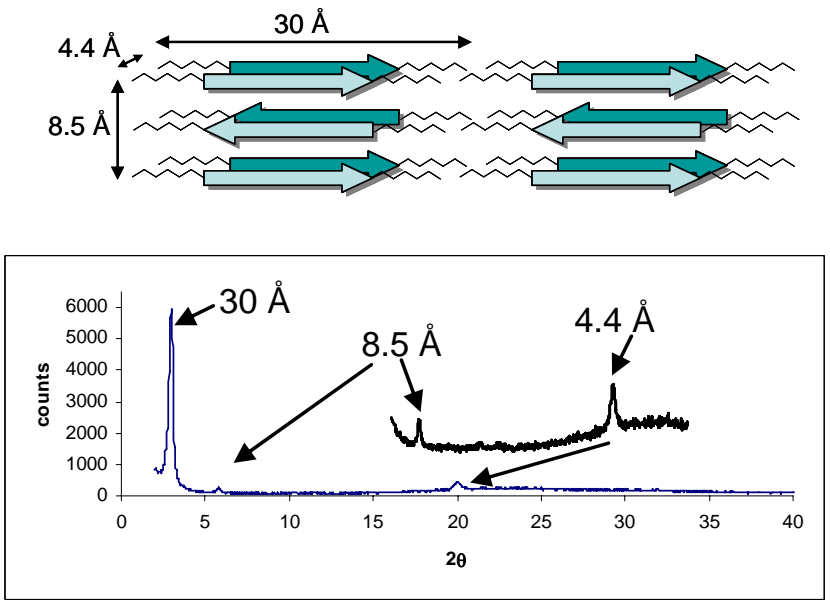

Figure 4. Proposed packing model (top) and WAXD pattern (bottom) for xerogels of compound 5 .

In natural silk fibers, the antiparallel organization is achieved through an intramolecular turn of the polypeptidic chain being the repeating distance corresponding to the H-bonding direction of ca. $9.4 \AA \AA^{[16]}$ In our case, where this turn is not present, we found two different situations: i) compounds bearing $\mathrm{C}_{12}$ tails, which showed a spacing of ca. $11 \AA$, and ii) compounds with shorter length tails, that presented shorter spacing $(8.5 \AA)$. In the first case, the greater chain mobility of the longest tails could explain the observed larger spacing, while in the second shorter tails resulted in a more compact packing.

At a higher level of organization, two different packing models may be proposed for the arrangement of the antiparallel $\beta$-sheets, namely, head-to-head or head-to-tail (see Scheme 3). For symmetrically substituted compounds, only the head-to-tail packing fits with the observed low angle diffraction peaks, coincident with the fully extended molecular dimension. A headto-head packing would produce larger repeating distances than those obtained experimentally. Similarly, in the case of, unsymmetrically substituted compounds, head-to-tail packing also fits with the experimental data and a head-to-head packing seems less likely because it would cause kinks and folds in the chains with the result of a loss of packing efficiency. 


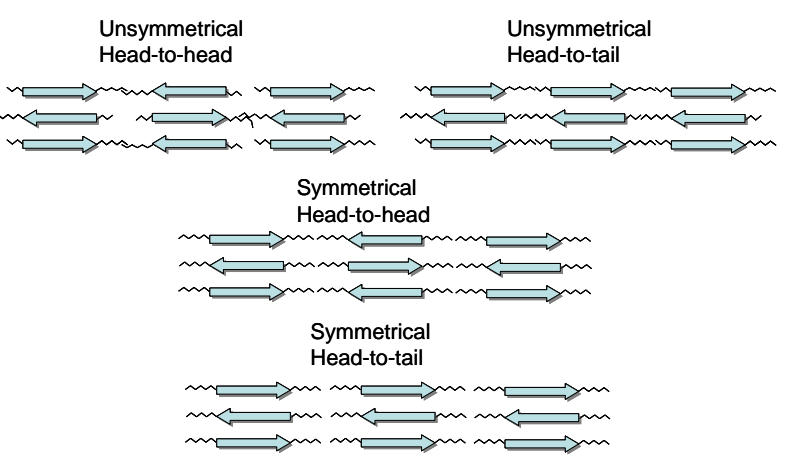

Scheme 3

Electron microscopy studies. The microscopic aspect of the gels and fibrillar aggregates obtained was studied by scanning electron microscopy. For this purpose aggregates were dried and the xerogels were investigated. These compounds presented a high tendency to form fibrillar architectures. Fibers and fibrils were observed in most of the cases with differences in length, stiffness and branching degree, revealing that these compounds have a great tendency to form elongated objects (Figures 5, 6 and 7). Some of them further entangled to form networks whereas others merged into rigid and long ribbons, or even fused into globular objects with membrane-like aspect.

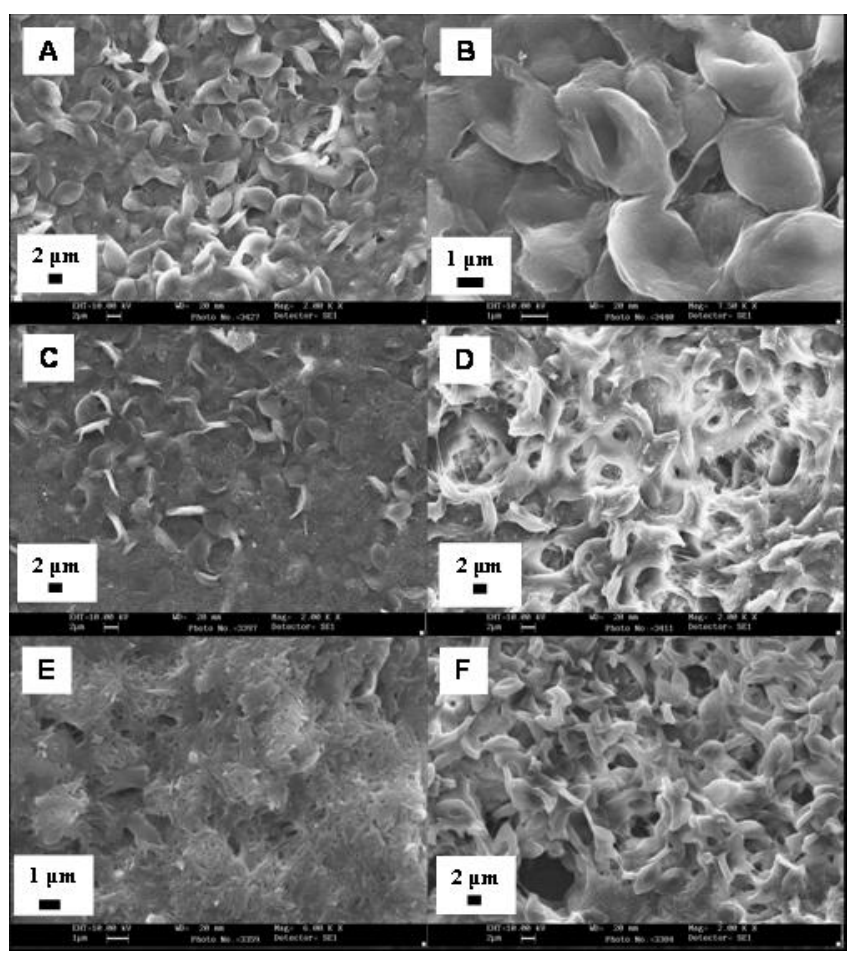

Figure 5. SEM images of xerogels from compounds 5 (A,B), 6 (C), 8 (D), $10(E)$ and 12 (F) gels in toluene.

Although WAXD studies have revealed that all the studied molecules present, basically, the same organization at the molecular level, the gel network showed a diversity of morphologies depending mainly on the solvent. For instance, the network of xerogels obtained from toluene is formed by tiny fibrils of less than $100 \mathrm{~nm}$ width, that are fused forming bags of micrometer size that were probably filled by solvent in the original gels (Figure 5). ${ }^{[13]}$ Even for compounds 6 and 12, that did not form strong gels, a similar morphology was observed with only subtle differences at the microscopic level. In difference, xerogels from acetonitrile (Figure 6) revealed a network made by very long and thin fibers, with several hundreds of nanometers in width and tens of micrometers in length, that in some cases appeared highly aligned (5 and 10) whereas in other cases showed a higher tendency for coiling and cross-linking (7, 8, 9 and 12). For xerogels prepared from alcohols (Figure 7) very long and thin fibers were also observed in general. However in the case of compound $\mathbf{1 1}$ a different aspect was observed in methanol. In this case fibers were significantly shorter and, in consequence, the formation of a network was not complete and isolated aggregates were formed instead of a strong gel. The xerogel from compound 8 was also different but, in this case, a higher degree of cross-linking could be observed in agreement with the formation of a strong gel in that solvent.

From this behavior, it may be concluded that, for those compounds that formed gels, the nature of the side chains does not seem to affect significantly to the microscopic aspect of the xerogel for a given solvent being the formation of fibrillar networks a general trend. Only in the cases where a strong gel was not formed, namely aggregates or precipitates being formed instead, different morphologies were observed.

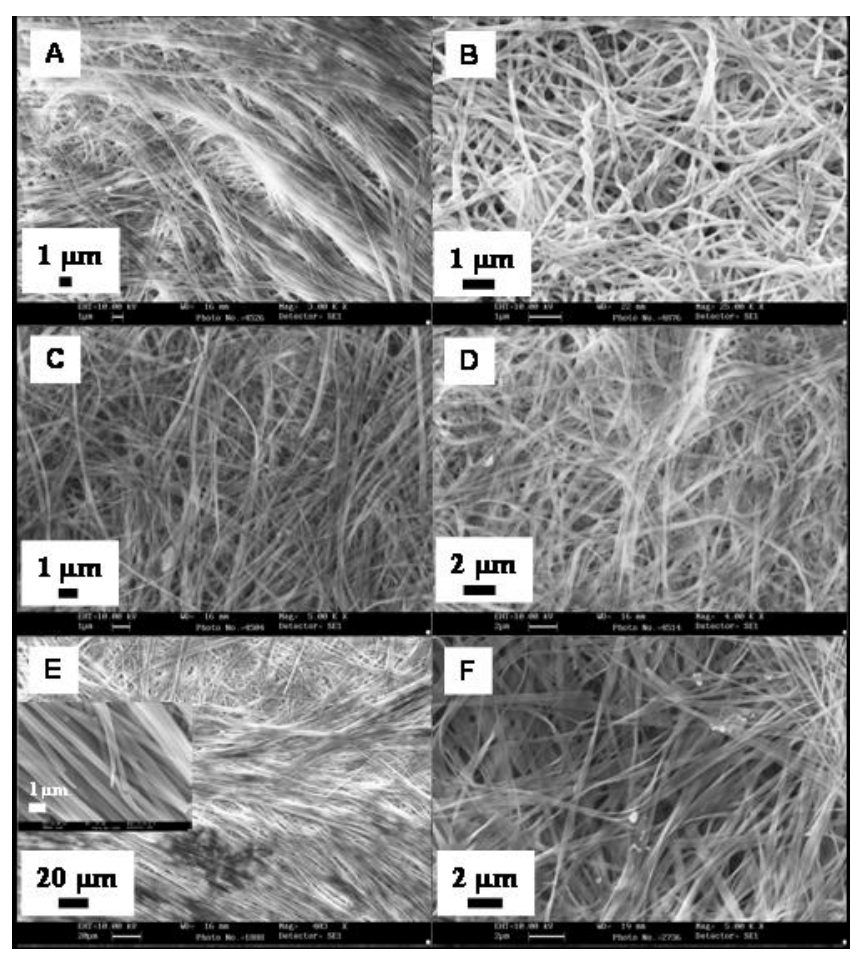

Figure 6. SEM images of xerogels from compounds 5 (A), 7 (B), 8 (C), 9 (D), $10(\mathrm{E})$ and $12(\mathrm{~F})$ gels in acetonitrile.

Taking into account all the structural information discussed above and the fact that all these compounds, despite of showing different specific morphologies, assemble into fibrillar aggregates, we may propose a model for their hierarchical organization into microscopic size fibers. In a first level of organization, molecular entities assemble to form an antiparallel $\beta$-sheet secondary structure, with a vague influence of the length of the alkyl chains. This extended sheets stack into parallel layers separated by $4.4 \AA$ in all the cases. These layers have a preferential one-dimensional growth that produces fibers directed by the formation of H-bonds parallel to their axe. This arrangement is known as the cross- $\beta$ 
structure and is typical for amyloid-like fibrils and some silk fibroins (Figure 8). ${ }^{[8,18]}$

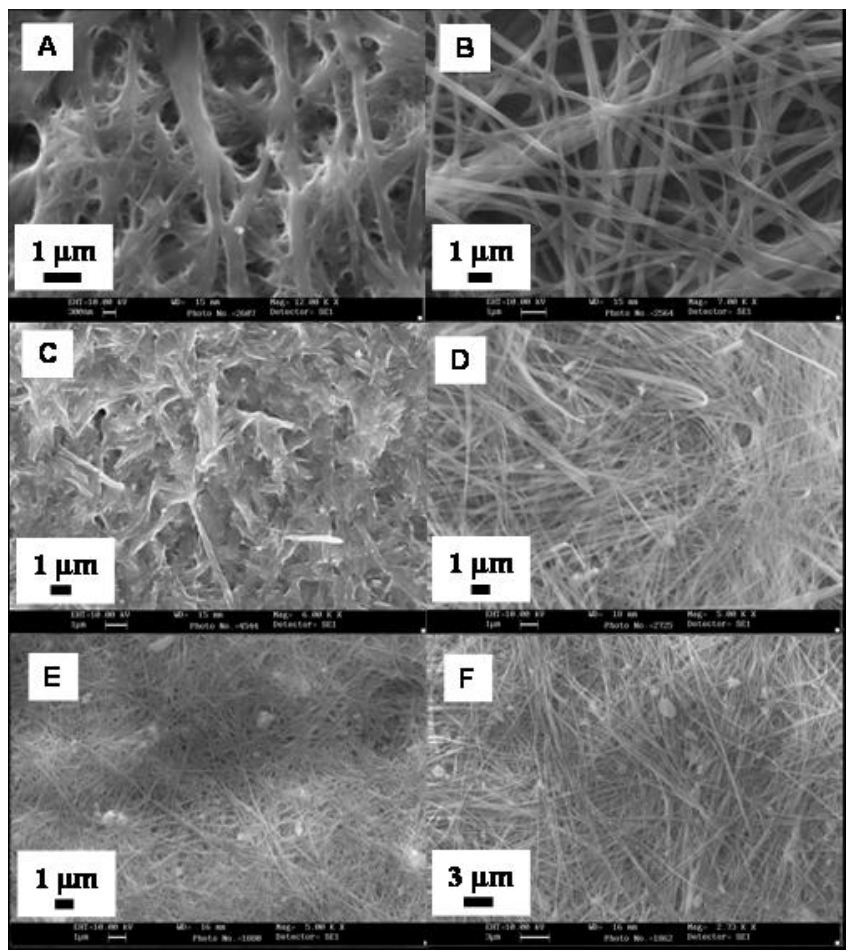

Figure 7. SEM images of xerogels from compounds 8 (A), 10 (B), 11 (C) and 12 (D) gels in methanol and $5(\mathrm{E})$ and 8 (F) in 2-propanol .

The potential influence of side groups in the self-assembly of oligopeptides and its effect on the fiber packing has been reported. ${ }^{[19]}$ In our case, as in other reported, it seems reasonable that the strongest interaction, H-bonding, runs parallel to the fiber axe, and that interactions between tails have a smaller contribution to the resulting elongated objects. ${ }^{[20]}$ This model would explain why fibrillar aggregates are always found for those compounds that formed gels, independently of the chain length. Thus, the effectiveness of the interaction between tails would affect on the thickness of the fibers, and in some extend on the fiber length. For instance, packing of symmetrical tails would lead to a more stable situation than for unsymmetrical ones, where intercalation or folding may produce packing mistakes and kinks.

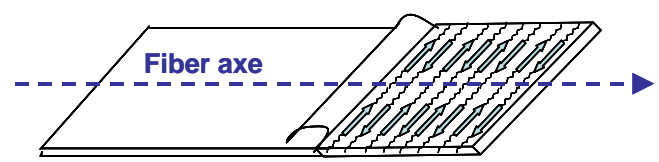

cross $\beta$ structure

Figure 8. Propossed cross $\beta$ packing.

\section{Conclusion}

We have studied in detail the aggregation behavior of a series of silk-inspired low molecular weight compounds containing a $\beta$ sheet-like H-bonding core and apolar end groups. It has been shown that these molecules present a high tendency to form fibrillar networks that in many cases produced gels. The results have provided useful information on the role played by the apolar alkyl chains in the self-assembly. It has been noticed than the length of the apolar moiety can affect directly to the gelation capabilities of these molecules and this behavior can be associated to factors such as solubility and intermolecular interactions. The presence of similar alkyl chains on both ends of the molecule has been shown to improve the gelation properties, most likely due to a favorable packing of the $\beta$-sheet like stacks. Structural studies of the aggregation at the molecular level with FT-IR, circular dichroism and WAXD revealed that all the alkyl terminated gelators present an antiparallel $\beta$-sheet type arrangement. However, replacement of alkyl by aromatic end groups results in the formation of materials where different structural motifs coexist (antiparallel and parallel $\beta$-sheet for example). Having in mind that strong H-bonding interactions are possible both in the parallel and antiparallel arrangements, these results indicate that alkyl groups play a key role in the observed antiparallel structures. This fact can be ascribed to factors such as packing efficiency, solvophobic effects and favorable van der Waals interactions. Finally, a variety of microscopic morphologies associated with really small changes in molecular structure and solvent have been observed in the SEM study of the xerogels.

Overall the results reveal that this is a family of versatile gelators because the fine tuning of their structure permits the formation of gels is a broad range of solvents of different polarity. Identically, the microscopic aspect of the material can also be regulated by simple structural changes and this property is interesting in fields associated to nanofabrication. Most interestingly, the fidelity found for the antiparallel $\beta$-sheet motif opens the door for the use of this tetrapeptidic structure as scaffold for the construction of highly ordered functional materials with application, for example, in materials science and catalysis.

\section{Experimental Section}

Synthesis. General procedure for compounds 1a-c: Benzyloxycarbonyl-Glycyl- $L$ Alanine $(3.57 \mathrm{mmol})$ dissolved in $80 \mathrm{~mL}$ of freshly dry DME was placed in a roundbottomed flask with a stirrer, and immersed in an ice bath. Dicyclohexylcarbodiimide (DCC) $(4.6 \mathrm{mmole})$ dissolved in $100 \mathrm{~mL}$ of DME was added dropwise to the solution during a period of $1 \mathrm{~h}$, and the mixture was kept at stirring for $2 \mathrm{~h}$. Then, amine (3.5 mmole) dissolved in dry DME was added slowly, and the mixture was shifted to room temperature by over night stirring. Afterward, the white suspension was filtered and solvent was evaporated under vacuum. The product was purified by column chromatogarphy on silica gel using $\left(\mathrm{CH}_{2} \mathrm{Cl}_{2}: \mathrm{MeOH}\right)$ as eluent.

N-propyl-(N'-benzyloxycarbonyl-glycyl)-L-alanine amide (1a). White solid (62\% yield). mp: $117-120{ }^{\circ} \mathrm{C} . \mathrm{R}_{\mathrm{f}}=0.59\left(\mathrm{CH}_{2} \mathrm{Cl}_{2}: \mathrm{MeOH}, 96: 4\right) .{ }^{1} \mathrm{H}$ NMR $\left(300 \mathrm{MHz}, 30{ }^{\circ} \mathrm{C}\right.$, DMSO- $\left.\mathrm{d}_{6}\right) \delta 0.78(\mathrm{t}, \mathrm{J}=7.2 \mathrm{~Hz}, 3 \mathrm{H}), 1.16(\mathrm{~d}, \mathrm{~J}=6.9 \mathrm{~Hz}, 3 \mathrm{H}), 1.30(\mathrm{~m}, 2 \mathrm{H}), 2.93(\mathrm{q}$, $\mathrm{J}=6.6 \mathrm{~Hz}, 2 \mathrm{H}), 3.61(\mathrm{~d}, \mathrm{~J}=5.7 \mathrm{~Hz}, 2 \mathrm{H}), 4.19(\mathrm{~m}, 1 \mathrm{H}), 5.01(\mathrm{~s}, 2 \mathrm{H}), 7.35(\mathrm{~s}, 5 \mathrm{H}), 7.41$ $(\mathrm{t}, \mathrm{J}=5.4 \mathrm{~Hz}, 1 \mathrm{H}), 7.80(\mathrm{~s}, 1 \mathrm{H}), 7.94(\mathrm{~d}, \mathrm{~J}=7.2 \mathrm{~Hz}, 1 \mathrm{H}) .{ }^{13} \mathrm{C}$ NMR $\left(75 \mathrm{MHz}, 30{ }^{\circ} \mathrm{C}\right.$, DMSO- $\left.\mathrm{d}_{6}\right) \delta 11.97,19.23,22.92,44.21,48.85,66.14,128.32,128.46,129.03$, 137.73, 157.21, 169.30, 172.55. IR cm ${ }^{-1} ; 3307,3268,2961,2850,1723,1691,1646$, 1542, 1267. HRMS (ESI-TOF, positive mode) $\mathrm{m} / \mathrm{z}$ exp $[\mathrm{M}+\mathrm{Na}]+$ calcd. for $\mathrm{C}_{16} \mathrm{H}_{23} \mathrm{~N}_{3} \mathrm{O}_{4} \mathrm{Na}+, 344.1581$ found, $344.1587[\mathrm{M}+\mathrm{Na}]^{+}, 665.21[2 \mathrm{M}+\mathrm{Na}]^{+},(\Delta=1.7$ ppm).

N-hexyl-(N'-benzyloxycarbonyl-glycyl)-L-alanine amide (1b). White solid (78\% yield). mp: $115-117{ }^{\circ} \mathrm{C} . \mathrm{R}_{\mathrm{f}}=0.63\left(\mathrm{CH}_{2} \mathrm{Cl}_{2}: \mathrm{MeOH}, 96: 4\right) .{ }^{1} \mathrm{H} \mathrm{NMR}\left(300 \mathrm{MHz}, 30^{\circ} \mathrm{C}\right.$, DMSO- $\left.\mathrm{d}_{6}\right) \delta 0.81(\mathrm{t}, \mathrm{J}=6.3 \mathrm{~Hz}, 3 \mathrm{H}), 1.16(\mathrm{~m}, 9 \mathrm{H}), 1.34(\mathrm{t}, \mathrm{J}=6.3 \mathrm{~Hz}, 2 \mathrm{H}), 2.97(\mathrm{q}, \mathrm{J}$ $=6.3 \mathrm{~Hz}, 2 \mathrm{H}), 3.61(\mathrm{~d}, \mathrm{~J}=5.7 \mathrm{~Hz}, 2 \mathrm{H}), 4.21(\mathrm{~m}, 1 \mathrm{H}), 5.01(\mathrm{~s}, 2 \mathrm{H}), 7.35(\mathrm{~s}, 5 \mathrm{H}), 7.43$ $(\mathrm{t}, \mathrm{J}=5.7 \mathrm{~Hz}, 1 \mathrm{H}), 7.77(\mathrm{~s}, 1 \mathrm{H}), 7.93(\mathrm{~d}, \mathrm{~J}=7.5 \mathrm{~Hz}, 1 \mathrm{H}) .{ }^{13} \mathrm{C} \mathrm{NMR}\left(75 \mathrm{MHz}, 30{ }^{\circ} \mathrm{C}\right.$, DMSO- $\left.d_{6}\right) \delta 14.55,19.20,22.68,26.61,29.60,31.60,39.18,44.21,48.83,66.13$, 128.31, 128.46, 129.02, 137.72, 157.21, 169.29, 172.47. IR cm${ }^{-1} ; 3314,3079,2930$, $2857,1736,1674,1653,1536,1256$. HRMS (ESI-TOF, positive mode) $\mathrm{m} / \mathrm{z}$ exp [M + $\mathrm{Na}]^{+}$calcd for $\mathrm{C}_{19} \mathrm{H}_{29} \mathrm{~N}_{3} \mathrm{O}_{4} \mathrm{Na}^{+}, 386.2056$; found, $386.2049[\mathrm{M}+\mathrm{Na}]^{+}, 749.32[2 \mathrm{M}+$ $\mathrm{Na}]^{+}, 364.22[\mathrm{M}+\mathrm{H}]^{+},(\Delta=1.8 \mathrm{ppm})$. 
N-docecyl-(N'-benzyloxycarbonyl-glycyl)-L-alanine amide (1c). White solid (92\% yield). mp: $121-124{ }^{\circ} \mathrm{C} . \mathrm{R}_{\mathrm{f}}=0.68\left(\mathrm{CH}_{2} \mathrm{Cl}_{2}: \mathrm{MeOH}, 90: 10\right) .{ }^{1} \mathrm{H}$ NMR $\left(300 \mathrm{MHz}, 30^{\circ} \mathrm{C}\right.$ DMSO- $\left.\mathrm{d}_{6}\right) \delta 0.81(\mathrm{t}, \mathrm{J}=6.3 \mathrm{~Hz}, 3 \mathrm{H}), 1.15-1.25(\mathrm{~m}, 21 \mathrm{H}), 1.34(\mathrm{t}, \mathrm{J}=5.7 \mathrm{~Hz}, 2 \mathrm{H})$, $2.97(\mathrm{q}, \mathrm{J}=6.3 \mathrm{~Hz}, 2 \mathrm{H}), 3.60(\mathrm{~d}, \mathrm{~J}=6 \mathrm{~Hz}, 2 \mathrm{H}), 4.19(\mathrm{~m}, 1 \mathrm{H}), 5.01(\mathrm{~s}, 2 \mathrm{H}), 7.33(\mathrm{~s}$, $5 \mathrm{H}), 7.44(\mathrm{t}, \mathrm{J}=6.0 \mathrm{~Hz}, 1 \mathrm{H}), 7.76(\mathrm{~s}, 1 \mathrm{H}), 7.77(\mathrm{~d}, \mathrm{~J}=7.5 \mathrm{~Hz}, 1 \mathrm{H}) .{ }^{13} \mathrm{C}$ NMR $(75$ $\mathrm{MHz}, 30^{\circ} \mathrm{C}$, DMSO- $\left.\mathrm{d}_{6}\right) \delta 14.62,19.27,22.76,26.97,2 \mathrm{C}(29.37), 5 \mathrm{C}(29.66), 31.96$, $39.18,44.23,48.81,66.13,128.31,128.44,129.01,137.72,157.19,169.25,172.42$. $\mathrm{IR} \mathrm{cm}^{-1}$; 3321, 3070, 2921, 2850, 1726, 1687, 1653, 1546, 1272. HRMS (ESI-TOF, positive mode) $\mathrm{m} / \mathrm{z}$ exp $[\mathrm{M}+\mathrm{Na}]^{+}$calcd for $\mathrm{C}_{25} \mathrm{H}_{41} \mathrm{~N}_{3} \mathrm{O}_{4} \mathrm{Na}^{+}$, 470.2995; found, $470.3002[\mathrm{M}+\mathrm{Na}]^{+} 917.4327[2 \mathrm{M}+\mathrm{Na}]^{+}, 448.3202[\mathrm{M}+\mathrm{Na}]^{+},(\Delta=1.4 \mathrm{ppm})$.

General Procedure for compounds 2a-c: Compound 1 (1.43 mmoles) was dissolved in $30 \mathrm{~mL}$ of methanol containing $50 \mathrm{mg}$ of palladium $5 \mathrm{wt} \%$ on activated carbon in a two necked-round bottom flask. Then a balloon filled with hydrogen gas was connected to one neck of the flask and the system was saturated with hydrogen by slightly opening and closing of second neck to remove air. After complete deprotection, the solution was filtered through celite and the filtrate was evaporated under vacuum. The product was purified through silica column using mixtures of $\mathrm{CH}_{2} \mathrm{Cl}_{2}: \mathrm{MeOH}$ as eluent.

N-propyl-(N'-Glycyl)-L-alanine amide (2a). White solid (Yield: $98 \%$ ). mp: $290{ }^{\circ} \mathrm{C}$ dec. $\mathrm{R}_{\mathrm{f}}=0.37\left(\mathrm{MeOH}: \mathrm{CH}_{2} \mathrm{Cl}_{2}, 25: 75\right) .{ }^{1} \mathrm{H}$ NMR $\left(300 \mathrm{MHz}, 30^{\circ} \mathrm{C}\right.$, DMSO- $\left.\mathrm{d}_{6}\right) \delta$ $0.83(\mathrm{t}, \mathrm{J}=7.2 \mathrm{~Hz}, 3 \mathrm{H}), 1.17(\mathrm{~d}, \mathrm{~J}=7.5 \mathrm{~Hz}, 3 \mathrm{H}), 1.35-1.41(\mathrm{~m}, 2 \mathrm{H}), 2.99(\mathrm{~m}, 2 \mathrm{H})$, $3.10(\mathrm{~s}, 2 \mathrm{H}) 4.55(\mathrm{~m}, 1 \mathrm{H}), 7.90(\mathrm{~s}, 1 \mathrm{H}), 8.02(\mathrm{~d}, 1 \mathrm{H}) \cdot{ }^{13} \mathrm{C} \mathrm{NMR}\left(75 \mathrm{MHz}, 30{ }^{\circ} \mathrm{C}\right.$, DMSO- $\left.\mathrm{d}_{6}\right) \delta 11.96,19.70,22.93,39.36,44.93,48.46,172.46,172.63 . \mathrm{IR} \mathrm{cm} \mathrm{cm}^{-1} ; 3292$ $2967,2850,1646,1545,1458,1254$. HRMS (ESI-TOF, positive mode) $\mathrm{m} / \mathrm{z}$ exp [M + $\mathrm{Na}]^{+}$calcd for $\mathrm{C}_{8} \mathrm{H}_{17} \mathrm{~N}_{3} \mathrm{O}_{2} \mathrm{Na}^{+}, 210.1213$; found, $210.1176[\mathrm{M}+\mathrm{Na}]^{+}, 397.2142[2 \mathrm{M}+$ $\mathrm{Na}]^{+},(\Delta=19.0 \mathrm{ppm})$.

N-hexyl-(N'-Glycyl)- $\boldsymbol{L}$-alanine amide (2b). White solid (Yield: $97 \%)$. mp: $82-84{ }^{\circ} \mathrm{C}$ $\mathrm{R}_{\mathrm{f}}=0.42\left(\mathrm{MeOH}: \mathrm{CH}_{2} \mathrm{Cl}_{2}, 25: 75\right) .{ }^{1} \mathrm{H}$ NMR $\left(300 \mathrm{MHz}, 30^{\circ} \mathrm{C}, \mathrm{DMSO}-\mathrm{d}_{6}\right) \delta 0.82(\mathrm{t}$, $\mathrm{J}=6.6 \mathrm{~Hz}, 3 \mathrm{H}), 1.16(\mathrm{~m}, 11 \mathrm{H}), 1.34(\mathrm{t}, \mathrm{J}=6.6 \mathrm{~Hz}, 2 \mathrm{H}), 3.00(\mathrm{~m}, 2 \mathrm{H}), 3.03(\mathrm{~m}, 2 \mathrm{H})$ $4.24(\mathrm{~m}, 1 \mathrm{H}), 7.88(\mathrm{t}, \mathrm{J}=5.1 \mathrm{~Hz}, 1 \mathrm{H}), 8.02(\mathrm{~s}, 1 \mathrm{H}) .{ }^{13} \mathrm{C} \mathrm{NMR}\left(75 \mathrm{MHz}, 30{ }^{\circ} \mathrm{C}\right.$ DMSO-d6) $\delta 14.77,19.95,22.92,26.84,29.85,31.82,39.35,45.29,48.62,172.75$, 172.83. IR cm$~^{-1} ; 3283,2930,2853,1647,1511,1458,1251$. HRMS (ESI-TOF, positive mode) $\mathrm{m} / \mathrm{z}$ exp $[\mathrm{M}+\mathrm{Na}]^{+}$calcd for $\mathrm{C}_{11} \mathrm{H}_{23} \mathrm{~N}_{3} \mathrm{O}_{2} \mathrm{Na}^{+}, 252.1682$; found, $252.1639[\mathrm{M}+\mathrm{Na}]^{+}, 481.2881[2 \mathrm{M}+\mathrm{Na}]^{+},(\Delta=17.0 \mathrm{ppm})$.

N-dodecyl-(N'-Glycyl)-L-alanine amide (2c). White solid (Yield: $98 \%$ ). mp: $88-89$ ${ }^{\circ} \mathrm{C}$. Rf $=0.51\left(\mathrm{MeOH}: \mathrm{CH}_{2} \mathrm{Cl}_{2}, 25: 75\right) .{ }^{1} \mathrm{H}$ NMR $\left(300 \mathrm{MHz}, 30{ }^{\circ} \mathrm{C}\right.$, DMSO-d 6 ) $\delta$ $0.81(\mathrm{t}, \mathrm{J}=6.3 \mathrm{~Hz}, 3 \mathrm{H}), 1.17-1.23(\mathrm{~m}, 23 \mathrm{H}), 1.34(\mathrm{t}, \mathrm{J}=6.6 \mathrm{~Hz}, 2 \mathrm{H}), 2.97(\mathrm{~m}, 2 \mathrm{H})$, $3.11(\mathrm{~s}, 2 \mathrm{H}), 4.26(\mathrm{~m}, 1 \mathrm{H}), 7.91(\mathrm{t}, \mathrm{J}=5.7 \mathrm{~Hz}, 1 \mathrm{H}), 8.28(\mathrm{~d}, \mathrm{~J}=6.9 \mathrm{~Hz}, 1 \mathrm{H}) .{ }^{13} \mathrm{C}$ NMR $\left(75 \mathrm{MHz}, 30{ }^{\circ} \mathrm{C}\right.$, DMSO- $\left.\mathrm{d}_{6}\right) \delta 14.62,19.48,22.75,26.96,2 \mathrm{C}(29.37), 5 \mathrm{C}$ (29.65), 31.95, 39.15, 42.62, 48.81, 168.88, 172.28. IR cm $\mathrm{cm}^{-1}$ 3298, 2930, 2849, 1647 , 1561, 1459, 1248. HRMS (ESI-TOF, positive mode) $\mathrm{m} / \mathrm{z}$ exp $[\mathrm{M}+\mathrm{Na}]^{+}$calcd for $\mathrm{C}_{17} \mathrm{H}_{35} \mathrm{~N}_{3} \mathrm{O}_{2} \mathrm{Na}^{+}, 336.2621$; found, $336.2663[\mathrm{M}+\mathrm{Na}]^{+},(\Delta=10.0 \mathrm{ppm})$.

General Procedure for compounds 3a-c: Glycyl- $L$-Alanine ( $6.8 \mathrm{mmole})$ dissolved in $50 \mathrm{~mL}$ of $1 \mathrm{M} \mathrm{NaOH}$ was placed in a round-bottomed flask with an efficient magnetic stirrer. The flask was completely immersed in an ice bath and during reaction; stirrer was set in very rapid motion. To the solution, $13.6 \mathrm{mmol}$ of pure acyl chloride and 10 $\mathrm{mL}$ of $1 \mathrm{M} \mathrm{NaOH}$ were added dropwise at the same rate in such a way that $\mathrm{pH}$ of reaction mixture should not decrease below 10 . When the reaction was complete, the suspension was acidified carefully with $2 \mathrm{M} \mathrm{HCl}$. The residue obtained after filtration was extracted with petroleum ether to remove the fatty acid. The final dipeptide derivative was chromatographed on a silica gel column with $\mathrm{MeOH}: \mathrm{CH}_{2} \mathrm{Cl}_{2}$ mixtures as eluent.

Propanoyl-glycyl- $L$-alanine (3a). White solid (Yield: $82 \%$ ). mp: $104-107^{\circ} \mathrm{C} . \mathrm{R}_{\mathrm{f}}=$ 0.25 (MeOH: $\left.\mathrm{CH}_{2} \mathrm{Cl}_{2}, 10: 90\right)$. ${ }^{1} \mathrm{H}$ NMR $\left(300 \mathrm{MHz}, 30^{\circ} \mathrm{C}\right.$, DMSO- $\left.\mathrm{d}_{6}\right) \delta 0.94(\mathrm{t}, \mathrm{J}=$ $7.5 \mathrm{~Hz}, 3 \mathrm{H}), 1.22-1.25(\mathrm{~m}, 3 \mathrm{H}), 2.07(\mathrm{q}, \mathrm{J}=7.8 \mathrm{~Hz}, 2 \mathrm{H}), 3.66(\mathrm{~m}, 2 \mathrm{H}), 4.22(\mathrm{~m}, 1 \mathrm{H})$, $7.96(\mathrm{~d}, \mathrm{~J}=5.4 \mathrm{~Hz}, 1 \mathrm{H}), 8.07(\mathrm{~d}, \mathrm{~J}=7.2 \mathrm{~Hz}, 1 \mathrm{H}), 12.55$ (s broad, $1 \mathrm{H}) .{ }^{13} \mathrm{C}$ NMR $(75$ $\mathrm{MHz}, 30{ }^{\circ} \mathrm{C}$, DMSO-d6) $\delta 10.29,17.80,17.83,28.80,42.15,47.93,47.99,169.30$, 173.72, 174.49. IR cm $\mathrm{cm}^{-1} ; 3386,3273,3098,2984,2531,1743,1633,1577,1210$ HRMS (ESI-TOF, positive mode) $\mathrm{m} / \mathrm{z}$ exp $[\mathrm{M}+\mathrm{Na}]^{+}$calcd for $\mathrm{C}_{8} \mathrm{H}_{14} \mathrm{~N}_{2} \mathrm{O}_{4} \mathrm{Na}^{+}$, 225.0846; found, $225.0861[\mathrm{M}+\mathrm{Na}]^{+},(\Delta=6.6 \mathrm{ppm})$.

Hexanoyl-glycyl-L-alanine (3b). White solid (Yield: $89 \%$ ). mp: $\quad 125-127{ }^{\circ} \mathrm{C} . \quad{ }^{1} \mathrm{H}$ NMR $\left(300 \mathrm{MHz}, 30{ }^{\circ} \mathrm{C}, \mathrm{DMSO}_{-} \mathrm{d}_{6}\right) \delta 0.81(\mathrm{t}, \mathrm{J}=6.6 \mathrm{~Hz}, 3 \mathrm{H}), 1.21-1.25(\mathrm{~m}, 7 \mathrm{H}), 1.45$ $(\mathrm{q}, \mathrm{J}=7.2 \mathrm{~Hz}, 2 \mathrm{H}), 2.07(\mathrm{t}, \mathrm{J}=7.5 \mathrm{~Hz}, 2 \mathrm{H}), 3.66(\mathrm{~m}, 2 \mathrm{H}), 4.16(\mathrm{~m}, 1 \mathrm{H}), 7.95(\mathrm{t}, \mathrm{J}=$ $5.4 \mathrm{~Hz}, 1 \mathrm{H}), 8.05(\mathrm{~d}, \mathrm{~J}=7.5 \mathrm{~Hz}, 1 \mathrm{H}), 12.54(\mathrm{~s}, \mathrm{br}, 1 \mathrm{H}) .{ }^{13} \mathrm{C} \mathrm{NMR}\left(75 \mathrm{MHz}, 30{ }^{\circ} \mathrm{C}\right.$, DMSO-d6) $\delta$ 14.52, 18.00, 22.55, 25.52, 31.55, 35.82, 42.32, 48.12, 169.44, 173.20, 174.63. IR cm ${ }^{-1}$; 3292, 3102, 2859, 2570, 1734, 1641, 1570, 1209. HRMS (ESI-TOF, positive mode) $\mathrm{m} / \mathrm{z}$ exp $[\mathrm{M}+\mathrm{Na}]^{+}$calcd for $\mathrm{C}_{11} \mathrm{H}_{20} \mathrm{~N}_{2} \mathrm{O}_{4} \mathrm{Na}^{+}, 267.1315$; found, $267.1324[\mathrm{M}+\mathrm{Na}]^{+}, 511.2747[2 \mathrm{M}+\mathrm{Na}]^{+},(\Delta=3.3 \mathrm{ppm})$

Dodecanoyl-glycyl-L-alanine (3c). White solid (Yield: 94\%). mp: $133-135{ }^{\circ} \mathrm{C} .{ }^{1} \mathrm{H}$ NMR $\left(300 \mathrm{MHz}, 30^{\circ} \mathrm{C}\right.$, DMSO- $\left.\mathrm{d}_{6}\right) \delta 0.81(\mathrm{t}, \mathrm{J}=6.0 \mathrm{~Hz}, 3 \mathrm{H}), 1.20-1.25(\mathrm{~m}, 19 \mathrm{H})$ $1.46(\mathrm{~s}, 2 \mathrm{H}), 2.06(\mathrm{t}, \mathrm{J}=7.2 \mathrm{~Hz}, 2 \mathrm{H}), 3.62(\mathrm{~m}, 2 \mathrm{H}), 4.19(\mathrm{~m}, 1 \mathrm{H}), 7.91(\mathrm{t}, \mathrm{J}=5.4 \mathrm{~Hz}$, $1 \mathrm{H}), 8.03(\mathrm{~d}, \mathrm{~J}=7.5 \mathrm{~Hz}, 1 \mathrm{H}), 12.45(\mathrm{~s}, 1 \mathrm{H}) .{ }^{13} \mathrm{C}$ NMR $\left(75 \mathrm{MHz}, 30{ }^{\circ} \mathrm{C}, \mathrm{DMSO}-\mathrm{d}_{6}\right) \delta$ $14.62,18.00,22.77,25.86,29.35,29.38,29.50,29.61,29.68,29.71,31.98,35.86$, 42.30, 48.08, 169.41, 172.15, 174.64. IR cm ${ }^{-1} ; 3289,3102,2850,2570,1726,1641$, 1570, 1208. HRMS (ESI-TOF, positive mode) $\mathrm{m} / \mathrm{z}$ exp $[\mathrm{M}+\mathrm{Na}]^{+}$calcd for $\mathrm{C}_{17} \mathrm{H}_{32} \mathrm{~N}_{2} \mathrm{O}_{4} \mathrm{Na}^{+}$; 351.2254; found, $351.2254[\mathrm{M}+\mathrm{Na}]^{+}, 679.4482[2 \mathrm{M}+\mathrm{Na}]^{+},(\Delta=$ $0.0 \mathrm{ppm})$.

Benzoyl-glycyl-L-alanine (3d). White solid (Yield: $91 \%$ ). $\mathrm{mp}: 187-189^{\circ} \mathrm{C} . \mathrm{Rf}=0.51$ (MeOH: $\left.\mathrm{CH}_{2} \mathrm{Cl}_{2}, 10: 90\right) .{ }^{1} \mathrm{H}$ NMR $\left(300 \mathrm{MHz}, 30^{\circ} \mathrm{C}\right.$, DMSO- $\left.\mathrm{d}_{6}\right) \delta 1.26(\mathrm{~d}, \mathrm{~J}=7.2 \mathrm{~Hz}$, $3 \mathrm{H}), 3.87(\mathrm{~m}, 2 \mathrm{H}), 4.20(\mathrm{~m}, 1 \mathrm{H}), 7.43-7.53(\mathrm{~m}, 3 \mathrm{H}), 7.85(\mathrm{dd}, \mathrm{J}=6.6, \mathrm{~J}=1.8 \mathrm{~Hz}, 2 \mathrm{H})$, $8.19(\mathrm{~d}, \mathrm{~J}=5.1 \mathrm{~Hz}, 1 \mathrm{H}), 8.65(\mathrm{t}, \mathrm{J}=7.5 \mathrm{~Hz}, 1 \mathrm{H}), 12.14(\mathrm{~s}$, broad, $1 \mathrm{H}) .{ }^{13} \mathrm{C}$ NMR $(75$ MHz, $30{ }^{\circ} \mathrm{C}$, DMSO- $\left.\mathrm{d}_{6}\right) \delta 18.02,42.94,48.20,128.00,128.96,132.00,134.74$, 167.13, 169.38, 174.68. IR cm${ }^{-1} ; 3518,3382,3075,2929,1715,1626,1492,1293$. HRMS (ESI-TOF, positive mode) $\mathrm{m} / \mathrm{z}$ exp $[\mathrm{M}+\mathrm{Na}]^{+}$calcd for $\mathrm{C}_{12} \mathrm{H}_{14} \mathrm{~N}_{2} \mathrm{O}_{4} \mathrm{Na}^{+}$; 273.0846; found, $273.08567[\mathrm{M}+\mathrm{Na}]^{+}, 523.1891[2 \mathrm{M}+\mathrm{Na}]^{+},(\Delta=3.9 \mathrm{ppm})$.

(4-nitro-benzoyl)-glycyl-L-alanine (3e). White solid (Yield: $89 \%$ ). mp: $194-198{ }^{\circ} \mathrm{C}$. $\mathrm{Rf}=0.54\left(\mathrm{MeOH}: \mathrm{CH}_{2} \mathrm{Cl}_{2}, 10: 90\right) .{ }^{1} \mathrm{H}$ NMR $\left(300 \mathrm{MHz}, 30^{\circ} \mathrm{C}, \mathrm{DMSO}-\mathrm{d}_{6}\right) \delta 1.25(\mathrm{~d}$, $\mathrm{J}=8.7 \mathrm{~Hz}, 3 \mathrm{H}), 3.92(\mathrm{~m}, \mathrm{~J}=6 \mathrm{~Hz}, 2 \mathrm{H}), 4.20(\mathrm{~m}, 1 \mathrm{H}), 8.07(\mathrm{~d}, \mathrm{~J}=8.7 \mathrm{~Hz}, 2 \mathrm{H}), 8.25$ (m, 3H), $9.03(\mathrm{t}, \mathrm{J}=6 \mathrm{~Hz}, 1 \mathrm{H}), 12.47$ (s br., $1 \mathrm{H}) .{ }^{13} \mathrm{C} \mathrm{NMR}\left(75 \mathrm{MHz}, 30{ }^{\circ} \mathrm{C}\right.$, DMSO$\left.\mathrm{d}_{6}\right) \delta 22.73,47.75,52.95,128.94,134.28,145.16,154.53,170.27,173.68,179.38$. IR $\mathrm{cm}^{-1} ; 3518,3290,3075,2929,1724,1687,1656,1531,1348$. HRMS (ESI-TOF, positive mode) $\mathrm{m} / \mathrm{z}$ exp $[\mathrm{M}+\mathrm{Na}]^{+}$calcd for $\mathrm{C}_{12} \mathrm{H}_{13} \mathrm{~N}_{3} \mathrm{O}_{6} \mathrm{Na}^{+}, 318,0697$; found, $318.0710[\mathrm{M}+\mathrm{Na}]^{+},(\Delta=4.0 \mathrm{ppm})$.

General Procedure for compounds 4-12. Method 1: Compound 3 (0.567 mmoles) and HOBT $(0.684 \mathrm{mmols})$ were placed in a round bottom flask with a stirrer and were dissolved in $10 \mathrm{~mL}$ of freshly dried DMF. The flask was immersed in an ice bath. To the mixture, DCC $(0.73$ mmole $)$ dissolved in $5 \mathrm{~mL}$ was added dropwise. The mixture was stirred for $2 \mathrm{~h}$ and then, amine $2(0.567 \mathrm{mmole})$ dissolved in dry DME was added dropwise. The mixture was further stirred over night at room temperature. Afterwards, reaction was quenched by adding excess of diethyl ether and then washed with water. The white product was purified through $4-5 \mathrm{~cm}$ packed column with silica by $\left(\mathrm{CH}_{2} \mathrm{Cl}_{2}: \mathrm{MeOH}, 90: 10\right)$ firstly and then with pure methanol or ethanol. Method 2: Compound 3 (0.567 mmoles), HOBT $(0.684$ mmoles $)$, EDC $(0.627$ mmoles $)$ and amine $2(0.567$ mmoles) were stirred over night in $10 \mathrm{~mL}$ of freshly dried DMF. Then, DMF is evaporated under vaccum and solid material was grind, washed in excess of water and dried under high vacuum.

N-dodecyl-[N'-dodecanoyl-glycyl- $L$-alanyl-glycyl]- $L$-alanine amide (4). Described previously. ${ }^{[9]}$

N-hexyl-[N'-hexanoyl-glycyl- $L$-alanyl-glycyl]- $L$-alanine amide (5). Method 1 White solid (Yield: 89\%). mp: 244-248 ${ }^{\circ} \mathrm{C}$. ${ }^{1} \mathrm{H}$ NMR $\left(300 \mathrm{MHz}, 30{ }^{\circ} \mathrm{C}\right.$, DMSO- $\left.\left[\mathrm{d}_{6}\right]\right)$ $\delta 0.81(\mathrm{t}, \mathrm{J}=6.0 \mathrm{~Hz}, 3 \mathrm{H}), 1.15-1.36(\mathrm{~m}, 21 \mathrm{H}), 1.46(\mathrm{~m}, 2 \mathrm{H}), 2.06(\mathrm{t}, \mathrm{J}=7.2 \mathrm{~Hz}, 2 \mathrm{H})$, $2.99(\mathrm{~m}, 2 \mathrm{H}), 3.64(\mathrm{~m}, 4 \mathrm{H}), 4.17(\mathrm{~m}, 2 \mathrm{H}), 7.73(\mathrm{~m}, 1 \mathrm{H}), 7.79(\mathrm{~m}, 1 \mathrm{H}), 8.00(\mathrm{~m}, 1 \mathrm{H})$ $8.09(\mathrm{~m}, 1 \mathrm{H}), 8.19(\mathrm{~m}, 1 \mathrm{H}) .{ }^{13} \mathrm{C}$ NMR $\left(75 \mathrm{MHz}, 30{ }^{\circ} \mathrm{C}, \mathrm{DMSO}-\mathrm{d}_{6}\right) \delta 14.42,14.48$, $14.53,18.37,18.88,22.51,22.22,25.48,26.56,29.54,31.51,31.57,35.78,42.65$, $42.84,48.94,49.31,169.03,169.94,172.55,173.49,173.64$. IR cm ${ }^{-1} ; 3292,2929$, $2859,1696,1626,1545,1448,1233$. HRMS (ESI-TOF, positive mode) $\mathrm{m} / \mathrm{z}$ exp [M + $\mathrm{Na}]^{+}$calcd for $\mathrm{C}_{22} \mathrm{H}_{41} \mathrm{~N}_{5} \mathrm{NaO}_{5}{ }^{+} 478.30$; found, $478.2986[\mathrm{M}+\mathrm{Na}]^{+},(\Delta=2.9 \mathrm{ppm})$.

N-propyl-[N'-propanoyl-glycyl- $L$-alanyl-glycyl]- $L$-alanine amide (6). Method 2 White solid (Yield: $72 \%$ ). mp: $274-275{ }^{\circ} \mathrm{C}$. ${ }^{1} \mathrm{H}$ NMR $\left(300 \mathrm{MHz}, 30{ }^{\circ} \mathrm{C}\right.$, DMSO- $\left.\mathrm{d}_{6}\right) \delta$ $0.79(\mathrm{t}, \mathrm{J}=4.5 \mathrm{~Hz}, 3 \mathrm{H}), 0.95(\mathrm{t}, \mathrm{J}=4.5 \mathrm{~Hz}, 3 \mathrm{H}), 1.15-1.21(\mathrm{~m}, 6 \mathrm{H}), 1.34-1.42(\mathrm{~m}, 2 \mathrm{H})$ $2.09(\mathrm{q}, \mathrm{J}=4.5 \mathrm{~Hz}, 2 \mathrm{H}), 2.96-3.02(\mathrm{~m}, 2 \mathrm{H}), 3.62(\mathrm{~m}, 4 \mathrm{H}), 4.22(\mathrm{~m}, 2 \mathrm{H}), 7.71(\mathrm{t}, \mathrm{J}=$ $3.3 \mathrm{~Hz}, 1 \mathrm{H}), 7.79(\mathrm{~d}, \mathrm{~J}=4.5 \mathrm{~Hz}, 1 \mathrm{H}), 7.94(\mathrm{t}, \mathrm{J}=3.3 \mathrm{~Hz}, 1 \mathrm{H}), 8.09(\mathrm{~d}, \mathrm{~J}=4.5 \mathrm{~Hz}, 1 \mathrm{H})$, $8.15(\mathrm{t}, \mathrm{J}=3.3 \mathrm{~Hz}, 1 \mathrm{H}) .{ }^{13} \mathrm{C}$ NMR $\left(75 \mathrm{MHz}, 30^{\circ} \mathrm{C}\right.$, DMSO- $\left.\mathrm{d}_{6}\right) \delta 10.64,12.18,18.77$, 19.21, 23.15, 29.16, 39.61, 42.87, 43.07, 49.13, 49.43, 169.17, 170.06, 172.72, 173.61, 174.29. IR cm ${ }^{-1}$; 3291, 3088, 2970,2876, 1694, 1626, 1543, 1444, 1235. HRMS (ESITOF, positive mode) $\mathrm{m} / \mathrm{z}$ exp $[\mathrm{M}+\mathrm{Na}]^{+}$calcd for $\mathrm{C}_{16} \mathrm{H}_{29} \mathrm{~N}_{5} \mathrm{NaO}_{5}{ }^{+}$394.2061; found, $394.2068[\mathrm{M}+\mathrm{Na}]^{+},(\Delta=1.7 \mathrm{ppm})$.

N-hexyl-[N'-dodecanoyl-glycyl- $L$-alanyl-glycyl]- $L$-alanine amide (7). Method 1 White solid (Yield: $89 \%)$. mp: $258-263{ }^{\circ} \mathrm{C} .{ }^{1} \mathrm{H}$ NMR $\left(300 \mathrm{MHz}, 30{ }^{\circ} \mathrm{C}, \mathrm{DMSO}-\mathrm{d}_{6}\right) \delta$ $0.81(\mathrm{t}, \mathrm{J}=6.9 \mathrm{~Hz}, 3 \mathrm{H}), 1.19(\mathrm{~s}, 31 \mathrm{H}), 1.33(\mathrm{t}, \mathrm{J}=6.6 \mathrm{~Hz}, 2 \mathrm{H}), 1.43(\mathrm{t}, \mathrm{J}=6.6 \mathrm{~Hz}, 2 \mathrm{H})$, $2.06(\mathrm{t}, \mathrm{J}=6.9 \mathrm{~Hz}, 2 \mathrm{H}), 3.00(\mathrm{~s}, 2 \mathrm{H}), 3.64(\mathrm{~m}, 4 \mathrm{H}), 4.15(\mathrm{~m}, 2 \mathrm{H}), 7.70(\mathrm{~m}, 2 \mathrm{H}), 7.95(\mathrm{~s}$, $1 \mathrm{H}), 8.06(\mathrm{~m}, 2 \mathrm{H}) .{ }^{13} \mathrm{C}$ NMR $\left(75 \mathrm{MHz}, 30^{\circ} \mathrm{C}\right.$, DMSO- $\left.\mathrm{d}_{6}\right) \delta 14.54,14.60,18.36$, $18.39,18.47,18.97,22.68,22.74,25.81,26.60,29.35,29.47,29.58,29.65,29.68$, $31.60,31.94,35.82,39.19,42.65,42.85,48.90,49.23,168.90,169.84,172.42,173.35$, 173.40. IR cm ${ }^{-1} ; 3296,2925,2854,1696,1627,1560,1449,1238$. HRMS (ESI-TOF, positive mode) $\mathrm{m} / \mathrm{z}$ exp $[\mathrm{M}+\mathrm{Na}]^{+}$calcd for $\mathrm{C}_{28} \mathrm{H}_{53} \mathrm{~N}_{5} \mathrm{NaO}_{5}^{+} 562.3939$; found, $562.3918[\mathrm{M}+\mathrm{Na}]^{+},(\Delta=3.7 \mathrm{ppm})$.

N-propyl-[N'-docecanoyl-glycyl- $L$-alanyl-glycyl]- $L$-alanine amide (8). Method 1 White solid (Yield: $92 \%$ ). mp: 259-262 ${ }^{\circ} \mathrm{C} .{ }^{1} \mathrm{H}$ NMR $\left(300 \mathrm{MHz}, 30{ }^{\circ} \mathrm{C}\right.$, DMSO- $\left.\mathrm{d}_{6}\right) \delta$ $0.80(\mathrm{~m}, 6 \mathrm{H}), 1.191-1.24(\mathrm{~m}, 20 \mathrm{H}), 1.37-1.49(\mathrm{~m}, 6 \mathrm{H}), 2.09(\mathrm{t}, \mathrm{J}=7.5 \mathrm{~Hz}, 2 \mathrm{H}), 2.97(\mathrm{~s}$, 
2H) $3.68(\mathrm{~m}, \mathrm{~J}=4.5 \mathrm{~Hz}, 4 \mathrm{H}), 4.20(\mathrm{~m}, 2 \mathrm{H}), 7.50(\mathrm{~s}, 1 \mathrm{H}), 7.58(\mathrm{~s}, 1 \mathrm{H}), 7.73(\mathrm{~s}, 1 \mathrm{H})$ $7.83(\mathrm{~s}, 1 \mathrm{H}), 7.95(\mathrm{~s}, 1 \mathrm{H}) .{ }^{13} \mathrm{C}$ NMR $\left(75 \mathrm{MHz}, 30{ }^{\circ} \mathrm{C}\right.$, DMSO- $\left.\mathrm{d}_{6}\right) \delta 11.97,14.63$, $18.56,19.01,22.77,22.92,25.84,29.36,29.38,29.49,29.60,29.68,29.70,31.97$, $35.82,39.38,42.62,42.83,48.90,49.19,168.93,169.81,172.50,173.32,173.34$ HRMS (ESI-TOF, positive mode) $\mathrm{m} / \mathrm{z}$ exp $[\mathrm{M}+\mathrm{Na}]^{+}$calcd for $\mathrm{C}_{25} \mathrm{H}_{47} \mathrm{~N}_{5} \mathrm{NaO}_{5}{ }^{+}$ 520.3469 ; found, $520.3478[\mathrm{M}+\mathrm{Na}]^{+},(\Delta=1.7 \mathrm{ppm})$.

N-dodecyl-[N'-hexanoyl-glycyl-L-alanyl-glycyl]- $L$-alanine amide (9). Method 1. White solid (Yield: 86\%). mp: $264-267{ }^{\circ} \mathrm{C} .{ }^{1} \mathrm{H}$ NMR $\left(300 \mathrm{MHz}, 30{ }^{\circ} \mathrm{C}\right.$, DMSO- $\left.\mathrm{d}_{6}\right) \delta$ $0.82(\mathrm{t}, \mathrm{J}=6.3 \mathrm{~Hz}, 3 \mathrm{H}), 1.15-1.21(\mathrm{~m}, 33 \mathrm{H}), 1.45(\mathrm{~m}, 2 \mathrm{H}), 2.09(\mathrm{t}, \mathrm{J}=7.2 \mathrm{~Hz}, 2 \mathrm{H})$ $3.01(\mathrm{~m}, 2 \mathrm{H}), 3.66(\mathrm{~m}, 4 \mathrm{H}), 4.17(\mathrm{~m}, 2 \mathrm{H}), 7.60(\mathrm{~s}, 1 \mathrm{H}), 7.69(\mathrm{~d}, \mathrm{~J}=6.6 \mathrm{~Hz}, 1 \mathrm{H}), 7.88$ $(\mathrm{s}, 1 \mathrm{H}), 8.01(\mathrm{~s}, 1 \mathrm{H}), 8.14(\mathrm{~s}, 1 \mathrm{H}) \cdot{ }^{13} \mathrm{C}$ NMR $\left(75 \mathrm{MHz}, 30{ }^{\circ} \mathrm{C}\right.$, DMSO- $\left.\mathrm{d}_{6}\right) \delta 14.39$ $14.49,18.46,18.94,22.47,22.67,25.11,25.45,26.97,29.29,29.36,3 \mathrm{C}(29.61), 31.57$ $31.91,35.88,39.21,39.63,42.92,43.08,49.03,49.36,168.95,169.88,172.47,173.35$, 173.38. IR cm ${ }^{-1} ; 3293,2925,2854,1696,1622,1560,1448,1235$. HRMS (ESI-TOF, positive mode) $\mathrm{m} / \mathrm{z}$ exp $[\mathrm{M}+\mathrm{Na}]^{+}$calcd for $\mathrm{C}_{28} \mathrm{H}_{53} \mathrm{~N}_{5} \mathrm{NaO}_{5}{ }^{+}$562.3939; found, $562.3923[\mathrm{M}+\mathrm{Na}]^{+},(\Delta=2.8 \mathrm{ppm})$.

N-propyl-[N'-hexanoyl-glycyl- $L$-alanyl-glycyl]- $L$-alanine amide (10). Method 1. White solid (Yield: $87 \%$ ). mp: $244-245{ }^{\circ} \mathrm{C}$. ${ }^{1} \mathrm{H}$ NMR $\left(300 \mathrm{MHz}, 30{ }^{\circ} \mathrm{C}\right.$, DMSO- $\left.\mathrm{d}_{6}\right) \delta$ $0.78(\mathrm{~m}, 6 \mathrm{H}), 1.16-1.23(\mathrm{~m}, 10 \mathrm{H}), 1.34-1.51(\mathrm{~m}, 4 \mathrm{H}), 2.06(\mathrm{t}, \mathrm{J}=7.5 \mathrm{~Hz}, 2 \mathrm{H}), 2.94(\mathrm{q}$, $\mathrm{J}=6.9 \mathrm{~Hz}, 2 \mathrm{H}), 3.64(\mathrm{~m}, 4 \mathrm{H}), 4.16(\mathrm{~m}, 2 \mathrm{H}), 7.72(\mathrm{t}, \mathrm{J}=5.4 \mathrm{~Hz}, 1 \mathrm{H}), 7.81(\mathrm{~d}, \mathrm{~J}=7.5$ $\mathrm{Hz}, 1 \mathrm{H}), 7.97(\mathrm{t}, \mathrm{J}=5.4 \mathrm{~Hz}, 1 \mathrm{H}), 8.09(\mathrm{~d}, \mathrm{~J}=6.6 \mathrm{~Hz}, 1 \mathrm{H}), 8.18(\mathrm{t}, \mathrm{J}=5.4 \mathrm{~Hz}, 1 \mathrm{H})$. ${ }^{13} \mathrm{C}$ NMR $\left(75 \mathrm{MHz}, 30{ }^{\circ} \mathrm{C}\right.$, DMSO- $\left.\mathrm{d}_{6}\right) \delta 11.96,14.25,18.58,19.01,22.56,22.92$, 25.52, 31.55, 35.78, 42.63, 42.83, 48.90, 49.18, 49.27, 168.94, 169.81, 172.50, 173.34 173.37. IR cm ${ }^{-1} ; 3293,2961,2854,1696,1622,1542,1444,1248$. HRMS (ESI-TOF, positive mode) $\mathrm{m} / \mathrm{z}$ exp $[\mathrm{M}+\mathrm{Na}]^{+}$calcd for $\mathrm{C}_{19} \mathrm{H}_{35} \mathrm{~N}_{5} \mathrm{NaO}_{5}{ }^{+} 436.253$; found, $436.2520[\mathrm{M}+\mathrm{Na}]^{+}, 413.2654[\mathrm{M}+\mathrm{H}]^{+},(\Delta=2.2 \mathrm{ppm})$.

N-dodecyl-[N'-propanoyl-glycyl- $L$-alanyl-glycyl]- $L$-alanine amide (11). Method 2. White solid (Yield: $98 \%)$ mp: $234-238{ }^{\circ} \mathrm{C}$. ${ }^{1} \mathrm{H}$ NMR $\left(300 \mathrm{MHz}, 30{ }^{\circ} \mathrm{C}\right.$, DMSO- $\left.\mathrm{d}_{6}\right) \delta$ $0.81(\mathrm{t}, \mathrm{J}=6.9 \mathrm{~Hz}, 3 \mathrm{H}), 0.85(\mathrm{t}, \mathrm{J}=7.5 \mathrm{~Hz}, 3 \mathrm{H}), 1.15-1.22(\mathrm{~m}, 11 \mathrm{H}), 1.35(\mathrm{~s}, 2 \mathrm{H})$, $2.07(\mathrm{q}, \mathrm{J}=7.5 \mathrm{~Hz}, 2 \mathrm{H}), 2.99(\mathrm{~s}, 2 \mathrm{H}), 3.68(\mathrm{~m}, 4 \mathrm{H}), 4.17(\mathrm{~m}, 2 \mathrm{H}), 7.74(\mathrm{~s}, 1 \mathrm{H}), 7.82(\mathrm{~d}$, $\mathrm{J}=6 \mathrm{~Hz}, 1 \mathrm{H}), 7.99(\mathrm{t}, \mathrm{J}=1 \mathrm{H}), 8.15(\mathrm{~m}, 2 \mathrm{H}) .{ }^{13} \mathrm{C} \mathrm{NMR}\left(75 \mathrm{MHz}, 30{ }^{\circ} \mathrm{C}\right.$, DMSO- $\left.\mathrm{d}_{6}\right) \delta$ $10.45,14.59,18.57,19.04,19.19,33.73,26.64,28.94,29.65,31.64,32.96,39.21$, 42.67, 42.86, 48.81, 48.91, 49.22, 168.94, 169.86, 172.44, 173.39, 174.08. IR cm ${ }^{-1}$; 3290, 3084, 2925, 2854, 1694, 1626, 1545, 1444, 1234. HRMS (ESI-TOF, positive mode) $\mathrm{m} / \mathrm{z} \exp [\mathrm{M}+\mathrm{Na}]^{+}$calcd for $\mathrm{C}_{22} \mathrm{H}_{34} \mathrm{~N}_{6} \mathrm{NaO}_{5}{ }^{+} 520.3469$; found, $520.3458[\mathrm{M}+$ $\mathrm{Na}]^{+},(\Delta=1.9 \mathrm{ppm})$

N-hexyl-[N'-propanoyl-glycyl- $L$-alanyl-glycyl]- $L$-alanine amide (12). Method 2. White solid (Yield: $78 \%$ ). mp: $269-271{ }^{\circ} \mathrm{C}$. ${ }^{1} \mathrm{H}$ NMR $\left(300 \mathrm{MHz}, 30{ }^{\circ} \mathrm{C}\right.$, DMSO- $\left.\mathrm{d}_{6}\right) \delta$ $0.81(\mathrm{t}, \mathrm{J}=6.3 \mathrm{~Hz}, 3 \mathrm{H}), 0.95(\mathrm{t}, \mathrm{J}=6.3 \mathrm{~Hz}, 3 \mathrm{H}), 1.15-1.21(\mathrm{~m}, 12 \mathrm{H}), 1.35(\mathrm{q}, \mathrm{J}=7.8$ $\mathrm{Hz}, 2 \mathrm{H}), 2.06(\mathrm{q}, \mathrm{J}=7.8 \mathrm{~Hz}, 2 \mathrm{H}), 2.98(\mathrm{~d}, \mathrm{~J}=7.8 \mathrm{~Hz}, 2 \mathrm{H}), 3.66(\mathrm{~m}, 4 \mathrm{H}), 4.17(\mathrm{~m}, 2 \mathrm{H})$, $7.72(\mathrm{t}, \mathrm{J}=3.3 \mathrm{~Hz}, 1 \mathrm{H}), 7.79(\mathrm{~d}, \mathrm{~J}=4.0 \mathrm{~Hz}, 1 \mathrm{H}), 7.96(\mathrm{t}, \mathrm{J}=3.3 \mathrm{~Hz}, 1 \mathrm{H}), 8.10(\mathrm{~d}, \mathrm{~J}=$ $4.0 \mathrm{~Hz}, 1 \mathrm{H}), 8.16(\mathrm{t}, \mathrm{J}=3.6 \mathrm{~Hz}, 1 \mathrm{H}) .{ }^{13} \mathrm{C}$ NMR $\left(75 \mathrm{MHz}, 30{ }^{\circ} \mathrm{C}, \mathrm{DMSO}-\mathrm{d}_{6}\right) \delta 10.45$, $14.59,18.57,19.04,22.73,26.64,28.95,29.65,31.64,39.21,42.67,42.86,48.90$ $49.22,168.95,169.87,172.45,173.41,174.08 . \mathrm{IR} \mathrm{cm}^{-1} ; 3291,3089,2930,2859,1694$ $1626,1545,1443,1235$. HRMS (ESI-TOF, positive mode) $\mathrm{m} / \mathrm{z}$ exp $[\mathrm{M}+\mathrm{Na}]^{+}$calcd for $\mathrm{C}_{19} \mathrm{H}_{35} \mathrm{~N}_{5} \mathrm{NaO}_{5}{ }^{+}$436.2530; found, $436.2554[\mathrm{M}+\mathrm{Na}]_{+}, 849.5322[2 \mathrm{M}+\mathrm{Na}]^{+},(\Delta$ $=5.5 \mathrm{ppm})$.

N-propyl-[N'-benzoyl-glycyl- $L$-alanyl-glycyl]- $L$-alanine amide (13). Method 1 . White powder (Yield: 85\%). m.p. $233.5^{\circ} \mathrm{C}$. $\mathrm{Rf}=0.46\left(\mathrm{MeOH}: \mathrm{CH}_{2} \mathrm{Cl}_{2}, 10: 90\right) .{ }^{1} \mathrm{H}$ NMR $\left(300 \mathrm{MHz}, 30{ }^{\circ} \mathrm{C}\right.$, DMSO- $\left.\mathrm{d}_{6}\right) \delta 0.76(\mathrm{t}, \mathrm{J}=7.2 \mathrm{~Hz}, 3 \mathrm{H}), 1.11(\mathrm{~d}, \mathrm{~J}=7.2 \mathrm{~Hz}$, $3 \mathrm{H}), 1.17(\mathrm{~d}, \mathrm{~J}=7.2 \mathrm{~Hz}, 3 \mathrm{H}), 1.35-1.42(\mathrm{~m}, 2 \mathrm{H}), 2.93(\mathrm{t}, \mathrm{J}=6.6 \mathrm{~Hz}, 2 \mathrm{H}), 3.67(\mathrm{~m}, 2 \mathrm{H})$ $3.90(\mathrm{~m}, 3 \mathrm{H}), 4.14-4.27(\mathrm{~m}, 2 \mathrm{H}), 7.42(\mathrm{~m}, 2 \mathrm{H}), 7.69(\mathrm{t}, \mathrm{J}=5.1 \mathrm{~Hz}, 1 \mathrm{H}), 7.78(\mathrm{~m}, 3 \mathrm{H})$, $8.21(\mathrm{t}, \mathrm{J}=6.6 \mathrm{~Hz}, 2 \mathrm{H}), 8.69(\mathrm{t}, \mathrm{J}=5.1 \mathrm{~Hz}, 1 \mathrm{H}) .{ }^{13} \mathrm{C}$ NMR $\left(75 \mathrm{MHz}, 30{ }^{\circ} \mathrm{C}\right.$, DMSO$\left.\mathrm{d}_{6}\right) \delta 11.95,18.55,18.94,22.91,39.40,42.87,43.26,48.91,49.32,127.97,128.95$, $132.02,134.63,167.25,168.95,169.78,172.48,173.40$. IR cm ${ }^{-1} ; 3283,2969,2854$, $1696,1622,1542,1446,1234$. HRMS (ESI-TOF, positive mode) $\mathrm{m} / \mathrm{z} \exp [\mathrm{M}+\mathrm{Na}]^{+}$ calcd for $\mathrm{C}_{20} \mathrm{H}_{29} \mathrm{~N}_{5} \mathrm{NaO}_{5}^{+} 442.2061$; found, $442.2061[\mathrm{M}+\mathrm{Na}]^{+},(\Delta=0.0 \mathrm{ppm})$.

N-propyl-[N'-(4-nitro-benzoyl)-glycyl- $L$-alanyl-glycyl]-L-alanine amide (14). Method 2. White powder (Yield: 77\%).m.p. $249-253{ }^{\circ} \mathrm{C}$. $\mathrm{Rf}=0.43\left(\mathrm{MeOH}: \mathrm{CH}_{2} \mathrm{Cl}_{2}\right.$, 10:90). ${ }^{1} \mathrm{H}$ NMR $\left(300 \mathrm{MHz}, 30^{\circ} \mathrm{C}\right.$, DMSO- $\left.\mathrm{d}_{6}\right) \delta 0.75(\mathrm{t}, \mathrm{J}=7.2 \mathrm{~Hz}, 3 \mathrm{H}), 1.11(\mathrm{~d}, \mathrm{~J}=$ $6.9 \mathrm{~Hz}, 3 \mathrm{H}), 1.22(\mathrm{~d}, \mathrm{~J}=6.9 \mathrm{~Hz}, 3 \mathrm{H}), 1.32(\mathrm{~m}, 2 \mathrm{H}), 2.93(\mathrm{~d}, \mathrm{~J}=6.9 \mathrm{~Hz}, 2 \mathrm{H}), 3.63(\mathrm{~m}$, 2H), $3.88(\mathrm{~m}, 2 \mathrm{H}), 4.13(\mathrm{~m}, 1 \mathrm{H}), 4.22(\mathrm{~m}, 1 \mathrm{H}), 7.69(\mathrm{t}, \mathrm{J}=5.4 \mathrm{~Hz}, 1 \mathrm{H}), 7.72(\mathrm{~d}, \mathrm{~J}=$ $7.2 \mathrm{~Hz}, 1 \mathrm{H}), 8.05(\mathrm{~d}, \mathrm{~J}=8.7 \mathrm{~Hz}, 2 \mathrm{H}), 8.18(\mathrm{t}, \mathrm{J}=5.4 \mathrm{~Hz}, 1 \mathrm{H}), 8.28(\mathrm{t}, \mathrm{J}=8.1 \mathrm{~Hz}, 3 \mathrm{H})$, $9.02(\mathrm{t}, \mathrm{J}=5.4 \mathrm{~Hz}, 1 \mathrm{H}) .{ }^{13} \mathrm{C}$ NMR $\left(75 \mathrm{MHz}, 30{ }^{\circ} \mathrm{C}\right.$, DMSO- $\left.\mathrm{d}_{6}\right) \delta 11.90,18.43,18.87$, $22.86,39.24,42.84,43.26,48.96,49.41,124.20,129.50,140.27,149.80,165.77$, 169.04, 169.42, 172.60, 173.47. IR cm ${ }^{-1} ; 3280,2922,2854,1696,16226,1545,1448$, 1349. HRMS (ESI-TOF, positive mode) $\mathrm{m} / \mathrm{z} \exp [\mathrm{M}+\mathrm{Na}]^{+}$calcd for $\mathrm{C}_{20} \mathrm{H}_{28} \mathrm{~N}_{6} \mathrm{NaO}_{7}{ }^{+}$ 487.1912 ; found, $487.1914[\mathrm{M}+\mathrm{Na}]^{+},(\Delta=0.4 \mathrm{ppm})$.

N-hexyl-[N'-benzoyl-glycyl- $\boldsymbol{L}$-alanyl-glycyl]- $\boldsymbol{L}$-alanine amide (15). Method 1. White powder (Yield: $80 \%$ ). m.p. 238. $\mathrm{Rf}=0.58\left(\mathrm{MeOH}: \mathrm{CH}_{2} \mathrm{Cl}_{2}, 10: 90\right)$. 1H NMR $\left(300 \mathrm{MHz}, 30^{\circ} \mathrm{C}\right.$, DMSO- $\left.\mathrm{d}_{6}\right) \delta 0.81(\mathrm{t}, \mathrm{J}=6.9 \mathrm{~Hz}, 3 \mathrm{H}), 1.13(\mathrm{~d}, \mathrm{~J}=7.2 \mathrm{~Hz}, 3 \mathrm{H})$,
1.14-1.35 (m, 11H), 1.34-1.42 (m, 2H), $2.98(\mathrm{~d}, \mathrm{~J}=5.7 \mathrm{~Hz}, 2 \mathrm{H}), 3.66(\mathrm{~m}, 2 \mathrm{H}), 3.89(\mathrm{~m}$, $2 \mathrm{H}), 4.16-4.25(\mathrm{~m}, 2 \mathrm{H}), 7.42(\mathrm{~m}, 3 \mathrm{H}), 7.68(\mathrm{~s}, 1 \mathrm{H}), 7.76(\mathrm{~d}, \mathrm{~J}=7.8 \mathrm{~Hz}, 1 \mathrm{H}), 7.83(\mathrm{~d}, \mathrm{~J}$ $=8.4 \mathrm{~Hz}, 1 \mathrm{H}), 8.18(\mathrm{t}, \mathrm{J}=6.9 \mathrm{~Hz}, 1 \mathrm{H}), 8.69(\mathrm{t}, \mathrm{J}=6.9 \mathrm{~Hz}, 1 \mathrm{H}) .{ }^{13} \mathrm{C} \mathrm{NMR}(75 \mathrm{MHz}$, $30{ }^{\circ} \mathrm{C}$, DMSO- $\left.\mathrm{d}_{6}\right) \delta 14.54,18.42,18.84,22.67,26.56,29.55,31.58,39.28,42.88$, 43.26, 48.93, 49.42, 127.95, 128.96, 132.06, 134.54, 167.35, 169.01, 169.89, 172.49, 173.48. IR cm ${ }^{-1} ; 3283,2929,2857,1696,1622,1542,1448,1235$. HRMS (ESI-TOF, positive mode) $\mathrm{m} / \mathrm{z}$ exp $[\mathrm{M}+\mathrm{Na}]^{+}$calcd for $\mathrm{C}_{23} \mathrm{H}_{35} \mathrm{~N}_{5} \mathrm{NaO}_{5}^{+} 484.253$; found, $484.2521[\mathrm{M}+\mathrm{Na}]^{+}, 945.3710[2 \mathrm{M}+\mathrm{Na}]^{+},(\Delta=1.8 \mathrm{ppm})$.

N-hexyl-[N'-(4-nitro-benzoyl)-glycyl- $L$-alanyl-glycyl]- $L$-alanine amide (16). Method 1. White powder (Yield: $81 \%$ ). m.p. $258.4{ }^{\circ} \mathrm{C}$. $\mathrm{Rf}=0.34\left(\mathrm{MeOH}: \mathrm{CH}_{2} \mathrm{Cl}_{2}\right.$, 10:90). 1H NMR (300 MHz, $30^{\circ} \mathrm{C}$, DMSO- $\left.\mathrm{d}_{6}\right) \delta 0.86(\mathrm{t}, \mathrm{J}=6.6 \mathrm{~Hz}, 3 \mathrm{H}), 1.11(\mathrm{~d}, \mathrm{~J}=$ $7.2 \mathrm{~Hz}, 3 \mathrm{H}), 1.22(\mathrm{~m}, 9 \mathrm{H}), 1.34(\mathrm{t}, \mathrm{J}=6.3 \mathrm{~Hz}, 2 \mathrm{H}), 2.97(\mathrm{~m}, 2 \mathrm{H}), 3.68(\mathrm{t}, \mathrm{J}=6.3 \mathrm{~Hz}$, $2 \mathrm{H}), 3.94(\mathrm{~d}, \mathrm{~J}=6.3 \mathrm{~Hz}, 2 \mathrm{H}), 4.14-4.28(\mathrm{~m}, 2 \mathrm{H}), 7.69(\mathrm{t}, \mathrm{J}=6.6 \mathrm{~Hz}, 1 \mathrm{H}), 7.78(\mathrm{~d}, \mathrm{~J}=$ $7.5 \mathrm{~Hz}, 1 \mathrm{H}), 8.07(\mathrm{~d}, \mathrm{~J}=9.0 \mathrm{~Hz}, 2 \mathrm{H}), 8.19(\mathrm{t}, \mathrm{J}=6.3 \mathrm{~Hz}, 1 \mathrm{H}), 8.27(\mathrm{~m}, 3 \mathrm{H}), 9.03(\mathrm{t}, \mathrm{J}$ $=5.1 \mathrm{~Hz}, 1 \mathrm{H}) .{ }^{13} \mathrm{C}$ NMR $\left(75 \mathrm{MHz}, 30{ }^{\circ} \mathrm{C}\right.$, DMSO- $\left.\mathrm{d}_{6}\right) \delta 14.36,18.49,18.54,22.66$, 26.56, 29.55, 31.57, 39.67, 43.21, 43.23, 48.82, 49.28, 124.04, 129.37, 140.26, 149.76, 165.62, 168.90, 169.29, 172.41, 173.33. IR cm ${ }^{-1} ; 3300,2930,2854,1696,1629,1528$, 1443, 1238. HRMS (ESI-TOF, positive mode) $\mathrm{m} / \mathrm{z}$ exp $[\mathrm{M}+\mathrm{Na}]^{+}$calcd for $\mathrm{C}_{23} \mathrm{H}_{34} \mathrm{~N}_{6} \mathrm{NaO}_{7}^{+} 529.2381$; found, $529.2352[\mathrm{M}+\mathrm{Na}]^{+},(\Delta=5.4 \mathrm{ppm})$.

N-dodecyl-[N'-benzoyl-glycyl- $L$-alanyl-glycyl]- $L$-alanine amide (17). Method 1. White powder (Yield: $80 \%$ ). m.p. $277.2{ }^{\circ} \mathrm{C}$. $\mathrm{Rf}=0.58\left(\mathrm{MeOH}: \mathrm{CH}_{2} \mathrm{Cl}_{2}, 10: 90\right) .{ }^{1} \mathrm{H}$ NMR ( $300 \mathrm{MHz}, 30^{\circ} \mathrm{C}$, DMSO- $\left.\mathrm{d}_{6}\right) \delta 080(\mathrm{t}, \mathrm{J}=6.6 \mathrm{~Hz}, 3 \mathrm{H}), 1.10(\mathrm{~d}, \mathrm{~J}=7.2 \mathrm{~Hz}, 3 \mathrm{H})$, $1.20-1.33(\mathrm{~m}, 23 \mathrm{H}), 2.97(\mathrm{~m}, 2 \mathrm{H}), 3.65(\mathrm{~m}, 2 \mathrm{H}), 3.88(\mathrm{~m}, 2 \mathrm{H}), 4.10-4.25(\mathrm{~m}, 2 \mathrm{H})$, 7.44-7.51 (m, 3H), $7.68(\mathrm{t}, \mathrm{J}=5 \mathrm{~Hz}, 1 \mathrm{H}), 7.77(\mathrm{~d}, \mathrm{~J}=6 \mathrm{~Hz}, 1 \mathrm{H}), 7.83(\mathrm{dd}, \mathrm{J}=6.9,1.5$ $\mathrm{Hz}, 2 \mathrm{H}), 8.19(\mathrm{~m}, 2 \mathrm{H}), 8.70(\mathrm{t}, \mathrm{J}=5 \mathrm{~Hz}, 1 \mathrm{H}) .{ }^{13} \mathrm{C}$ NMR $\left(75 \mathrm{MHz}, 30{ }^{\circ} \mathrm{C}\right.$, DMSO- $\left.\mathrm{d}_{6}\right)$ $\delta 14.60,18.45,18.88,22.74,26.92,3 \mathrm{C}(29.35), 5 \mathrm{C}(29.64), 29.69,31.95,39.19,42.87$, 43.26, 48.91, 49.37, 127.95, 128.96, 132.05, 134.57, 167.33, 168.97, 169.84, 172.45, 173.44. IR cm ${ }^{-1} ; 3282,2924,2853,1696,1622,1542,1448,1236$. HRMS (ESI-TOF, positive mode) $\mathrm{m} / \mathrm{z}$ exp $[\mathrm{M}+\mathrm{Na}]^{+}$calcd for $\mathrm{C}_{29} \mathrm{H}_{47} \mathrm{~N}_{5} \mathrm{NaO}_{5}{ }^{+} 568.3469$; found, $568.3451[\mathrm{M}+\mathrm{Na}]^{+},(\Delta=3.1 \mathrm{ppm})$.

N-dodecyl-[N'-(4-nitro-benzoyl)-glycyl- $L$-alanyl-glycyl]- $L$-alanine amide (18). Method 1. White powder (Yield: $89 \%$ ). m.p. $247.1^{\circ} \mathrm{C} . \mathrm{Rf}=0.57\left(\mathrm{MeOH}: \mathrm{CH}_{2} \mathrm{Cl}_{2}\right.$, 10:90). ${ }^{1} \mathrm{H}$ NMR $\left(300 \mathrm{MHz}, 30{ }^{\circ} \mathrm{C}\right.$, DMSO- $\left.\mathrm{d}_{6}\right) \delta 0.83(\mathrm{t}, \mathrm{J}=6.3 \mathrm{~Hz}, 3 \mathrm{H}), 1.11-1.24$ $(\mathrm{m}, 26 \mathrm{H}), 2.98(\mathrm{~m}, 2 \mathrm{H}), 3.66(\mathrm{~m}, 2 \mathrm{H}), 3.93(\mathrm{~m}, 2 \mathrm{H}), 4.11-4.23(\mathrm{~m}, 2 \mathrm{H}), 7.71(\mathrm{t}, \mathrm{J}=5$ $\mathrm{Hz}, 1 \mathrm{H}), 7.81(\mathrm{~d}, \mathrm{~J}=6 \mathrm{~Hz}, 1 \mathrm{H}), 8.08(\mathrm{~m}, 3 \mathrm{H}), 8.08(\mathrm{~m}, 3 \mathrm{H}), 9.03(\mathrm{t}, \mathrm{J}=5.1 \mathrm{~Hz}, 1 \mathrm{H})$. ${ }^{13} \mathrm{C}$ NMR $\left(75 \mathrm{MHz}, 30{ }^{\circ} \mathrm{C}\right.$, DMSO- $\left.\mathrm{d}_{6}\right) \delta 14.52,16.77,18.40,18.85,22.65,26.82,3 \mathrm{C}$ (29.26), 5C (29.55), 31.85, 39.14, 42.67, 43.11, 48.75, 49.20, 124.09, 129.39, 140.15, 149.64, 165.50, 168.82, 169.21, 172.31, 173.24. IR cm ${ }^{-1} ; 3299,2921,2851,1696$, $1639,1560,1451,1234,1109$. HRMS (ESI-TOF, positive mode) $\mathrm{m} / \mathrm{z} \exp [\mathrm{M}+\mathrm{Na}]^{+}$ calcd for $\mathrm{C}_{29} \mathrm{H}_{46} \mathrm{~N}_{6} \mathrm{NaO}_{7}^{+} 613.3320$; found, $613.3358[\mathrm{M}+\mathrm{Na}]^{+},(\Delta=6.1 \mathrm{ppm})$.

Gelation Tests. A given amount of the studied compound was weighted in a screwcapped vial of $20 \mathrm{~mm}$ diameter, suspended in $1 \mathrm{~mL}$ of solvent and sonicated for 10 minutes. Then, the vial was heated-up until the solid was dissolved, and afterwards left to spontaneously cool to room temperature. A gel $(\mathrm{G})$ was considered being formed when no gravitational flux was observed upon vial inversion. The term weak gel (WG) was applied to the case where partial fluxion was observed.

Scanning Electron Microscopy. Scanning electron micrographs were taken in a LEO 440I microscope equipped with a digital camera. Samples of the xerogels were prepared by placing the gel on top of a tin plate and, after vacuum drying of the solvent, sputtering with $\mathrm{Au} / \mathrm{Pd}$ in a Polaron SC7610 Sputter Coater from Fisons Instruments.

Solid state CD. A sample of the gel was dried under vacuum and then $\mathrm{KBr}$ discs were prepared by mixing 1-2 $\mathrm{mg}$ of the xerogel and $200 \mathrm{mg}$ of dry $\mathrm{KBr}$ in an agate mortar and pressing the mixture at 10 ton for ca. 10 minutes. Transparent discs of less than $0.5 \mathrm{~mm}$ were obtained and their CD spectra were randomly taken in at least six different positions of the disc and averaged ${ }^{[21]}$ Spectra were recorded with a JASCO J810 spectropolarimeter.

FT-IR. $\mathrm{KBr}$ pellets of the xerogels were prepared as stated above. Spectra were collected with a JASCO-FT/IR-6200 spectrometer.

$\mathrm{X}$-ray powder diffraction. Data collection was performed at room temperature on a Bruker D4 Endeavor X-ray powder diffractometer using $\mathrm{Cu}-\mathrm{K} \alpha$ radiation. Samples of the powdered xerogels were placed on a sample holder and data were collected for $2 \theta$ values between $2^{\circ}$ and $40^{\circ}$ with a step size of $0.03^{\circ}$ and a time step of $10 \mathrm{~s}$.

Supporting Information (see footnote on the first page of this article): CD, FT-IR, powder diffraction and NMR data for all the described compounds. 


\section{Acknowledgements}

The authors thank Spanish Ministry of Science and Innovation (Grant CTQ2006-14984) and Universitat Jaume I (Grant P1 1A2006-01) for funding. S. I. thanks Universitat Jaume I -Bancaixa for a fellowship. Technical assistance by SCIC is also acknowledged.

[1] (a) H. -A Klok,. Angew. Chem. Int. Ed. 2002, 41, 1509-1513. (b) J. M. C. van Hest, D. A. Tirrell, Chem. Commun. 2001, 1897-1904. (c) J. S. Nowick, Org. Biomol. Chem. 2006, 4, 3869-3885. (d) M. A. B. Block, S. Hecht, Angew. Chem. Int. Ed. 2005, 44, 6986-6989.

[2] Self-assembling Peptide Systems in Biology, Medicine and Engineering; A. Aggeli, N. Boden, S. Zhang, Kluwer: Dordrecht, 2001 .

[3] Bioorganic Chemistry, Peptides and Proteins, S. M. Hecht, Ed.; Oxford University Press, New York, 1998.

[4] (a) C. M. Dobson, Phil. Trans. R. Soc. Lond. B 2001, 356, 133-145. (b) O. Sumner Markin, L. C. Serpell, FEBS J. 2005, 272, 5950-5961. (c) R. Krishnan, S. L. Lindquist, Nature, 2005, 435, 765-772.

[5] (a) J. Ghanta, C. -L. Shen, L. L. Kiessling, R. M. Murphy, J. Biol. Chem. 1996, 271, 29525-29528. (b) R. C. Elgersma, T. Meijneke, G. Posthuma, D. T. S. Rijkers, R. M. J. Liskamp, Chem. Eur. J. 2006 12, 3714-3725. (c) J. Sato, T. Takahashi, H. Oshima, S. Matsumura, H. Mihara, Chem. Eur. J. 2007, 13, 7745-7752. (d) R. Mimna, M. -S. Camus, A. Schmid, G. Tuchscherer, H. A. Lashuel, M. Mutter, Angew. Chem. Int. Ed. 2007, 46, 2681-2684.

[6] (a) H. A. Lashuel, S. R. LaBrenz, L. Woo, L. C. Serpell, J. W. Kelly, J. Am. Chem. Soc. 2000, 122, 5262-5277; b) A. Aggeli, I. A. Nyrkova, M. Bell, R. Harding, L. Carrick, T. C. B. McLeish, A. N. Semenov, N. Boden, Proc. Natl. Acad. Sci. U.S.A. 2001, 98, 11857 11862; c) M. López de la Paz, K. Goldie, J. Zurdo, E. Lacroix, C. M. Dobson, A. Hoenger, L. Serrano, Proc. Natl. Acad. Sci. U.S.A. 2002 99, 16052-16057; d) H. A. Behanna, J. J. J. M. Donners, A. C. Gordon, S. I. Stupp, J. Am. Chem. Soc. 2005, 127, 1193-1200; e) S. Deechongkit, E. T. Powers, S. -L. You, J. W. Kelly, J. Am. Chem. Soc. 2005, 127, 8562-8570.

[7] (a) S. K. Maji, D. Haldar, M. G. B. Drew, A. Banerjee, A. K. Das, A. Banerjee, Tetrahedron 2004, 60, 3251-3259. (b) A. Banerjee, A. K. Das, M. G. B. Drew, A. Banerjee, Tetrahedron 2005, 61, 5906-5914. (c) E. Gazit, FEBS J. 2005, 272, 5971-5978.

[8] I. W. Hamley, Angew. Chem. Int. Ed. 2007, 46, 8128-8147.

[9] Molecular Gels: Materials with Self-Assembled Fibrillar Networks; R. G. Weiss, P. Terech, Eds, Kluwer: Norwell, 2005.
[10] Low Molecular Mass Gelators: Design, Self-Assembly, Function; F Fages, Ed., Topics in Current Chemistry Series, Springer-Verlag: New York, 2005.

[11] (a) P. Terech, R. G. Weiss, Chem. Rev. 1997, 97, 3133-3159. (b) D. J. Abdallah, R. G. Weiss, Adv. Mater. 2000, 12, 1237-1247. (c) J. van Esch, B. L. Feringa, Angew. Chem., Int. Ed. 2000, 39, 2263-2354. (f) O. Gronwald, E. Snip, S. Shinkai, Curr. Opin. Colloid Interface Sci. 2002, 7, 148-156. (d) L. A. Estroff, A. D. Hamilton, Chem. Rev. 2004, 104, 1201-1207. (e) A. R. Hirst, D. K. Smith, Chem. Eur. J. 2005, 11, 5496-5508.

[12] (a) B. Escuder, S. Martí, J. F. Miravet, Langmuir 2005, 21, 6776 6787. (b) J. F. Miravet, B. Escuder, Chem. Commun. 2005, 57965798.

[13] B. Escuder, J. F. Miravet, Langmuir 2006, 22, 7793-7797.

[14] P. I. Haris, D. Chapman, Biopol. Pept. Sci. 1995, 37, 251-263.

[15] Circular Dichroism of Peptides and Proteins, in Circular Dichroism: Principles and Applications; N. Sreerama, R. Woody, (Eds.: N. Berova, K. Nakanishi, R. W. Woody,); Wiley: New York, 2000.

[16] Sangappa, S. S.Mahesh, R. J. Somashekar, Biosci. 2005, 30, 259-268.

[17] U. Slotta, S. Hess, K. Spieb, T. Stromer, L. Serpell, T. Scheibel, Macromol. Biosci. 2007, 7, 183-188.

[18] a) M. J. Pandya, G. M. Spooner, M. Sunde, J. R. Thorpe, A. Rodger, D. N. Woolfson, Biochemistry 2000, 39, 8728-8734. b) S. Ramachandran, J. Trewhella, Y. Tseng, Y. B. Yu, Chem. Mater. 2006, 18, 6157-6162.

[19] T. J. Deming, Soft Matter 2005, 1, 28-35.

[20] M. Minguet, D. B. Amabilino, K. Wurst, J. Veciana, J. Chem. Soc. Perkin Trans. 2, 2001, 670-676.

Received: ((will be filled in by the editorial staff)) Published online: ((will be filled in by the editorial staff)) 


\section{Entry for the Table of Contents}

Biomimetic gels

Using a silk peptidic sequence Gly-AlaGly-Ala as a core, self-assembling tetrapeptides have been constructed and their aggregation process has been controlled by modulation of the length of alkyl terminal groups.

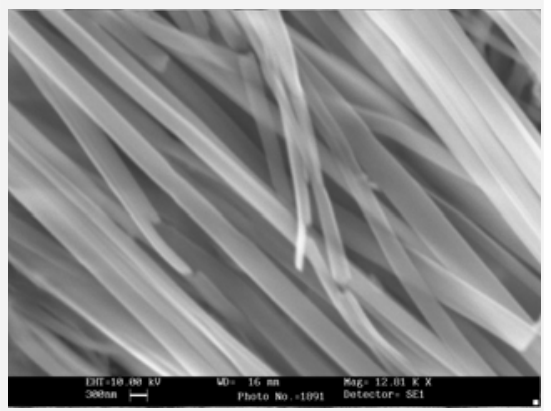

Sajid Iqbal, Juan F. Miravet*, Beatriu Escuder*Page No. - Page No.

Biomimetic Self-assembly of Tetrapeptides into Fibrillar Networks and Organogels

Keywords: self-assembly / gels / silk / $\beta$-sheet / fibers. 
Biomimetic Self-assembly of Tetrapeptides into Fibrillar Networks and Organogels

Sajid Iqbal, Juan F. Miravet* and Beatriu Escuder*

Departament de Química Inorgànica i Orgànica, Universitat Jaume I, 12071 Castelló, Spain escuder@qio.uji.es

\section{Supporting Information}

Circular Dichroism

X-Ray Powder Diffraction

FT-IR

${ }^{1} \mathrm{H}$ and ${ }^{13} \mathrm{C}$ NMR page 2

page 11

page 20

page 23 


\section{Compound 5}

\section{CIRCULAR DICHROISM}

\section{DME}

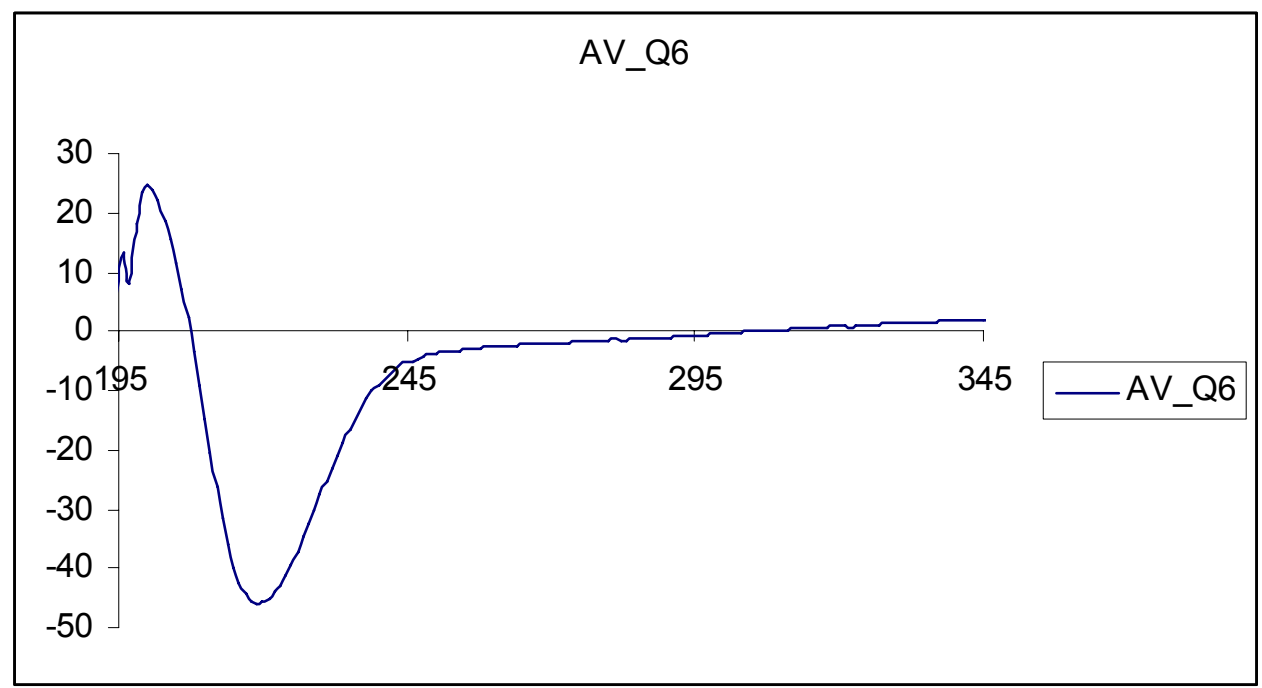

2-propanol

AV_Q2

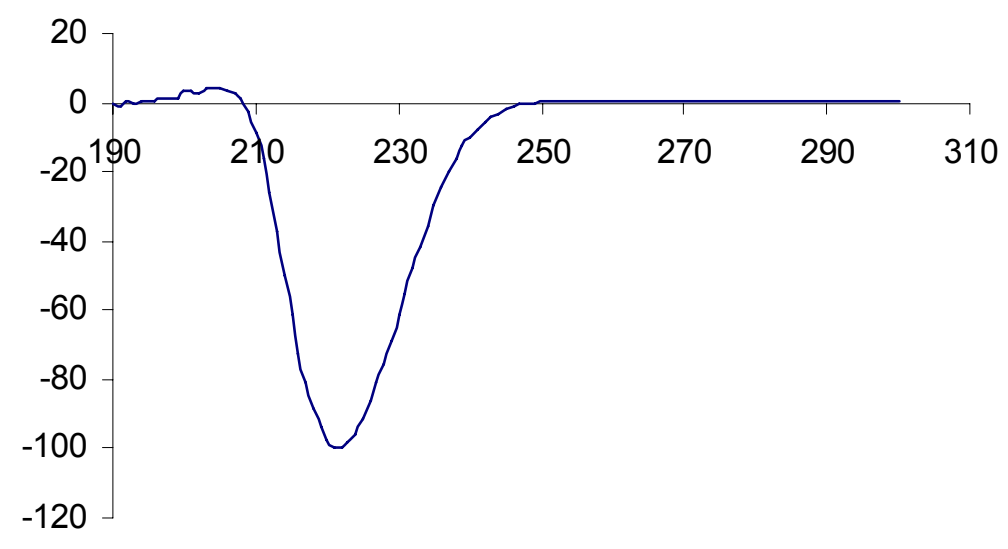

Acetonitrile

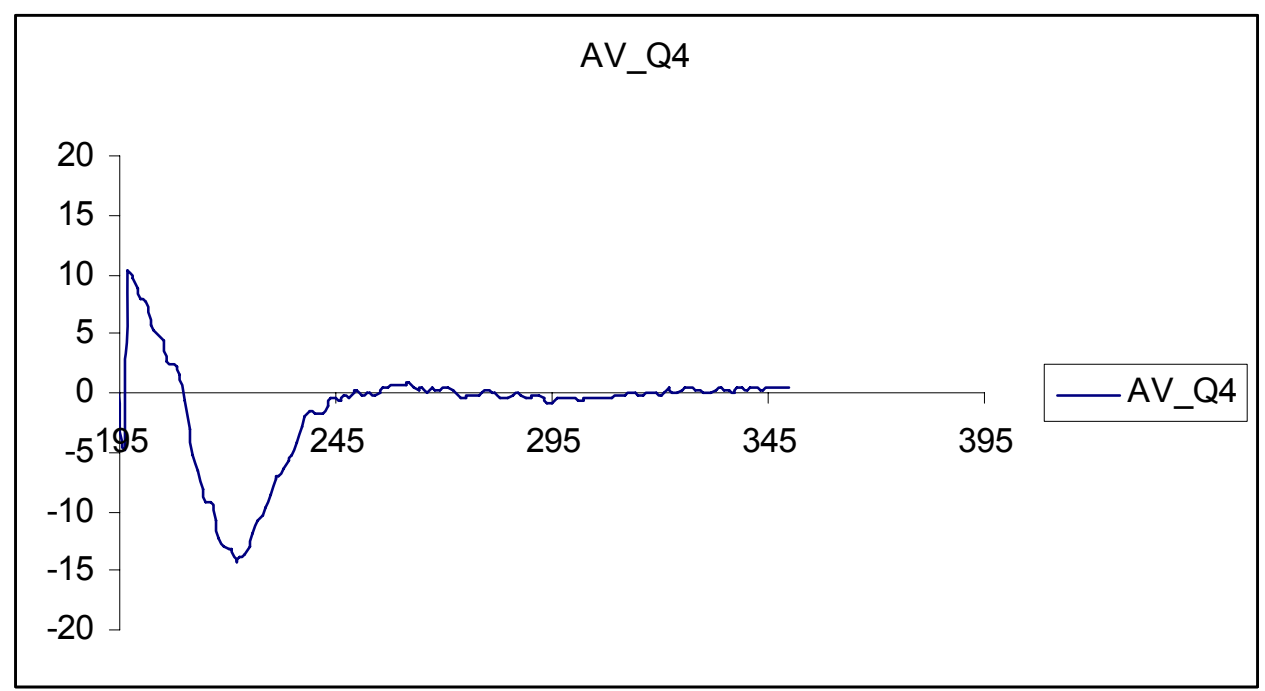


Toluene

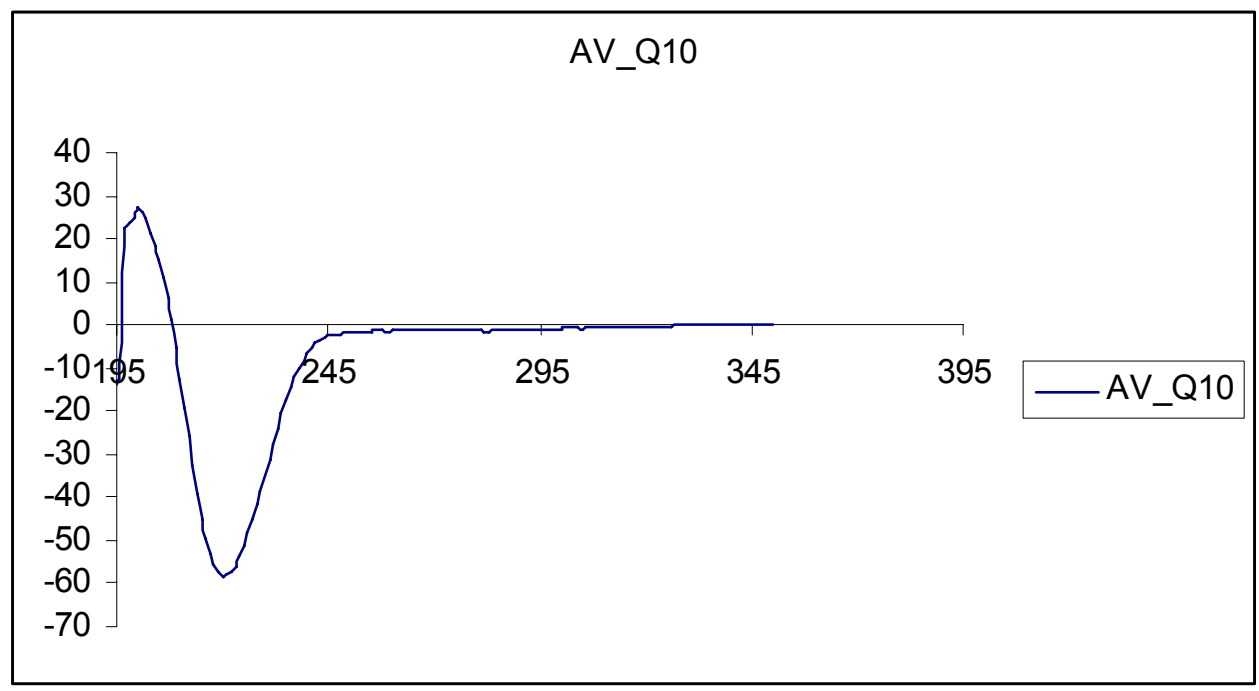

\section{Compound 6}

Methanol

AV_Y1

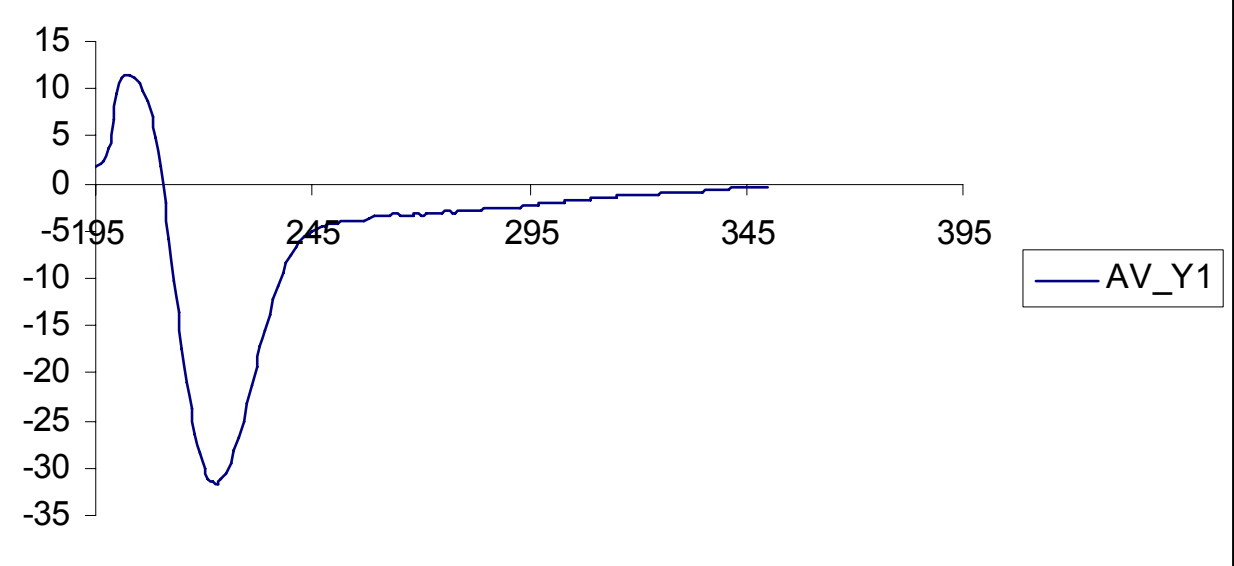

2-propanol

$$
\text { AV_Y2 }
$$

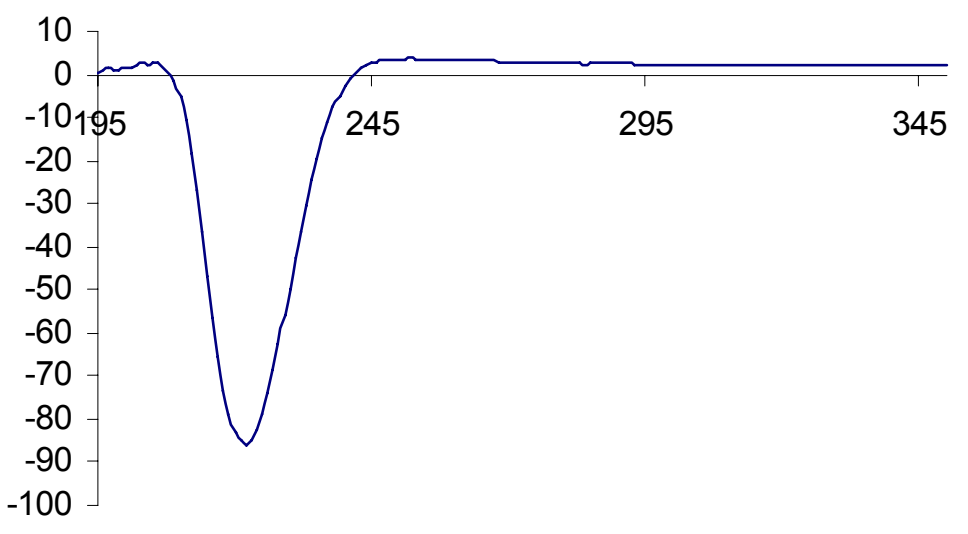


Acetonitrile

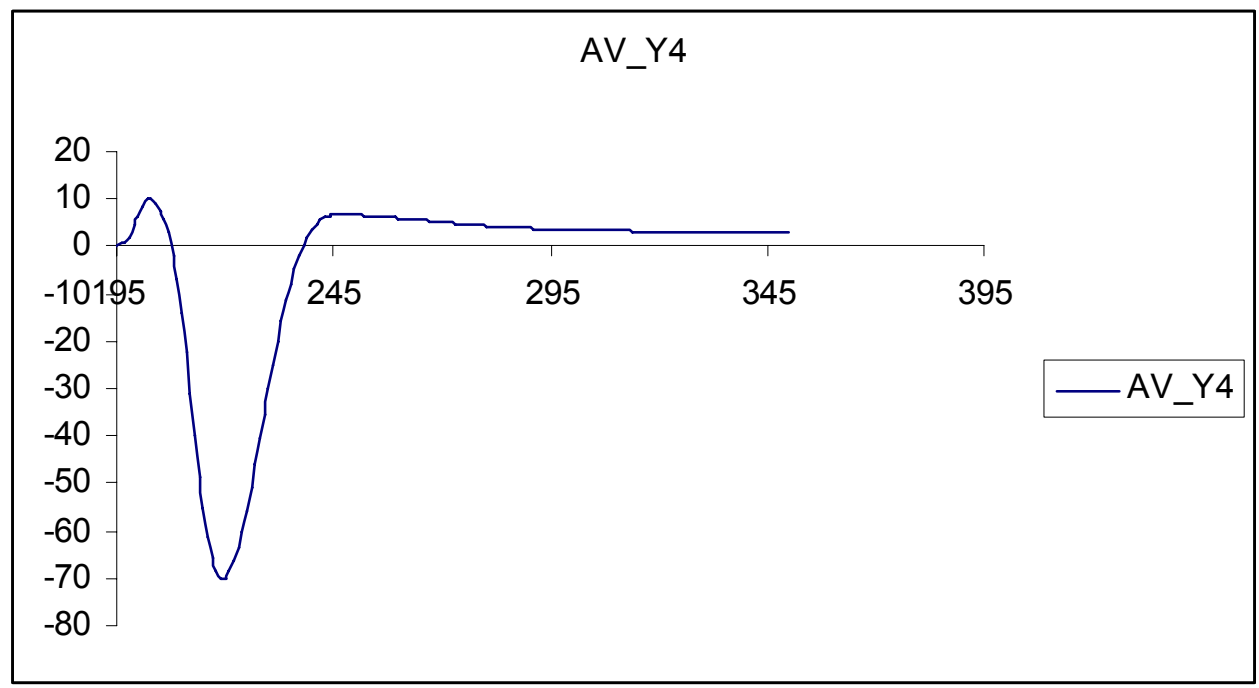

Ethanol

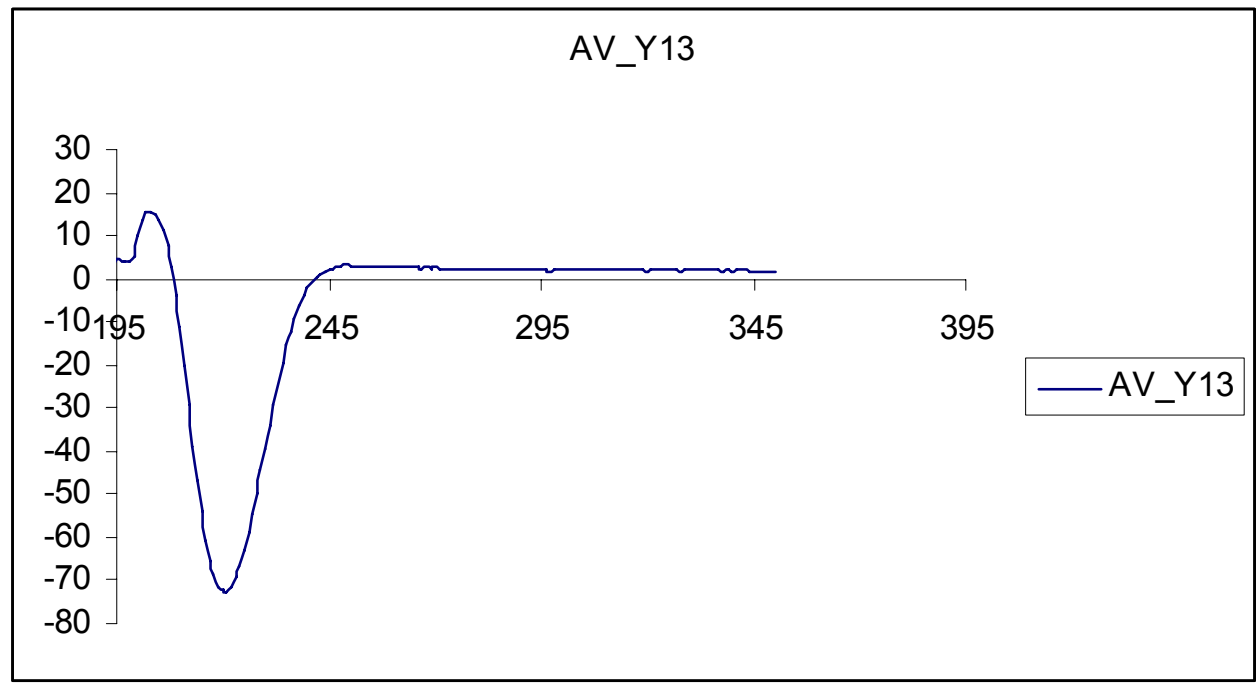

\section{Compound 7}

Chloroform

$$
\text { AV_P7 }
$$

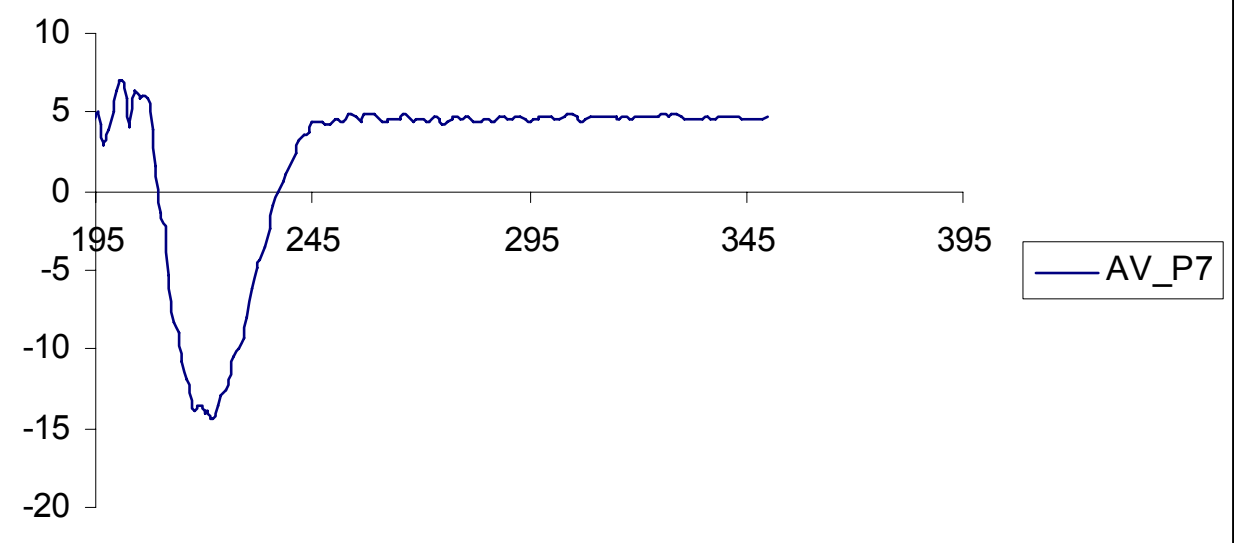




\section{Compound 8}

Acetonitrile

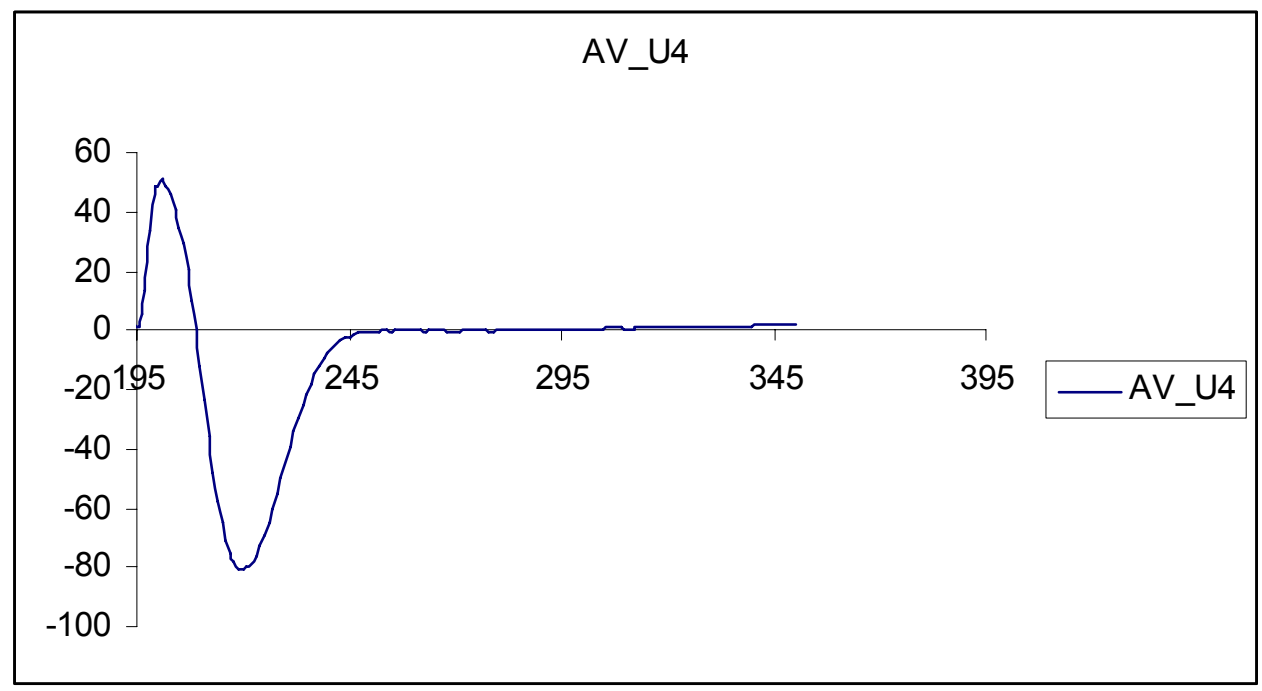

Toluene

$$
\text { AV_U10 }
$$

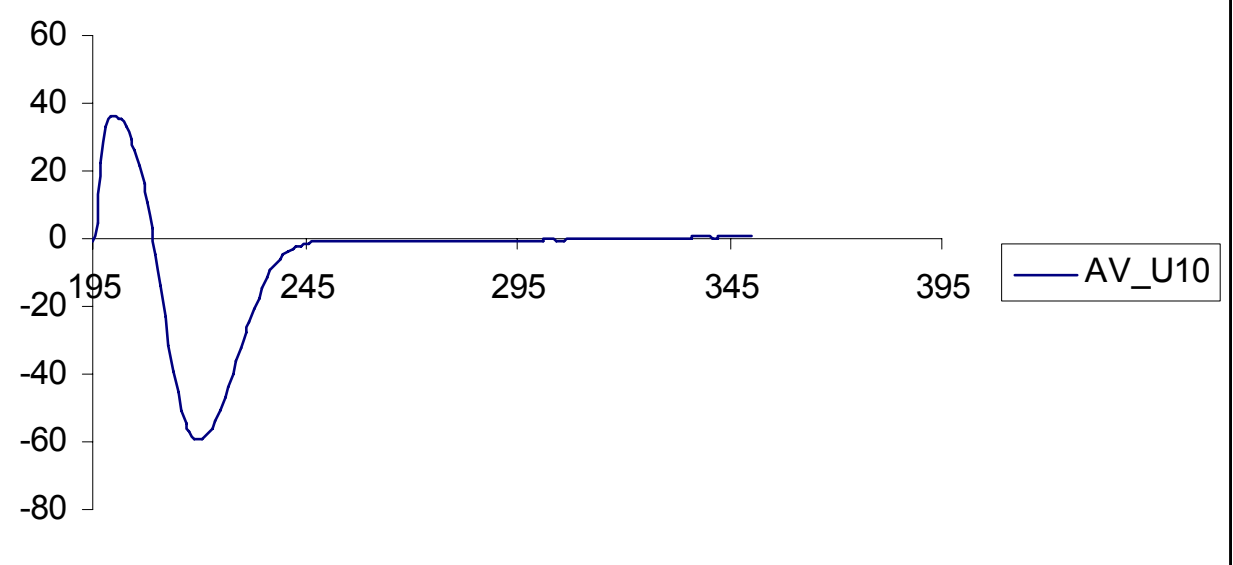

Cyclohexanol

$$
\text { AV_U12 }
$$

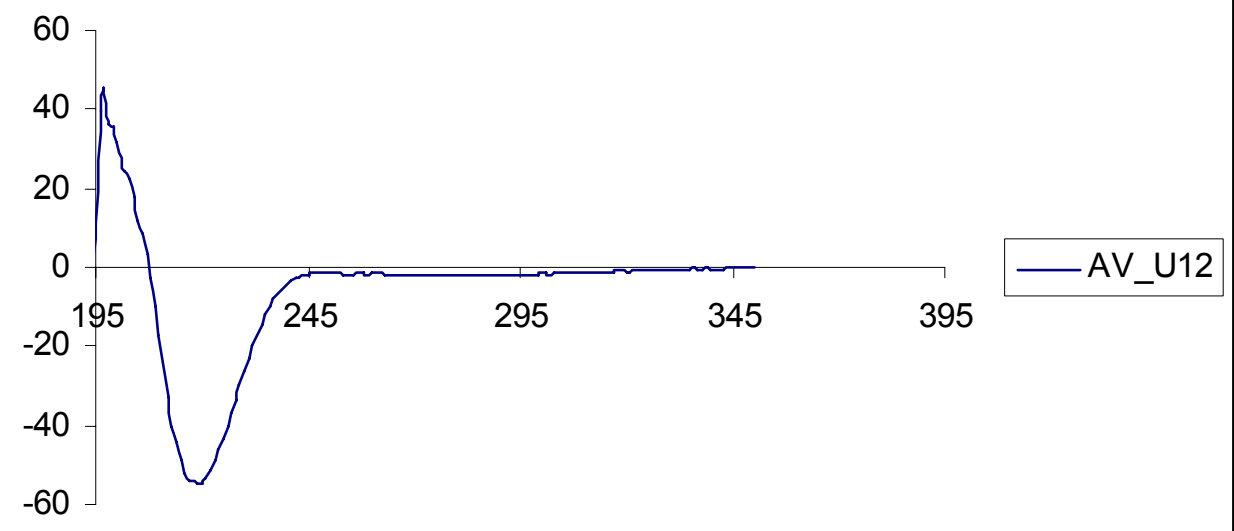




\section{2-propanol}

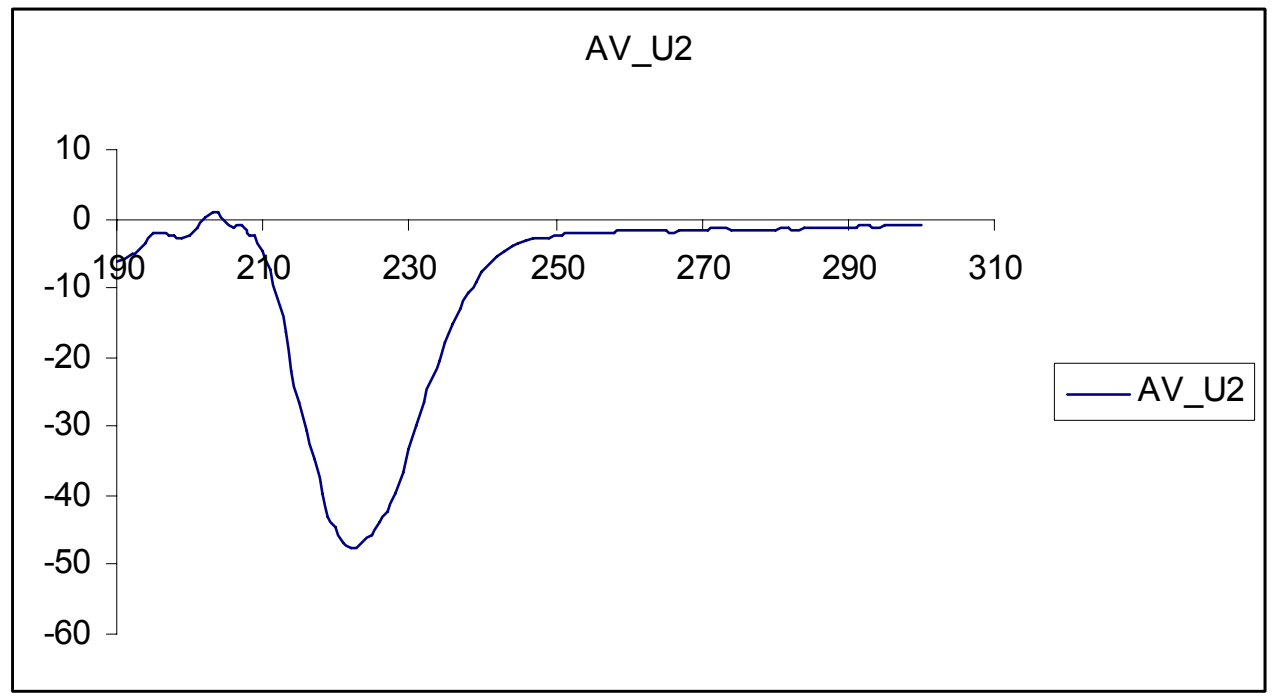

\section{Compound 9}

Acetonitrile

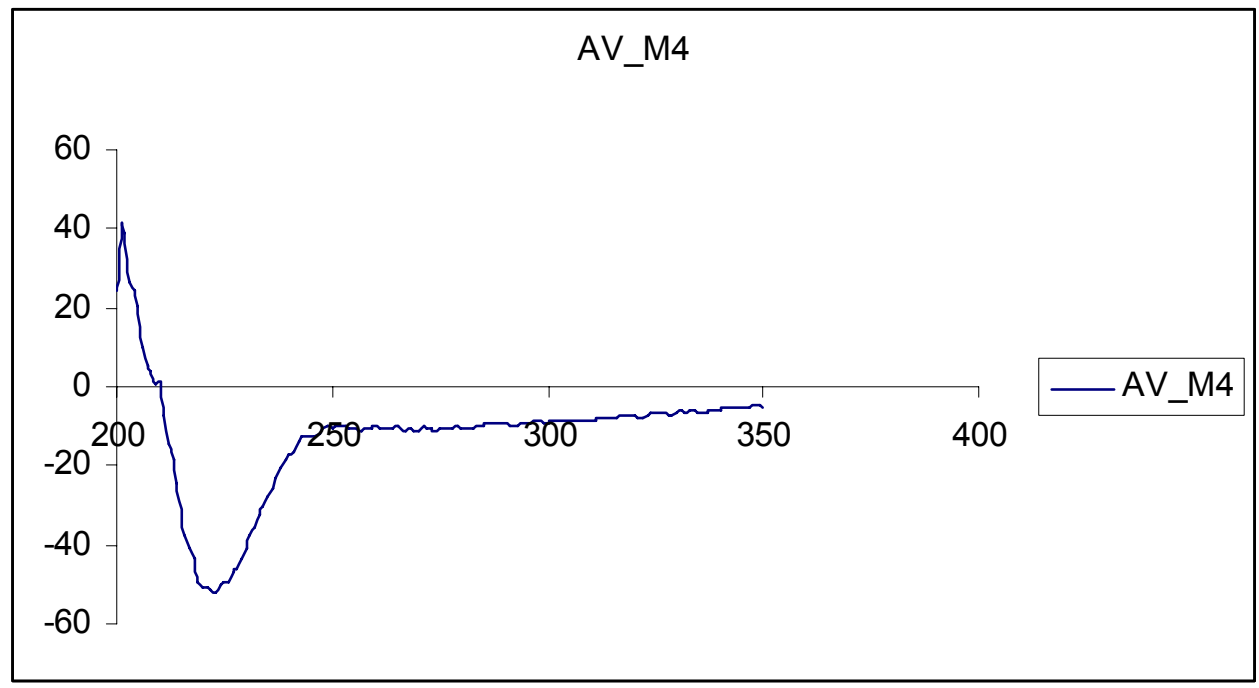

Toluene

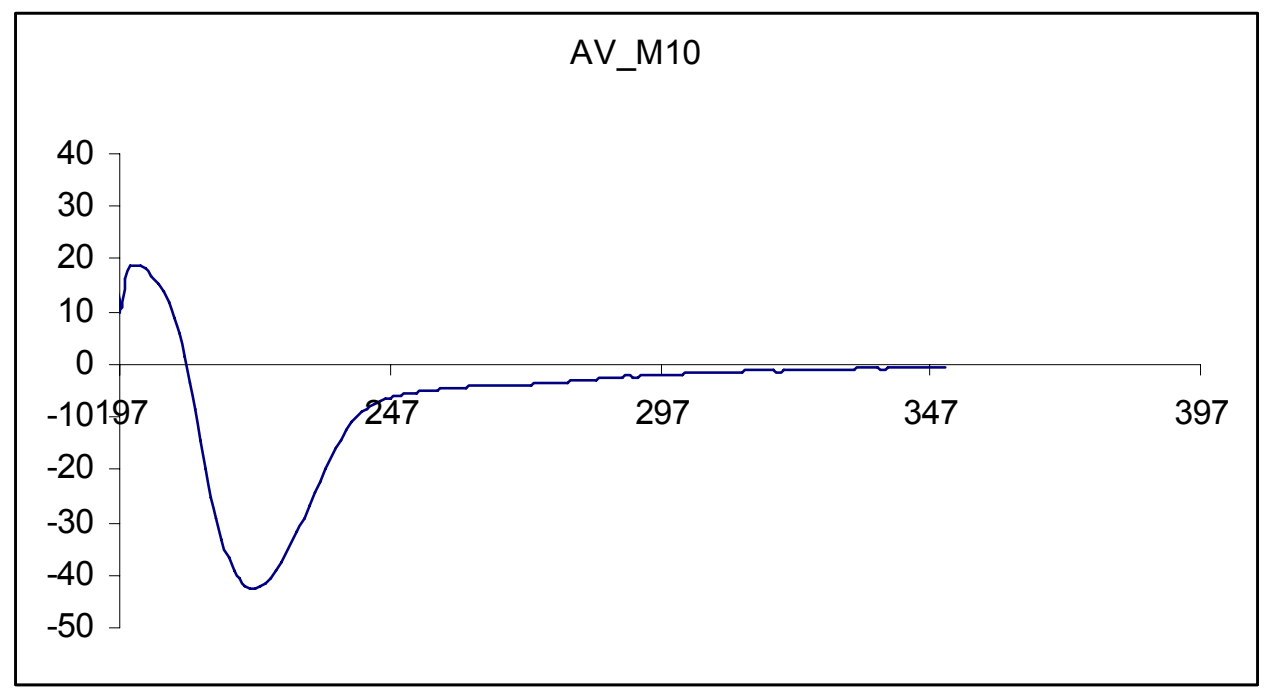


Methanol

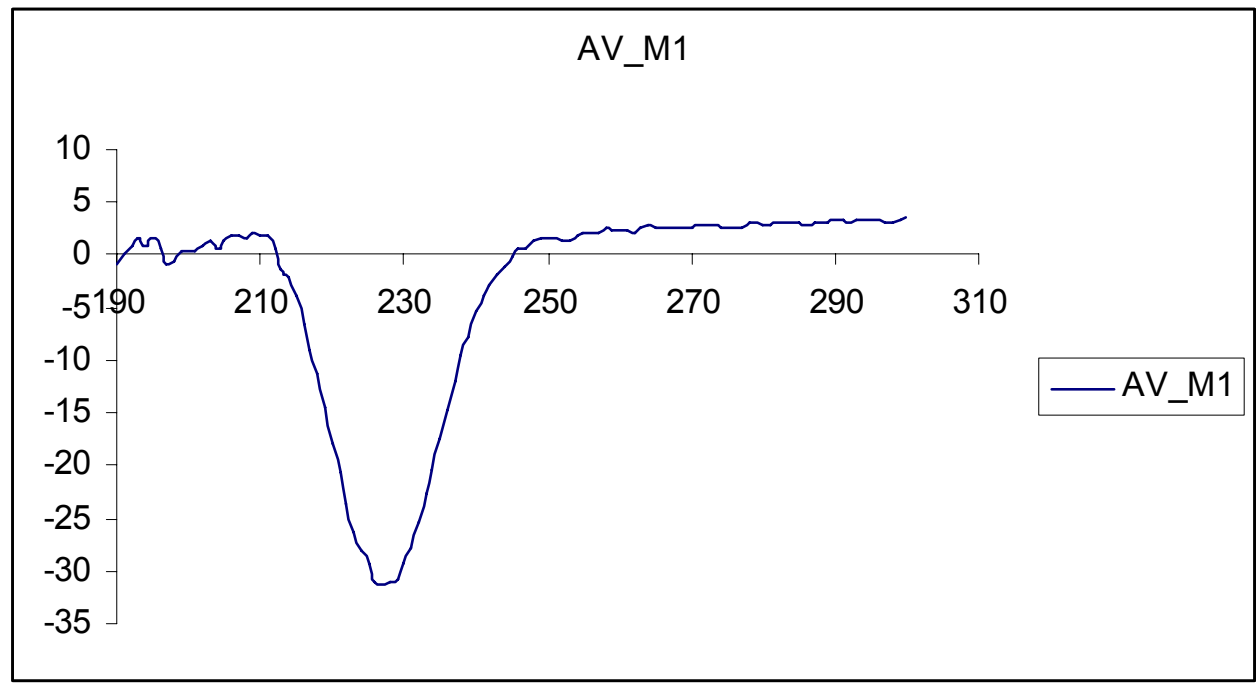

\section{Compound 10}

2-propanol

$$
\text { AV_V2 }
$$

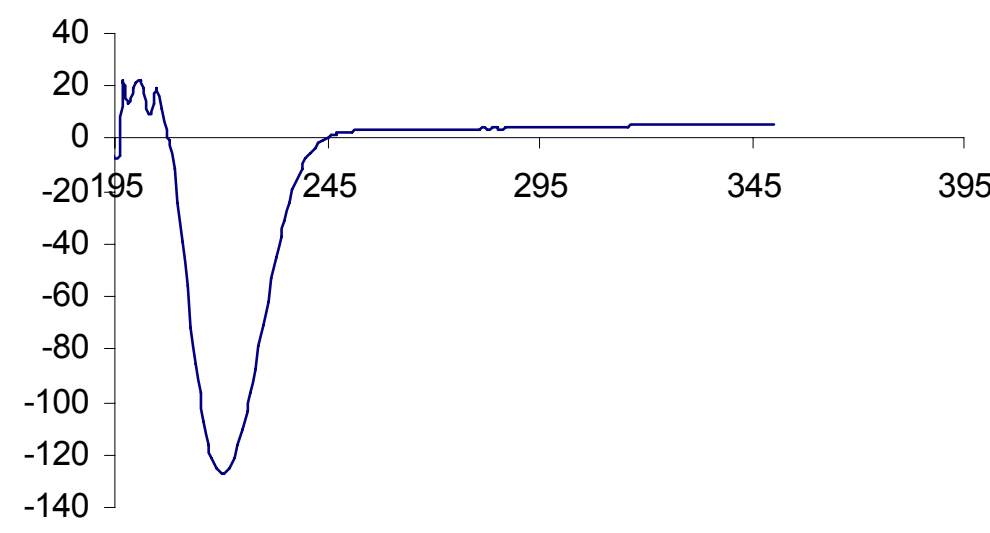

Acetonitrile

$$
\text { AV_V4 }
$$

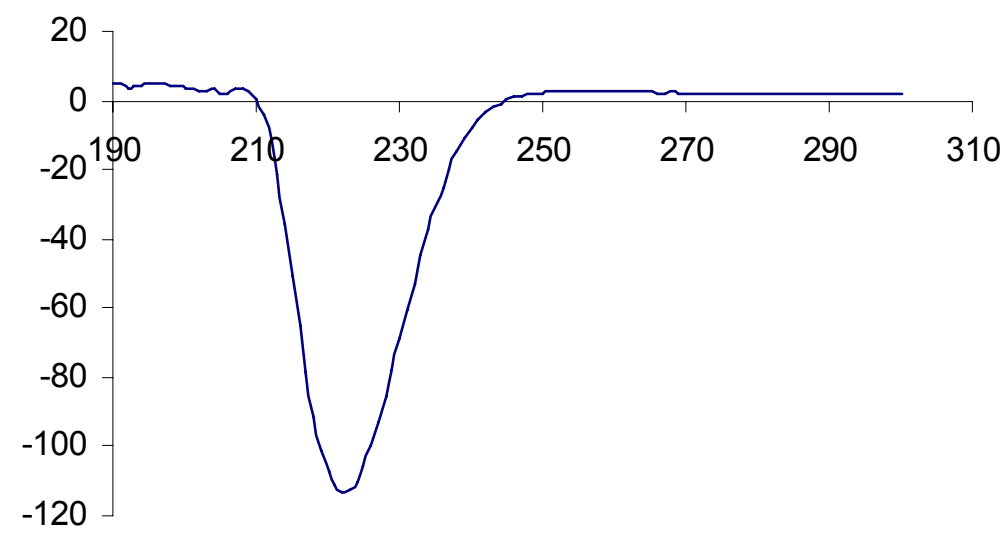


Toluene

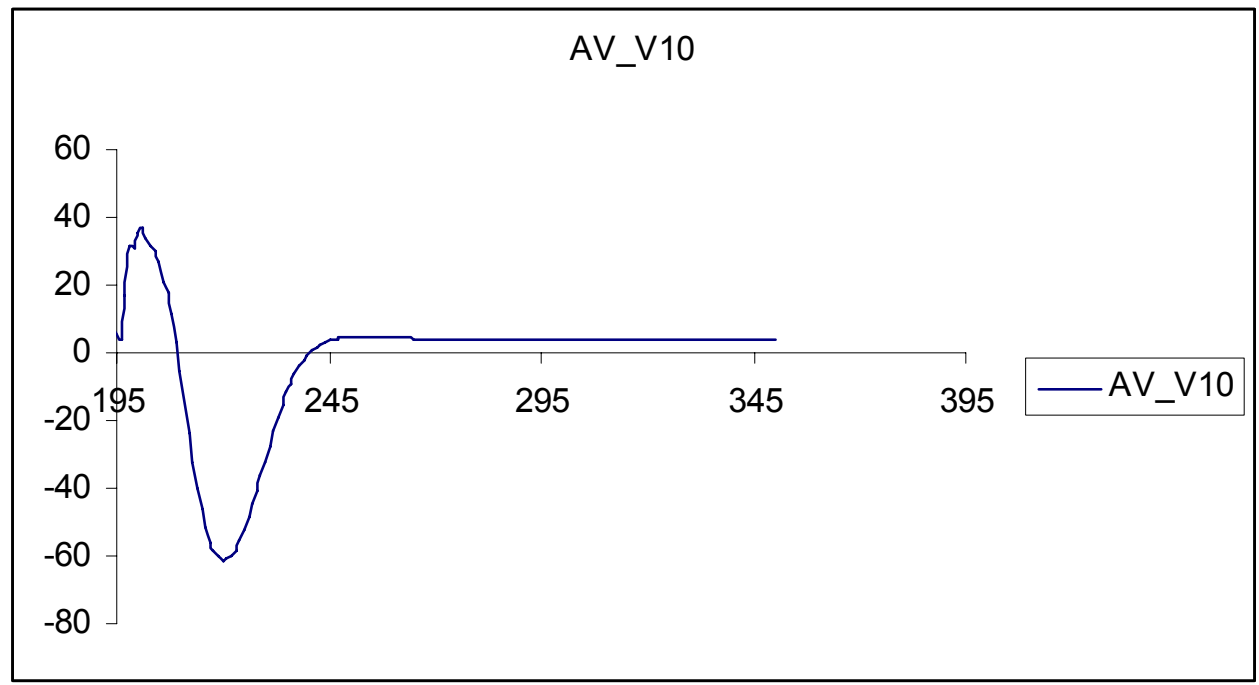

Cyclohexanol

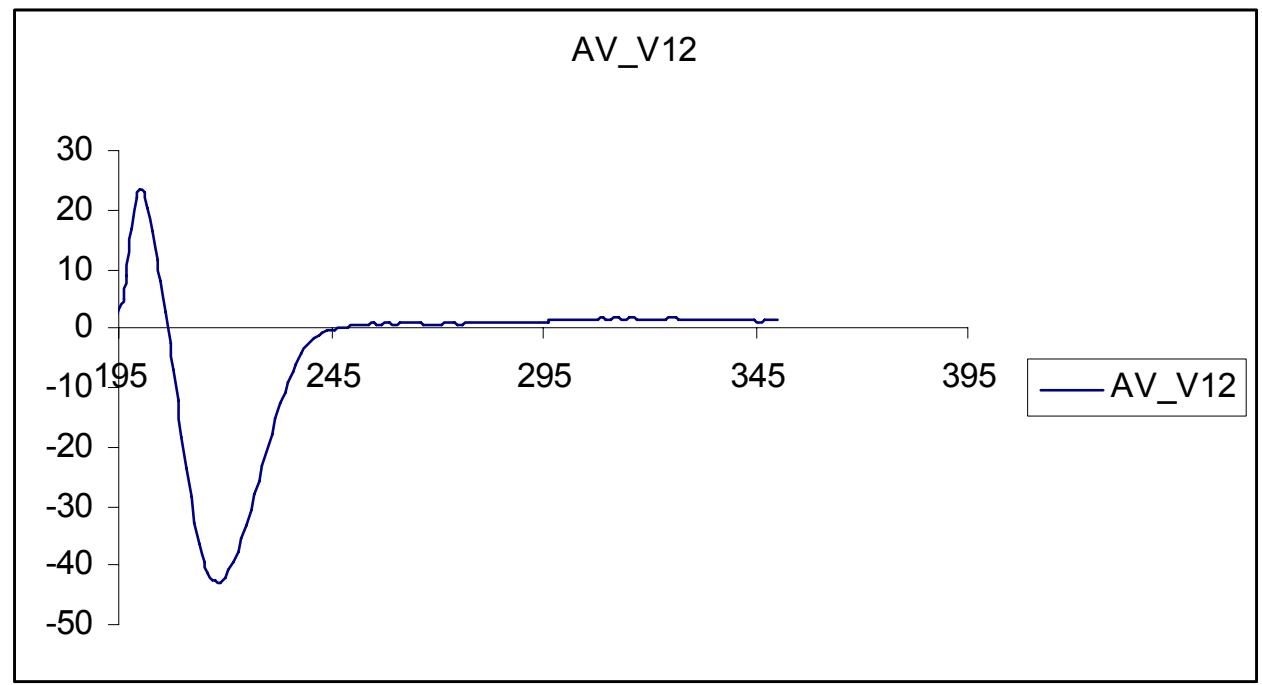

\section{Compound 11}

\section{Toluene}

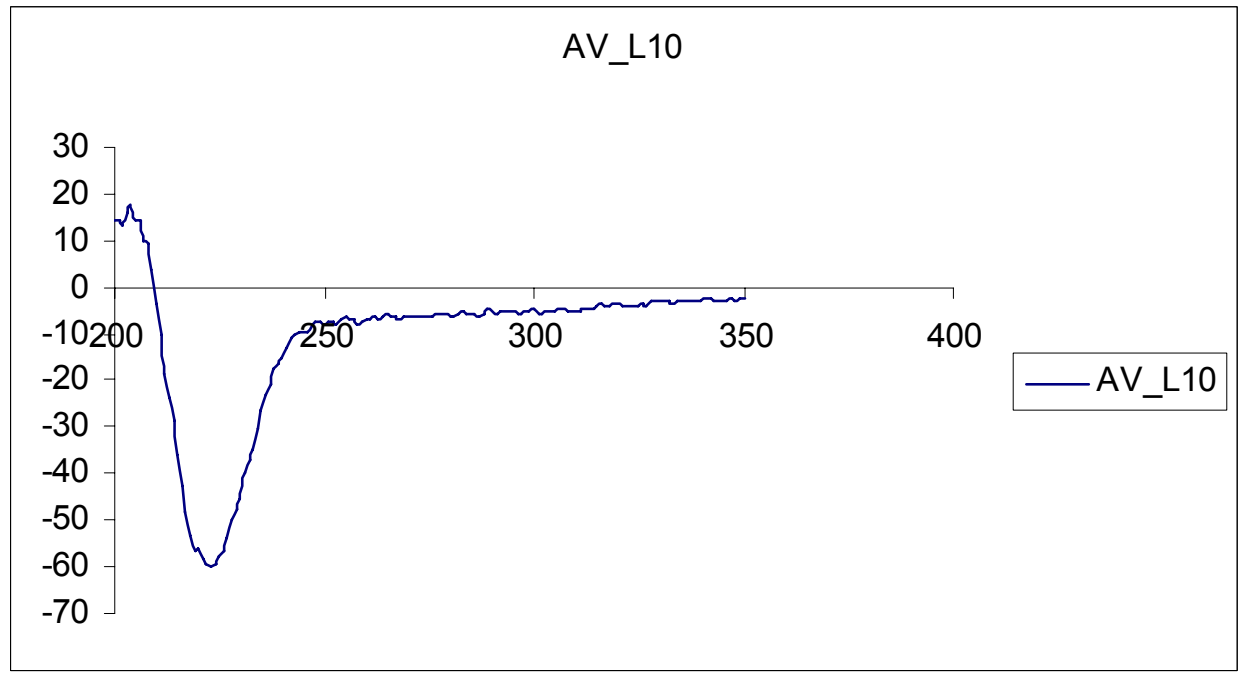


Chloroform

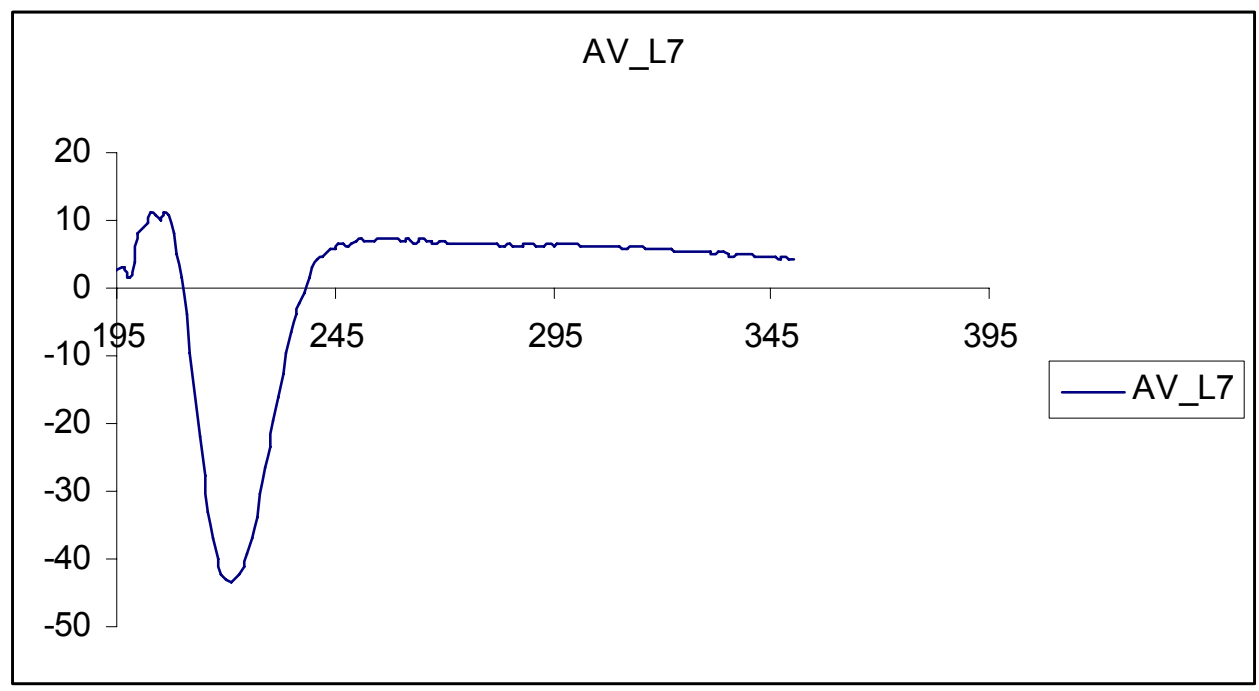

Compound 12

Methanol

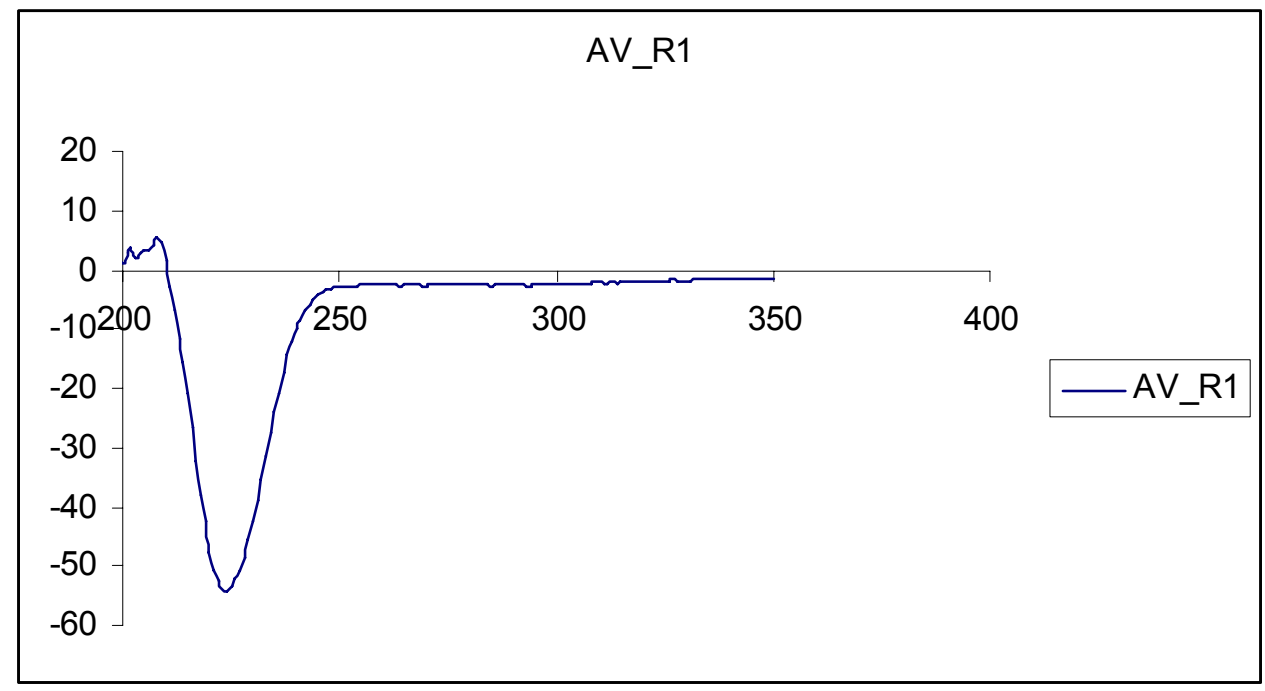

2-propanol

$$
\text { AV_R2 }
$$

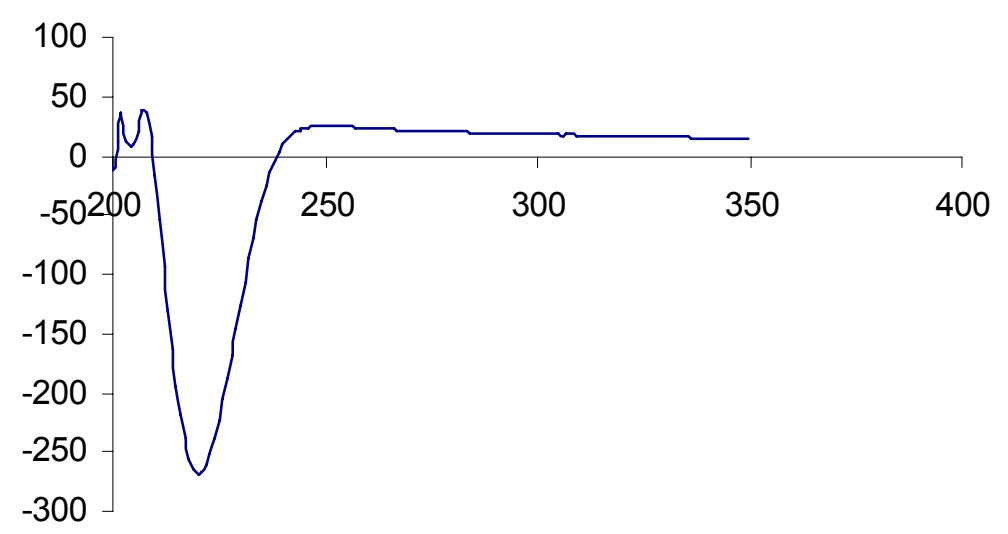




\section{Acetonitrile}

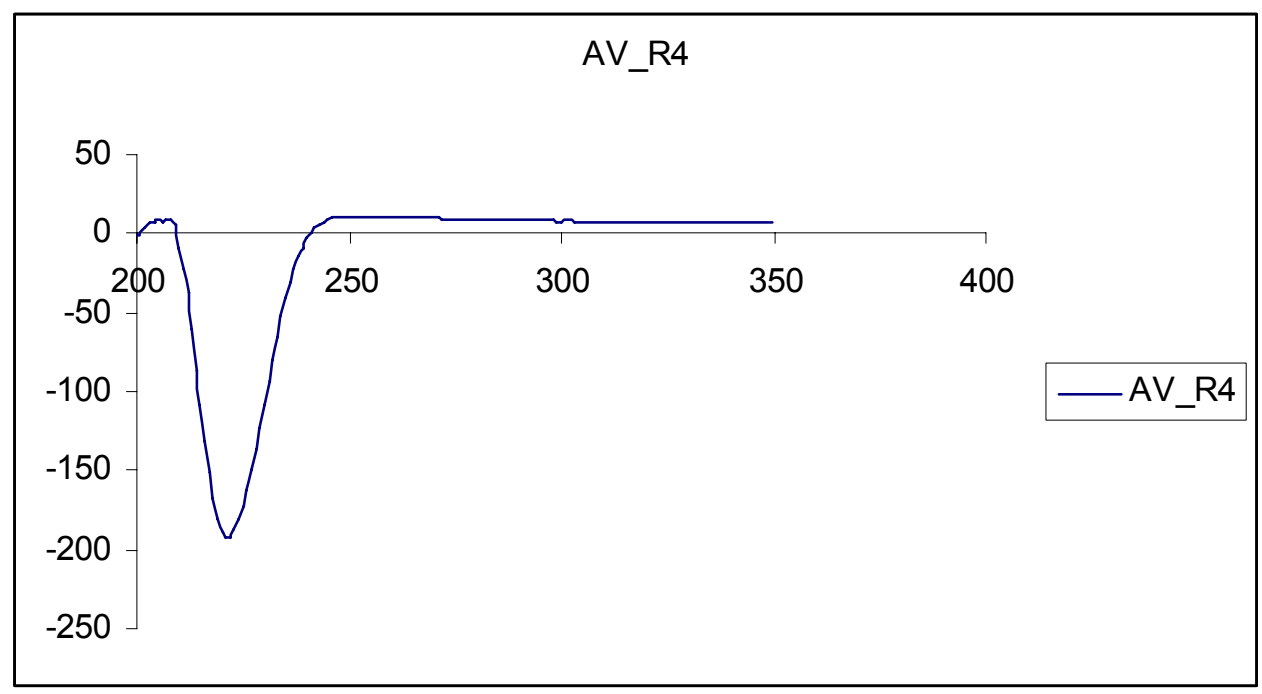




\section{X-Ray Powder Diffraction}

Table S1. Cell dimensions $(\AA)$ derived from powder diffraction data of xerogels.

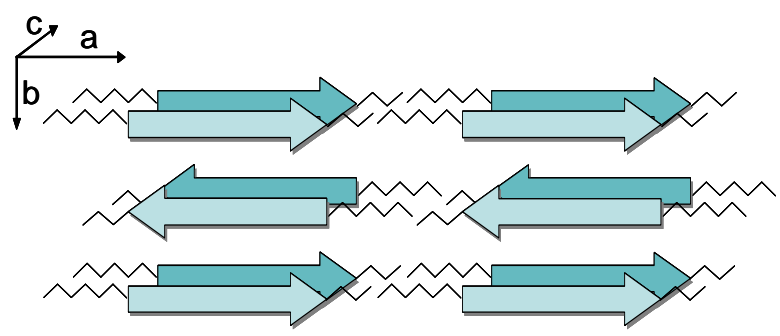

\begin{tabular}{|c|c|c|c|c|}
\hline Compound $^{[\mathrm{a}]}$ & Solvent $^{[\mathrm{b}]}$ & $\mathbf{a}$ & b & c \\
\hline $\begin{array}{c}\mathbf{5} \\
(30)\end{array}$ & $\begin{array}{l}\mathrm{CH}_{3} \mathrm{CN} \\
\text { 2-Propanol } \\
\text { Toluene } \\
\text { Methanol } \\
\text { DME } \\
\text { THF }\end{array}$ & $\begin{array}{l}30.4 \\
30.7 \\
29.6 \\
30.5 \\
30.6 \\
30.2\end{array}$ & $\begin{array}{l}8.5 \\
- \\
8.5 \\
8.5 \\
8.5 \\
8.5\end{array}$ & $\begin{array}{l}4.4 \\
4.5 \\
4.4 \\
4.4 \\
4.4 \\
4.4\end{array}$ \\
\hline $\begin{array}{c}\mathbf{6} \\
(23)\end{array}$ & $\begin{array}{l}\mathrm{CH}_{3} \mathrm{CN} \\
\text { 2-Propanol } \\
\text { Ethanol } \\
\text { Toluene } \\
\text { Methanol } \\
\text { THF } \\
\end{array}$ & $\begin{array}{l}23.8 \\
23.0 \\
24.5 \\
23.1 \\
23.9 \\
23.8 \\
\end{array}$ & & $\begin{array}{l}4.5 \\
4.4 \\
4.5 \\
4.5 \\
4.5 \\
4.5 \\
\end{array}$ \\
\hline $\begin{array}{c}7 \\
(38)\end{array}$ & $\begin{array}{l}\mathrm{CH}_{3} \mathrm{CN} \\
\text { 2-Propanol } \\
\text { CHCl3 } \\
\text { THF } \\
\text { Toluene }\end{array}$ & $\begin{array}{l}39.4 \text { (broad) } \\
38.7 \text { (broad) } \\
36.8 \\
38.3 \\
37.7 \text { (broad) }\end{array}$ & $\begin{array}{l}11.3 \\
11.3 \\
- \\
11.3 \\
11.3\end{array}$ & $\begin{array}{l}4.5 \\
4.5 \\
4.5 \\
4.5 \\
4.4\end{array}$ \\
\hline $\begin{array}{c}8 \\
(34.5)\end{array}$ & $\begin{array}{l}\mathrm{CH}_{3} \mathrm{CN} \\
\text { 2-Propanol } \\
\text { Toluene } \\
\text { Methanol } \\
\text { Cyclohexanol }\end{array}$ & $\begin{array}{l}30.5 \\
34.0 \\
33.9 \\
34.3 \\
33.8\end{array}$ & $\begin{array}{l}- \\
11.5 \\
11.6 \\
11.6 \\
-\end{array}$ & $\begin{array}{l}4.4 \\
4.5 \\
4.5 \\
4.5 \\
4.5\end{array}$ \\
\hline $\begin{array}{c}\mathbf{9} \\
(38)\end{array}$ & $\begin{array}{l}\mathrm{CH}_{3} \mathrm{CN} \\
\text { 2-Propanol } \\
\text { Toluene } \\
\text { Methanol } \\
\text { THF }\end{array}$ & $\begin{array}{l}37.2 \\
37.5 \\
37.4 \\
37.7 \\
37.9\end{array}$ & $\begin{array}{l}- \\
- \\
11.6 \\
- \\
-\end{array}$ & $\begin{array}{l}4.5 \\
4.5 \\
4.5 \\
4.5 \\
4.5\end{array}$ \\
\hline $\begin{array}{c}\mathbf{1 0} \\
(27)\end{array}$ & $\begin{array}{l}\mathrm{CH}_{3} \mathrm{CN} \\
\text { 2-Propanol } \\
\text { Toluene } \\
\text { Methanol } \\
\text { Cyclohexanol }\end{array}$ & $\begin{array}{l}26.9 \\
26.3 \\
26.6 \\
27.0 \\
26.9\end{array}$ & $\begin{array}{l}8.5 \\
8.5 \\
8.5 \\
8.5 \\
-\end{array}$ & $\begin{array}{l}4.5 \\
4.5 \\
4.5 \\
4.5 \\
4.5\end{array}$ \\
\hline $\begin{array}{c}\mathbf{1 1} \\
(34.5)\end{array}$ & $\begin{array}{l}\text { Toluene } \\
\mathrm{CHCl}_{3}\end{array}$ & $\begin{array}{l}32.7 \\
31.8\end{array}$ & $\begin{array}{l}11.3 \\
11.0\end{array}$ & $\begin{array}{l}4.5 \\
-\end{array}$ \\
\hline $\begin{array}{c}\mathbf{1 2} \\
(27)\end{array}$ & $\begin{array}{l}\mathrm{CH}_{3} \mathrm{CN} \\
\text { 2-Propanol } \\
\text { Methanol }\end{array}$ & $\begin{array}{l}26.8 \\
26.7 \\
26.3\end{array}$ & $\begin{array}{l}8.4 \\
- \\
8.4\end{array}$ & $\begin{array}{l}4.5 \\
4.4 \\
4.5\end{array}$ \\
\hline
\end{tabular}

${ }^{[a]}$ Calculated extended molecular length in parenthesis. ${ }^{[b]}$ Xerogels were prepared by deposition of the gel on top of a glass slide and fast vacuum evaporation of the corresponding solvent. Although some extent of drying effects cannot be discarded, the slight solvent dependence of $a$ in contrast with the independence of $b$ and $c$ for a given sample seems to indicate that those does not play a significant role on the observed general trends. 


\section{Compound 5}
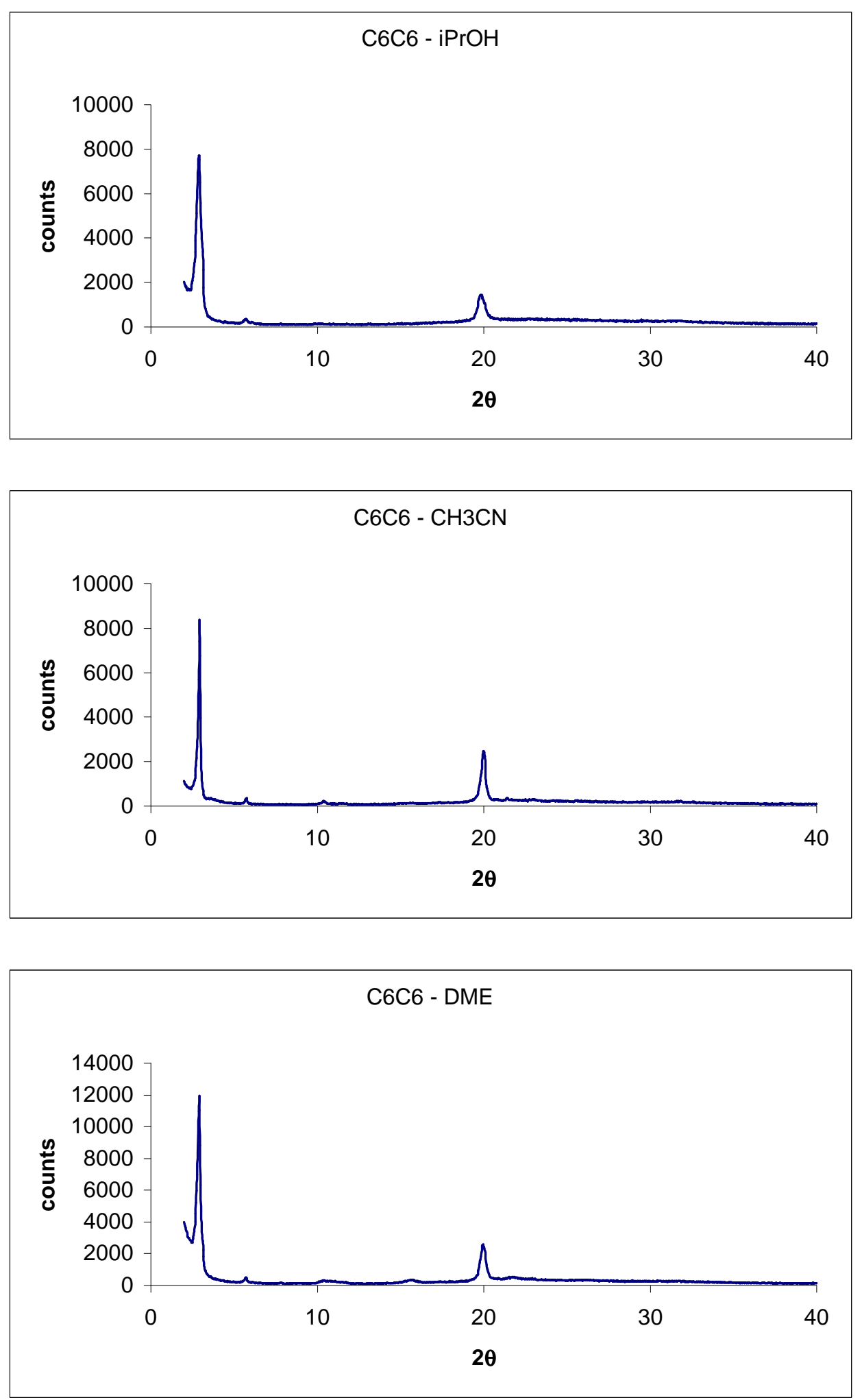


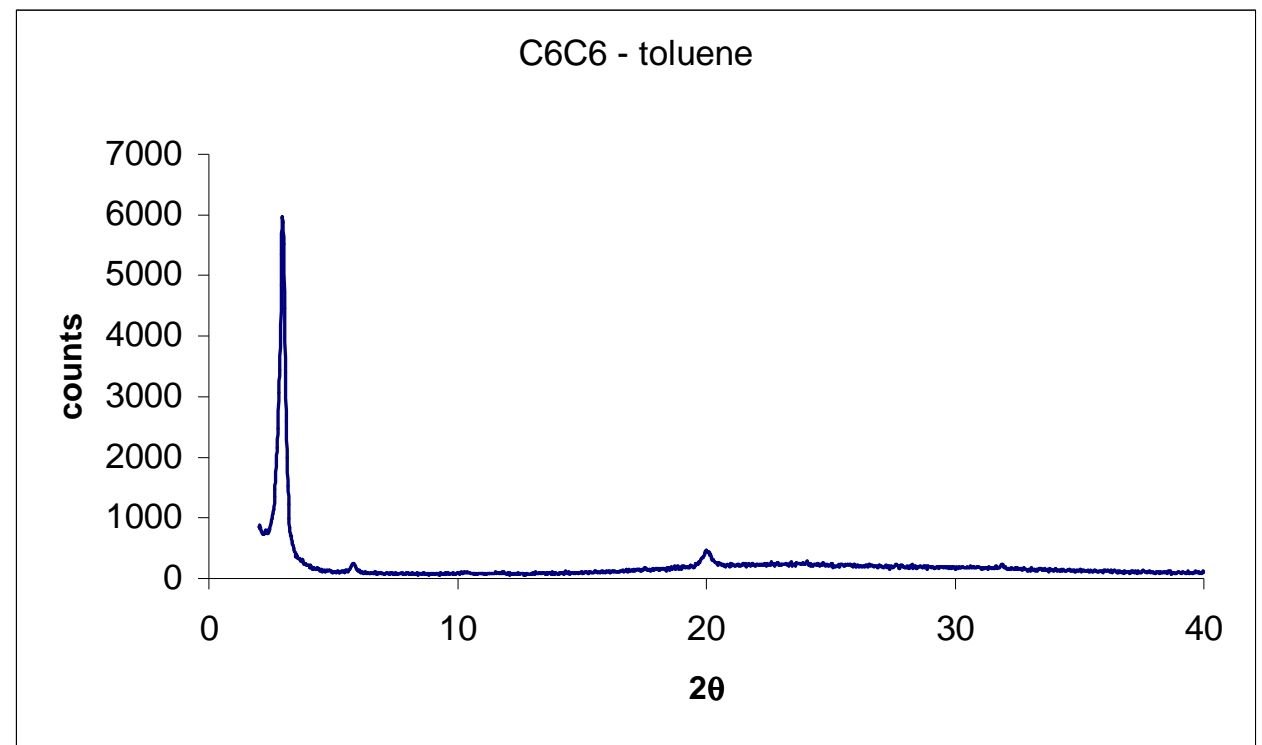

Compound 6
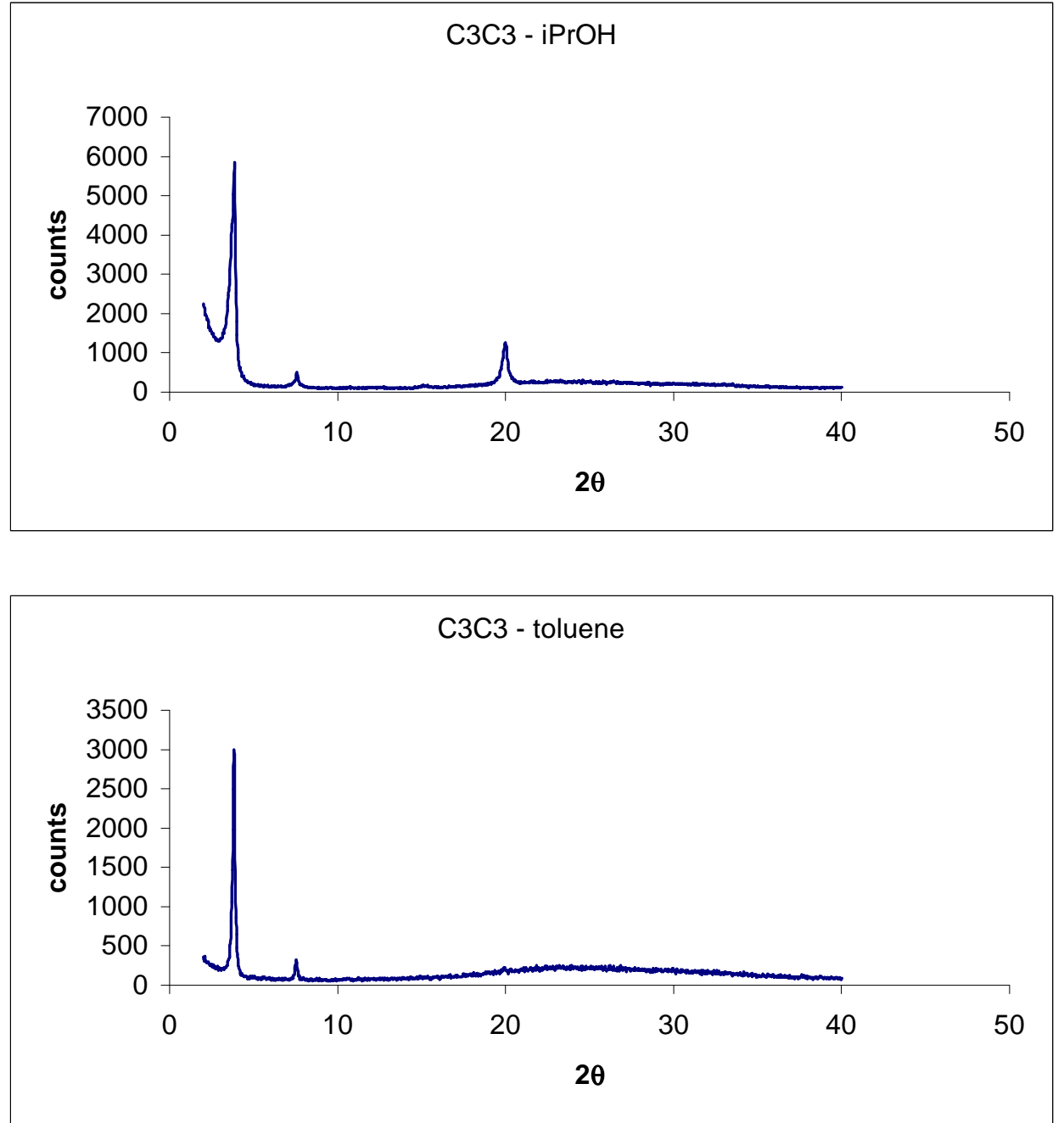


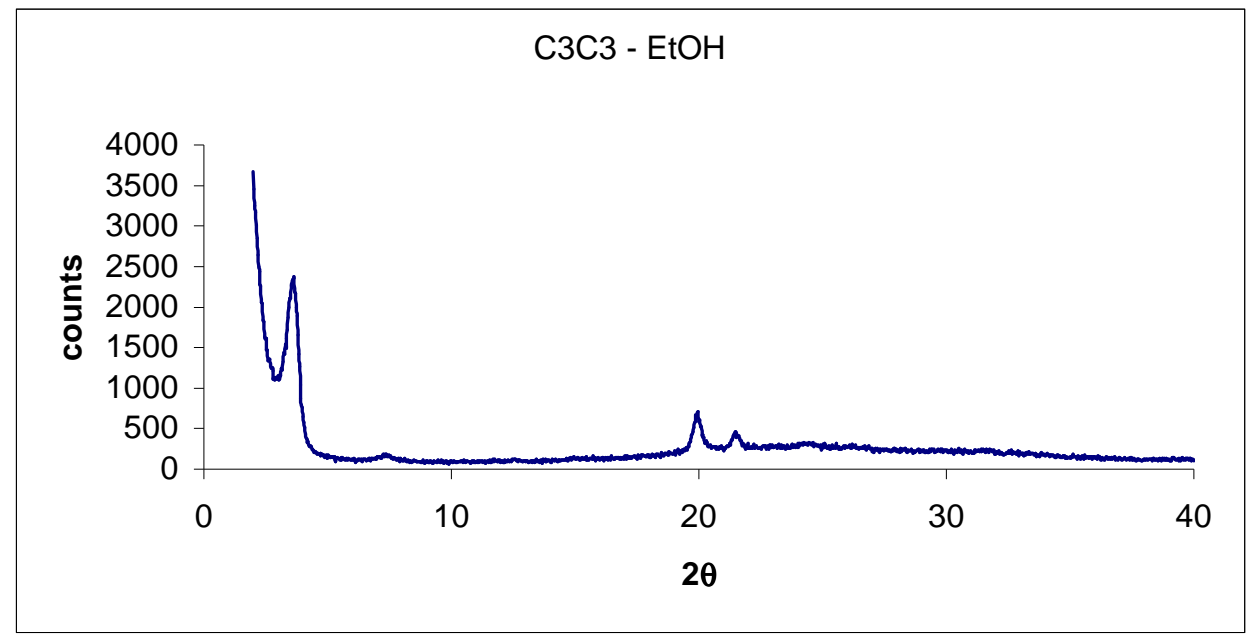

Compound 8
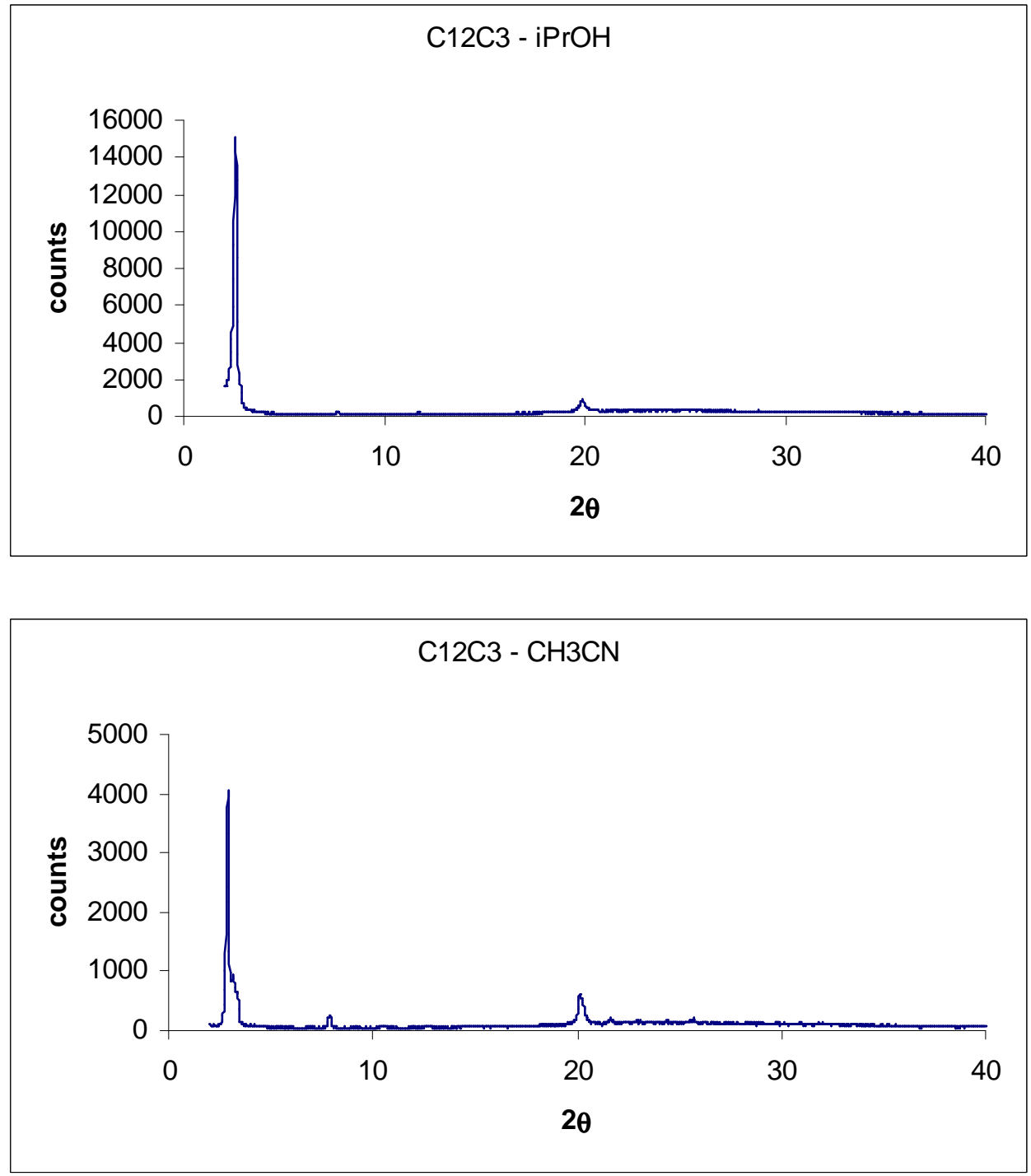

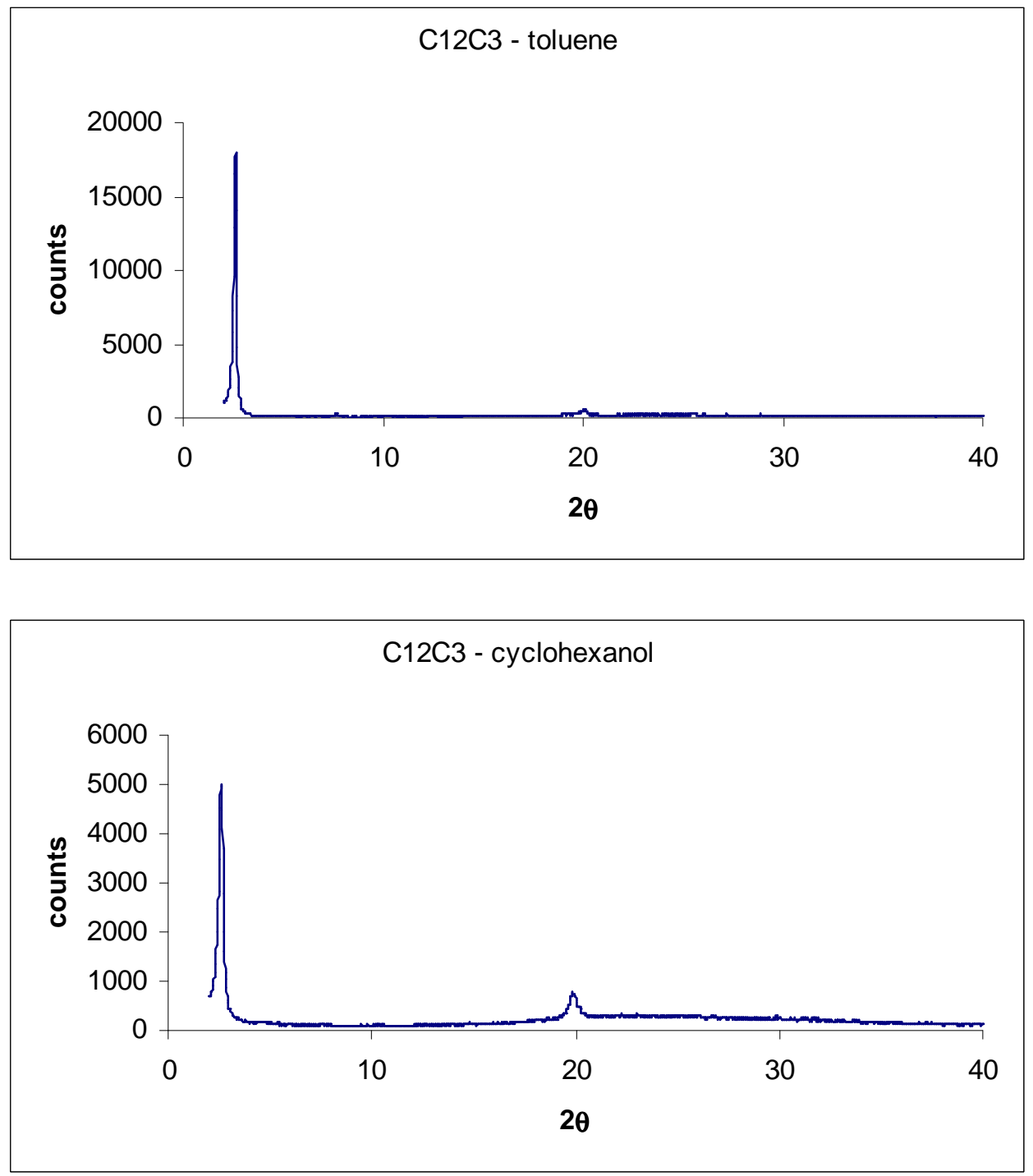

\section{Compound 9}

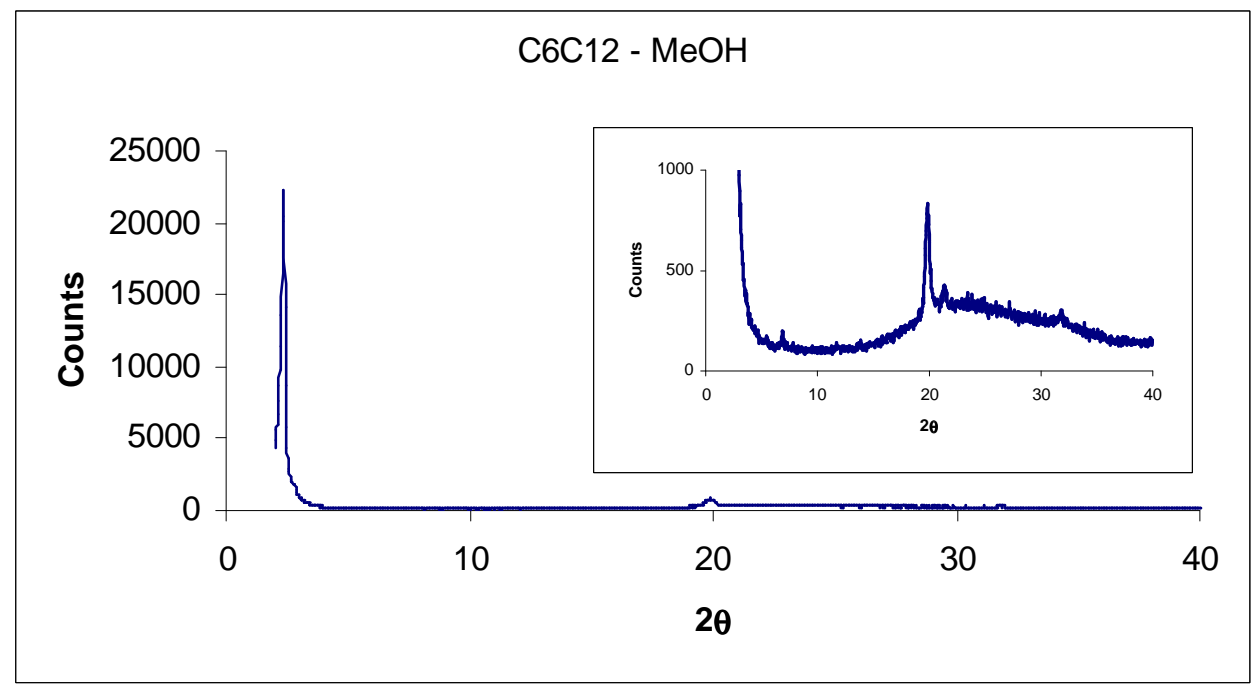



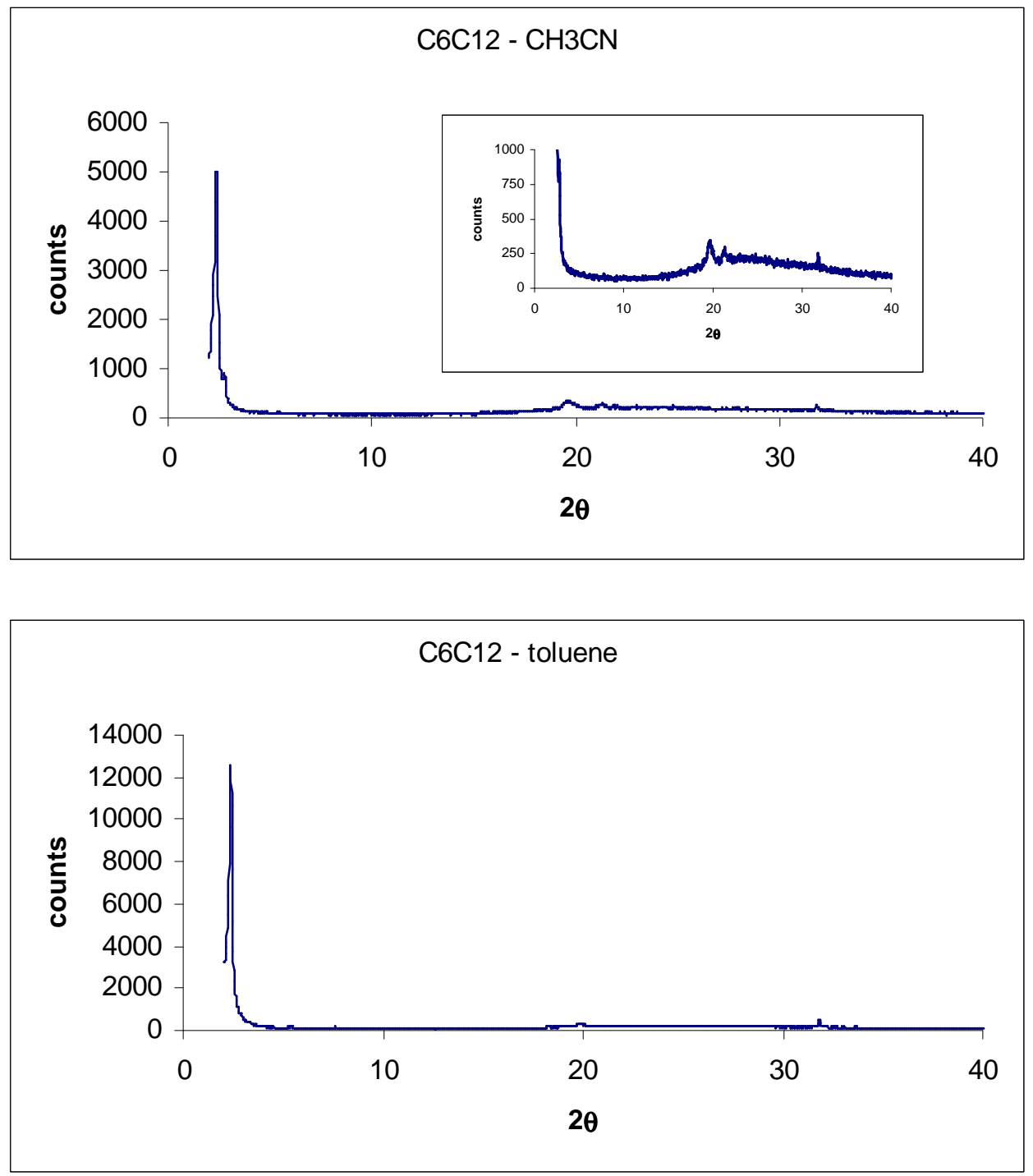

\section{Compound 10}

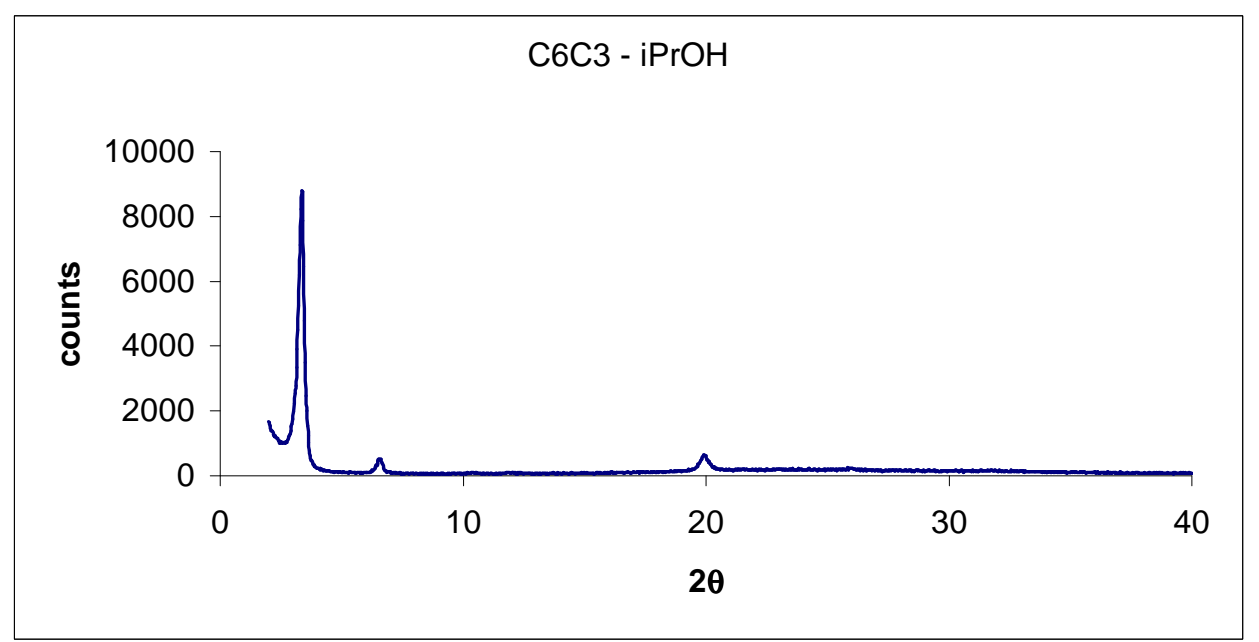



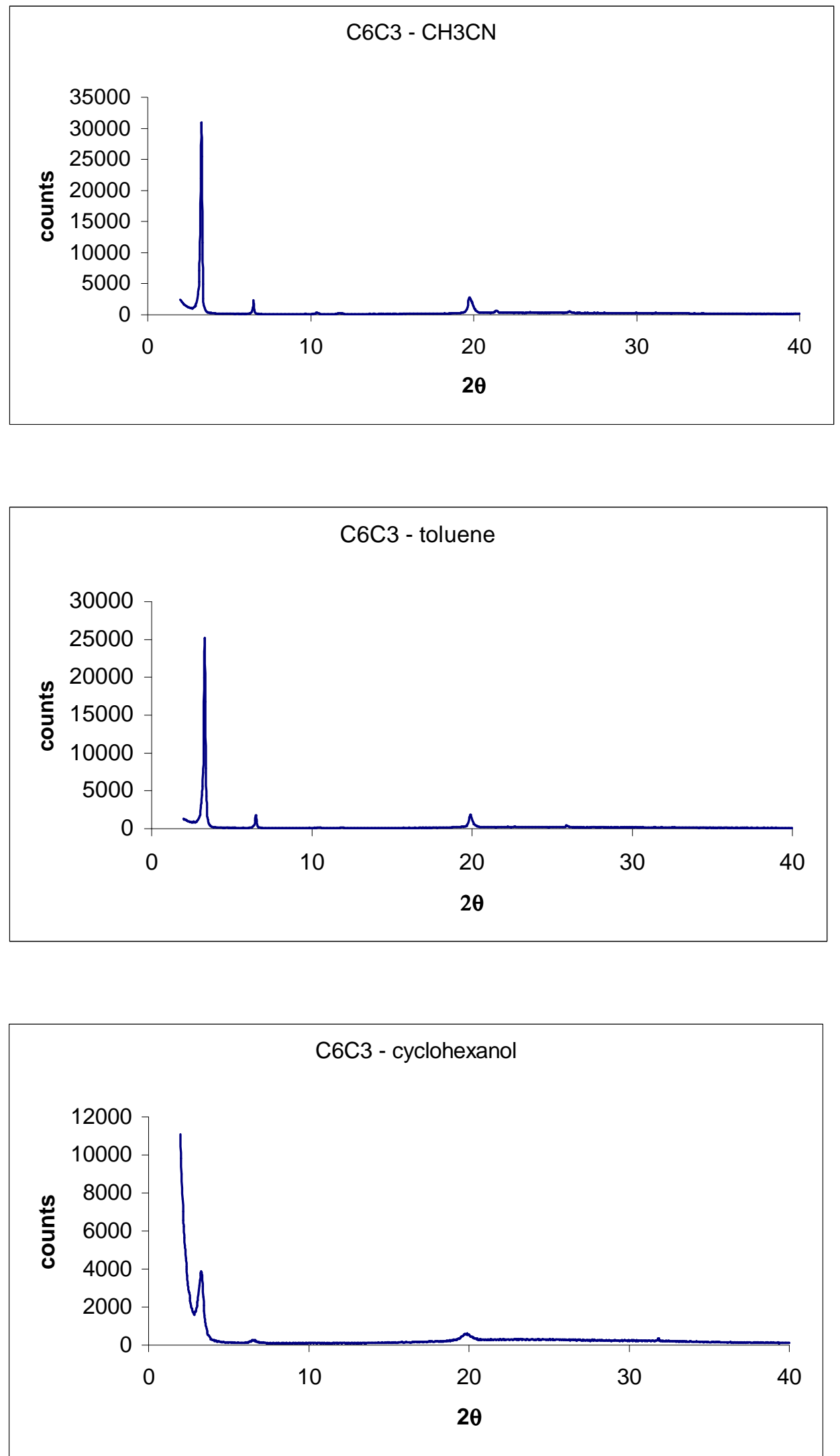


\section{Compound 11}
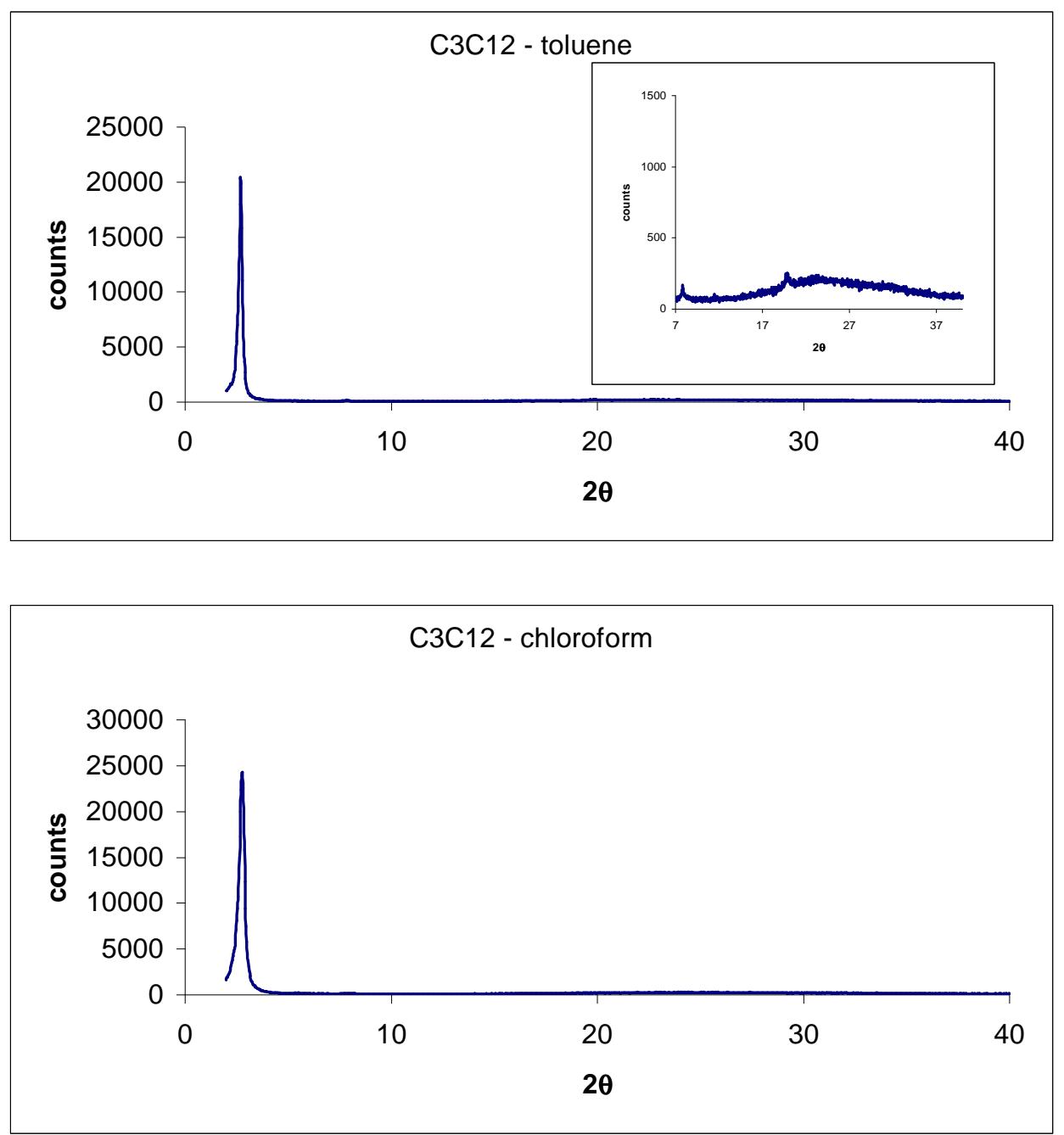

\section{Compound 12}

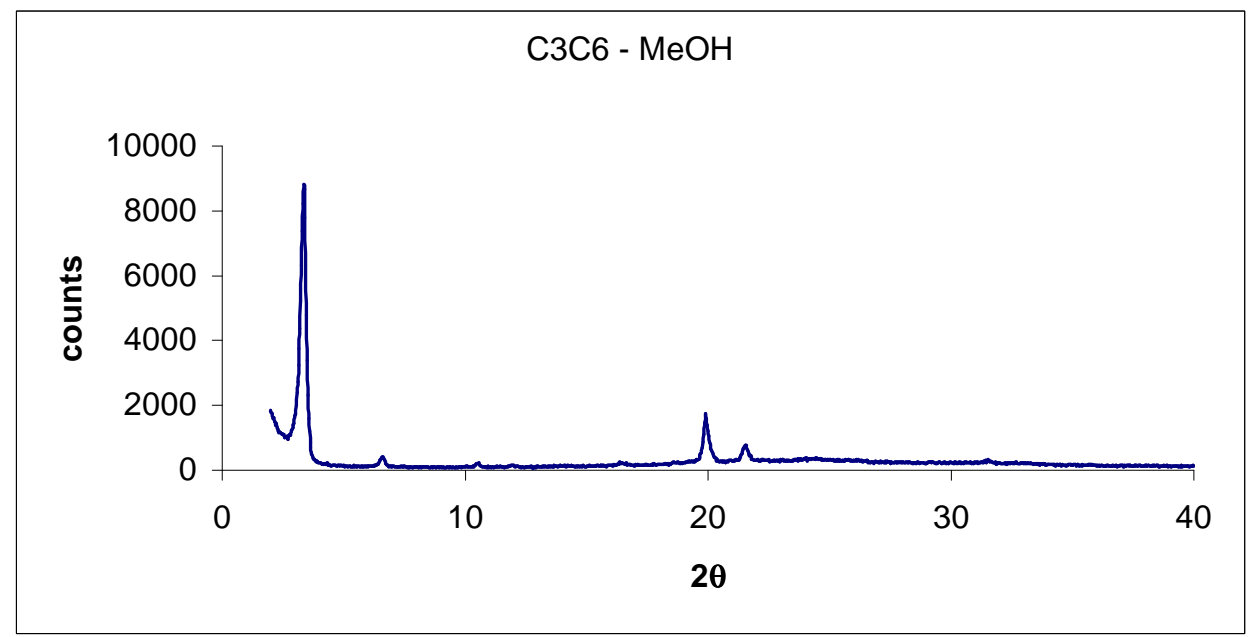



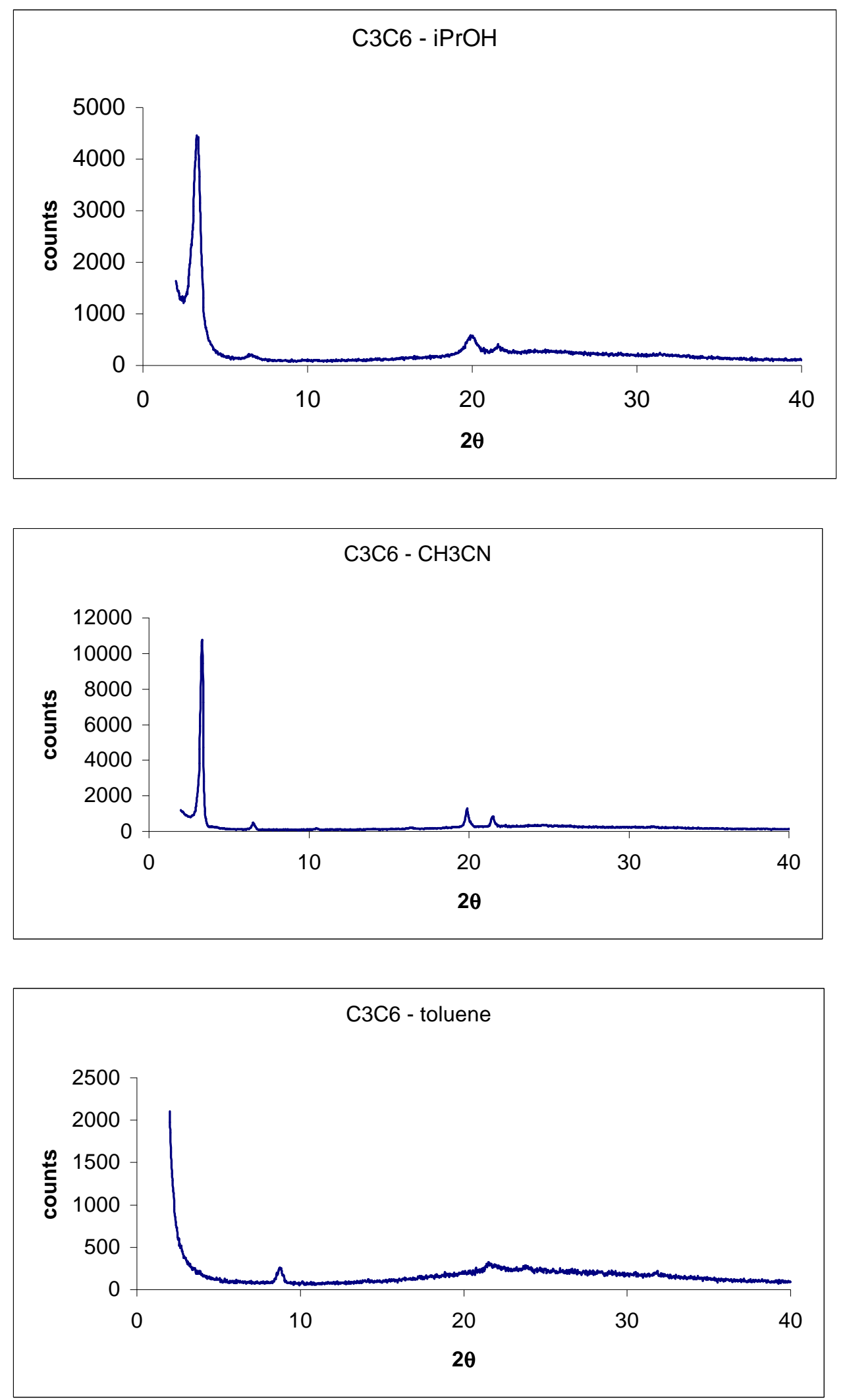


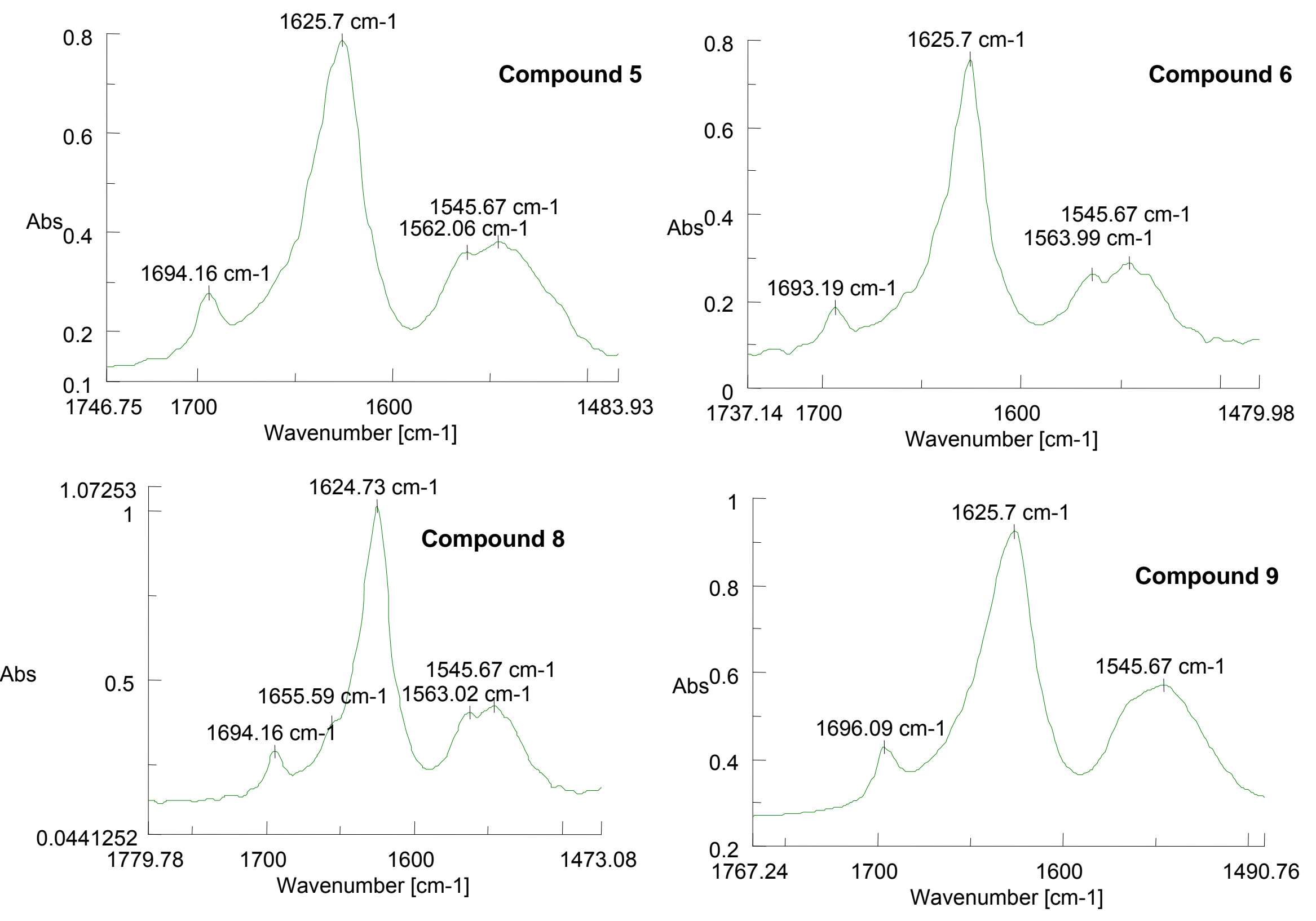



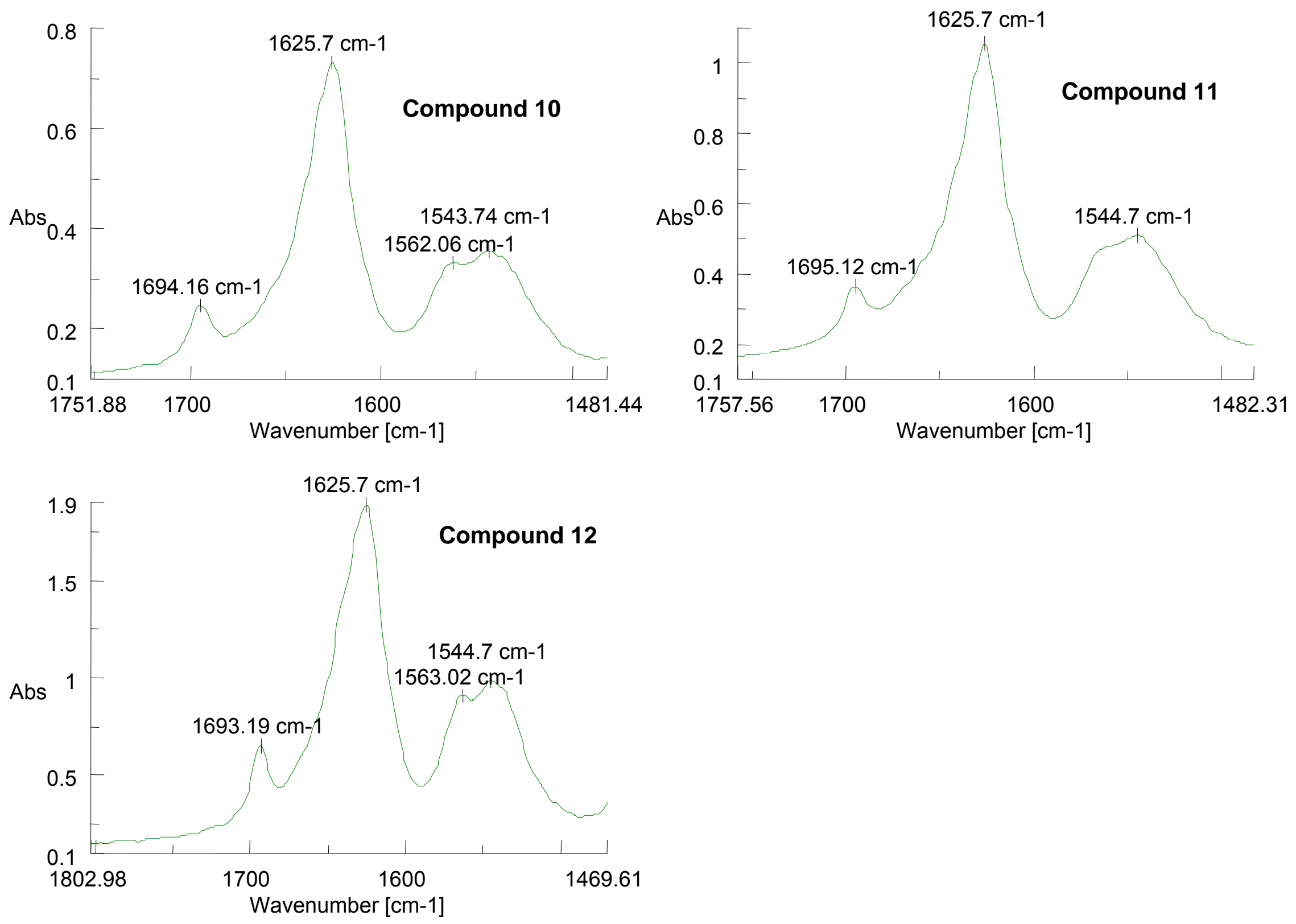


\section{Compound 15}

$1618.95 \mathrm{~cm}-1$
$1632.45 \mathrm{~cm}-1$
$1649.8 \mathrm{~cm}-1$
$1698.12 \mathrm{~cm}-1$
$168.98 \mathrm{~cm}-1$
Wavenumber [cm-1]

\section{Compound 17}

Wavenumber $[\mathrm{cm}-1]$

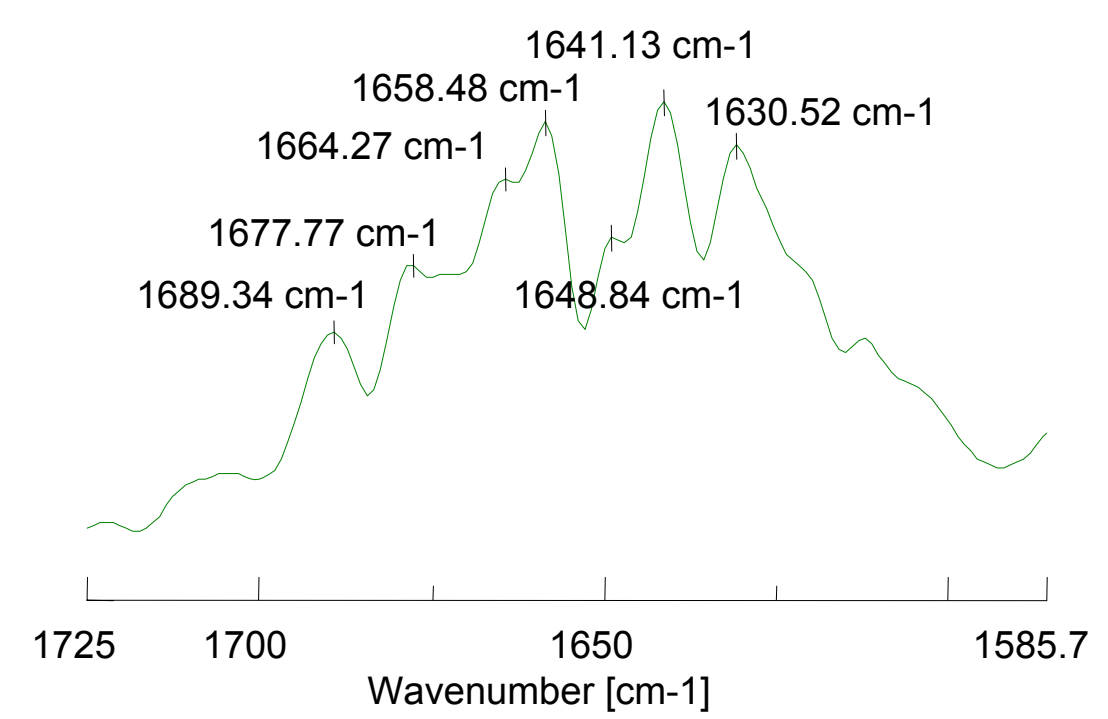


సิํำ

đi

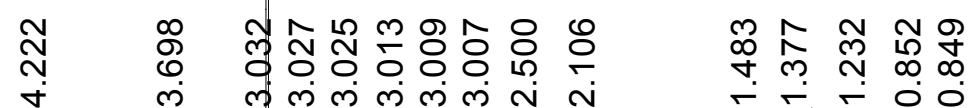
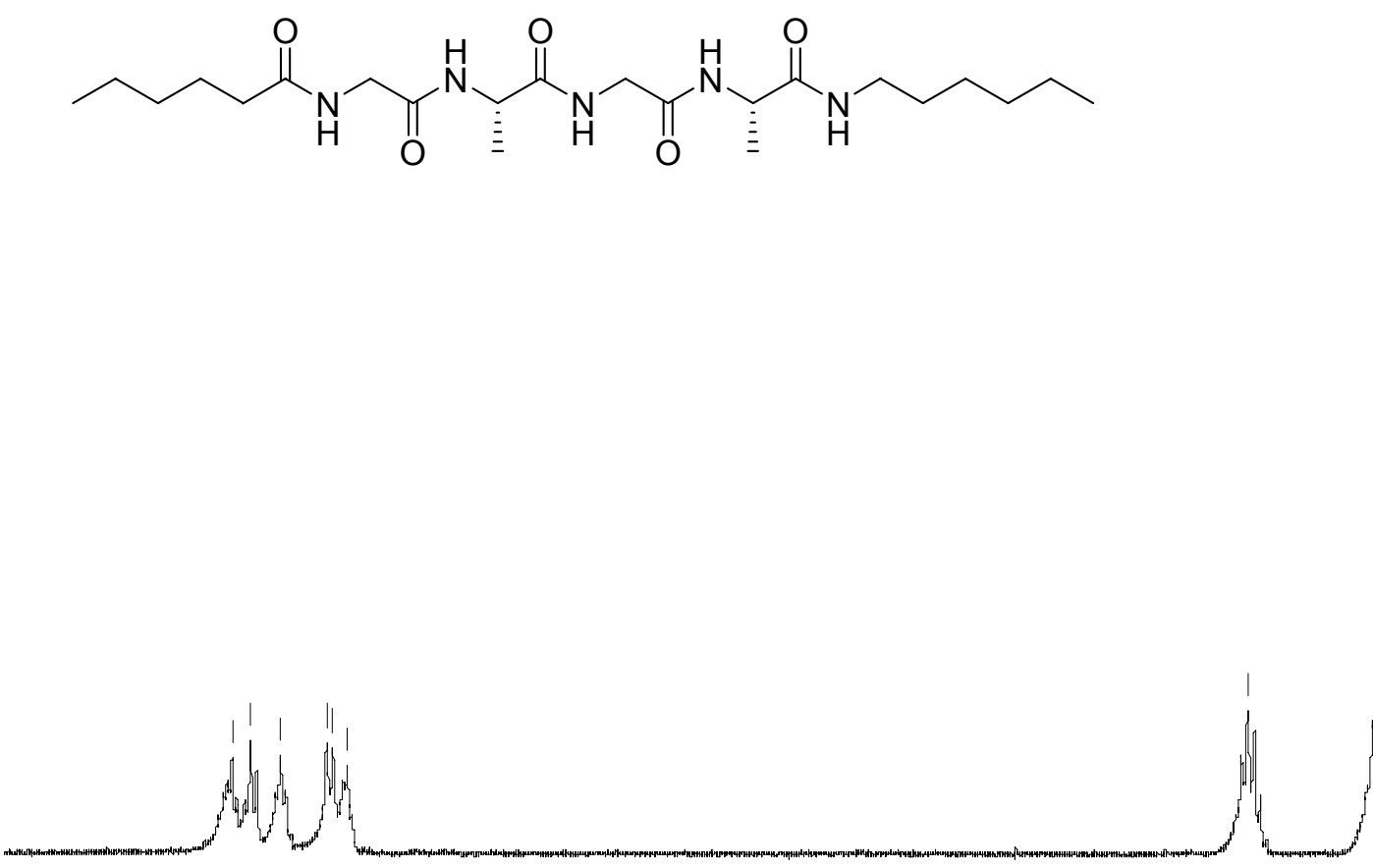

$$
\begin{aligned}
& \text { N } \\
& \stackrel{N}{N} \stackrel{N}{N}
\end{aligned}
$$
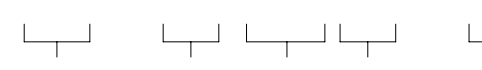

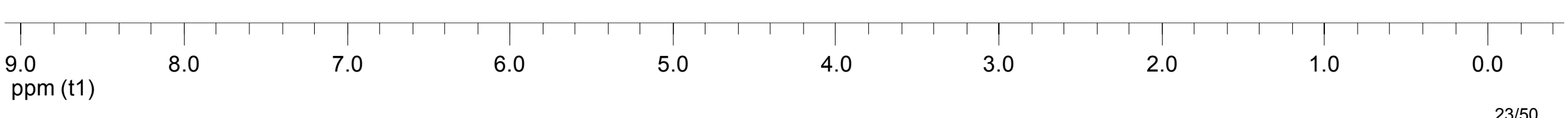


Escuder et al.

\section{Compound 5}

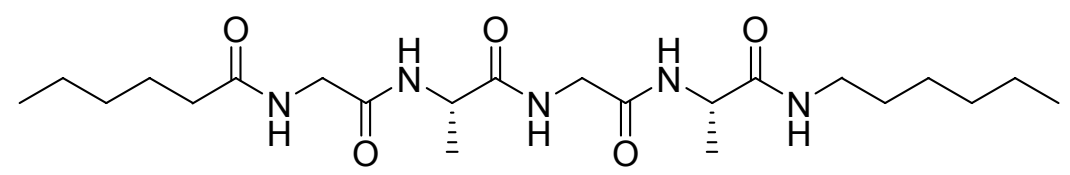

Biomimetic Self-assembly of Tetrapeptides into Fibrillar Networks...

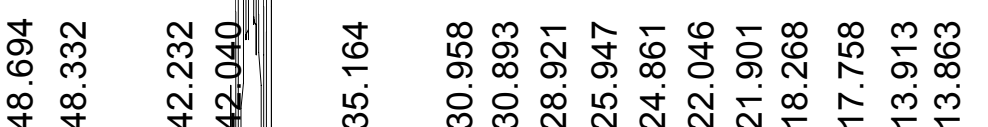

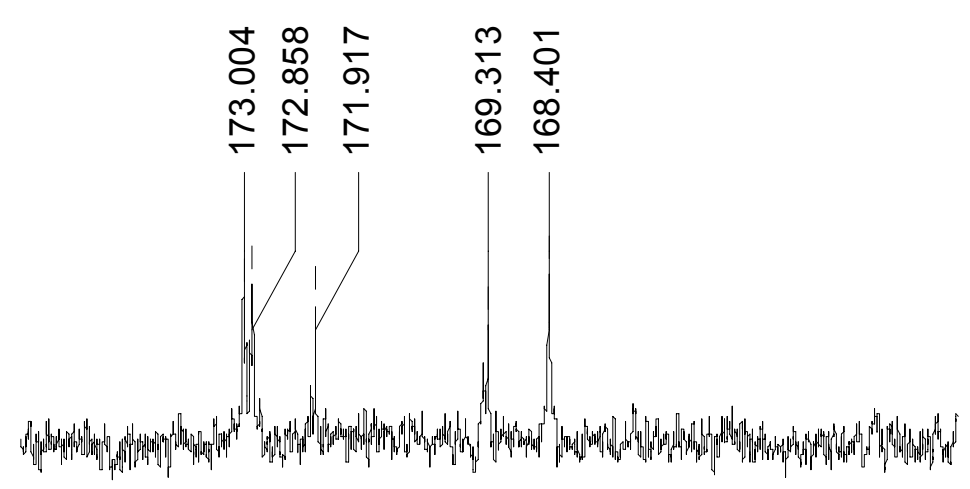


Escuder et al.

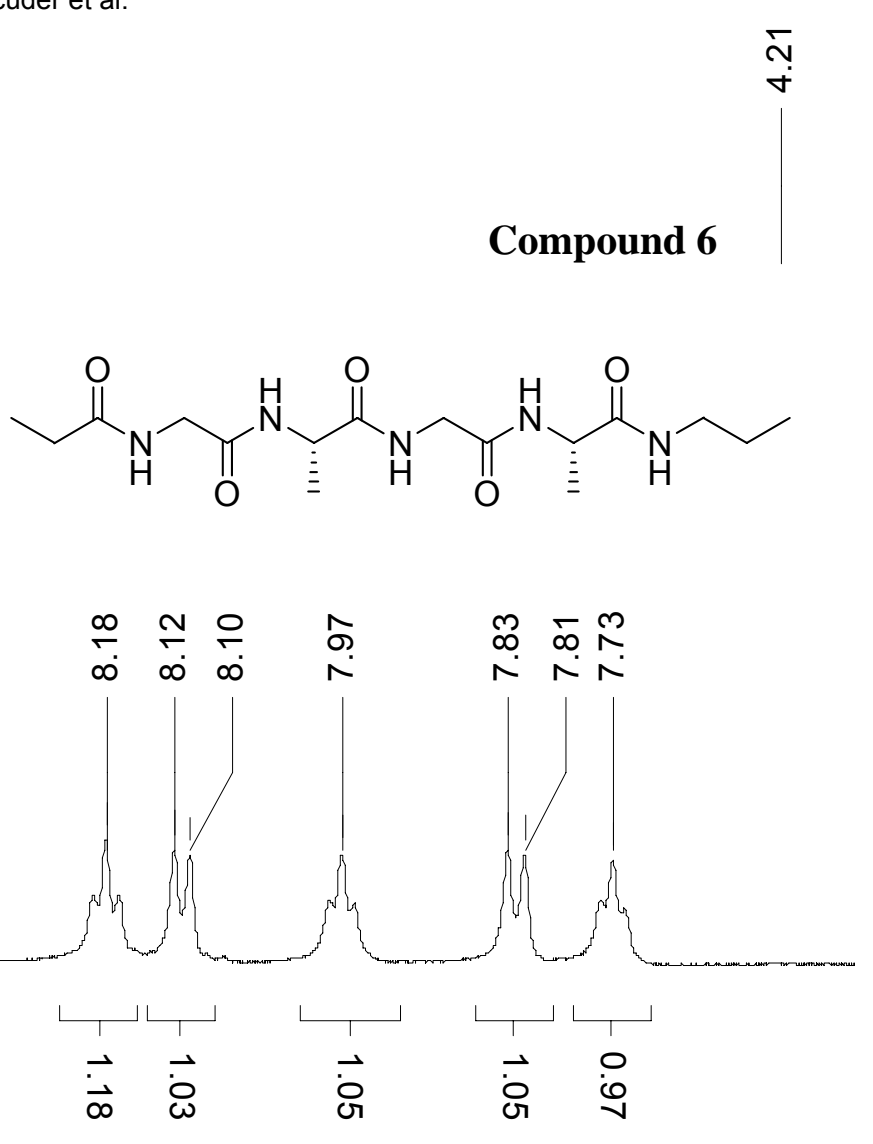

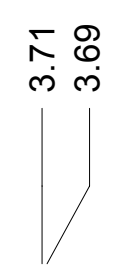

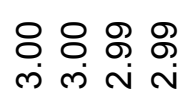

Biomimetic Self-assembly of Tetrapeptides into Fibrillar Networks...

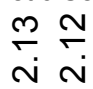

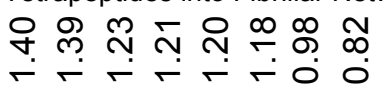

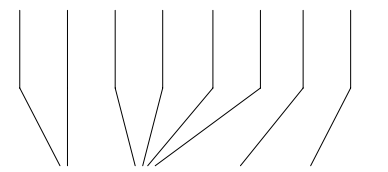

\section{(1)}
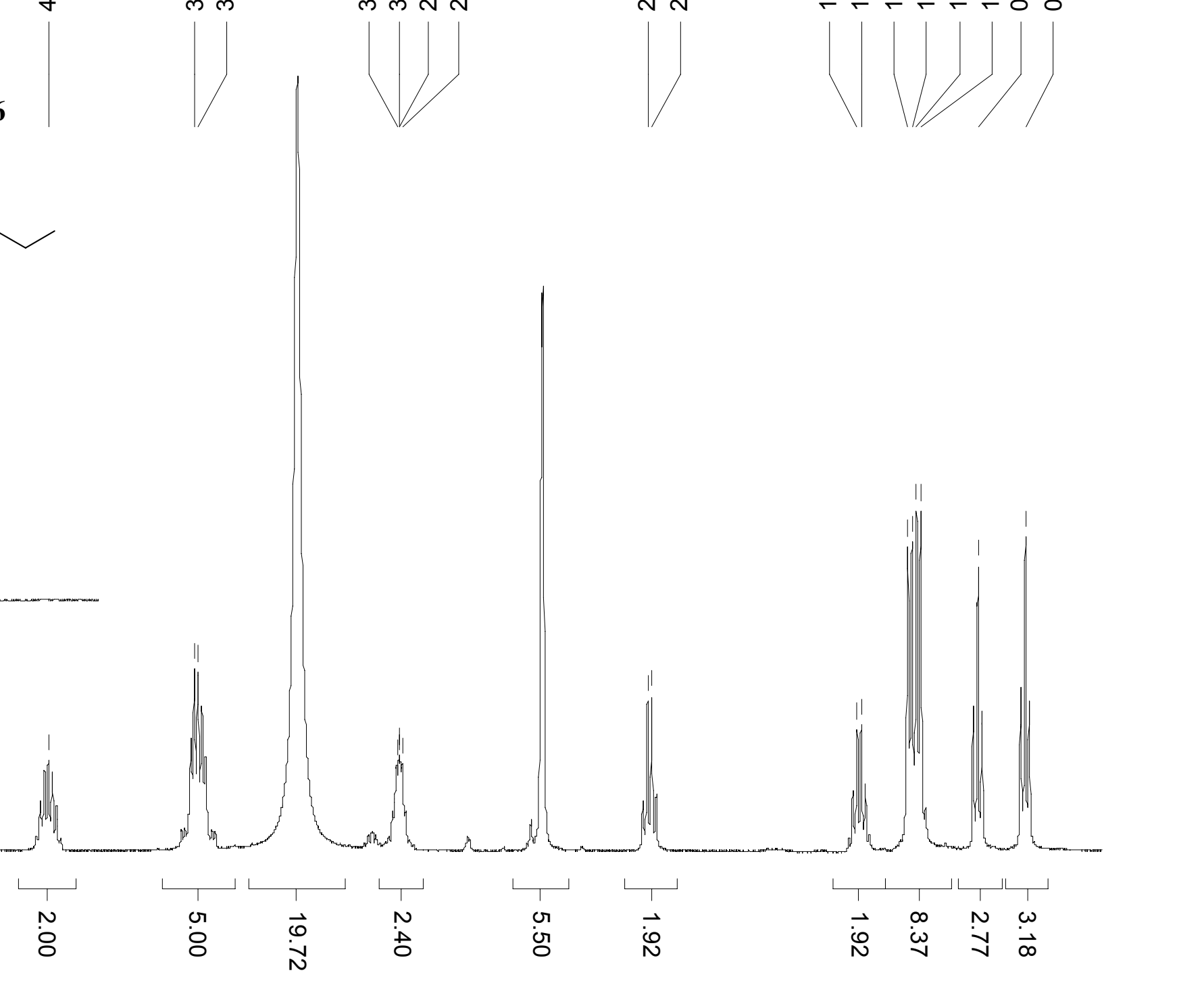

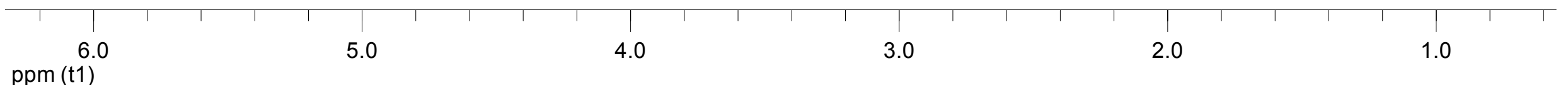


Escuder et al.

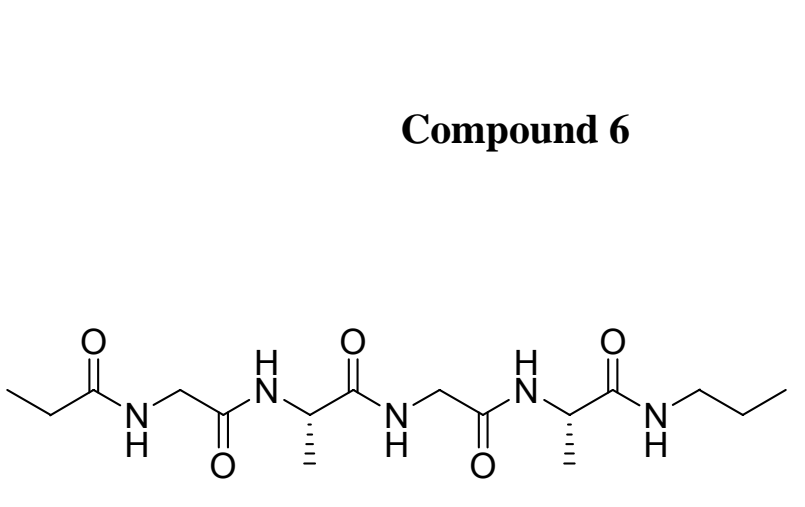

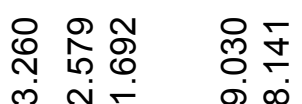

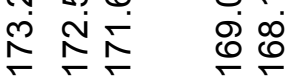

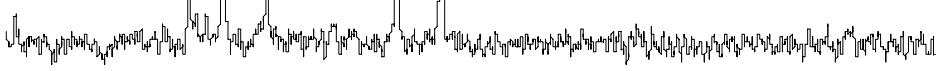

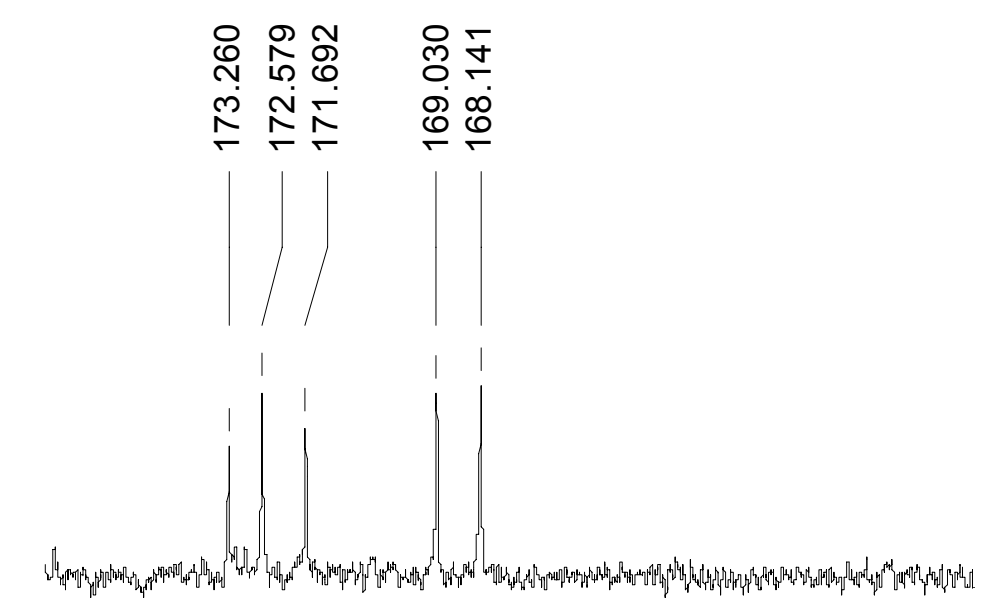

Biomimetic Self-assembly of Tetrapeptides into Fibrillar Networks...

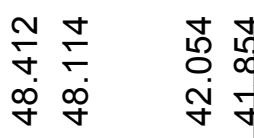
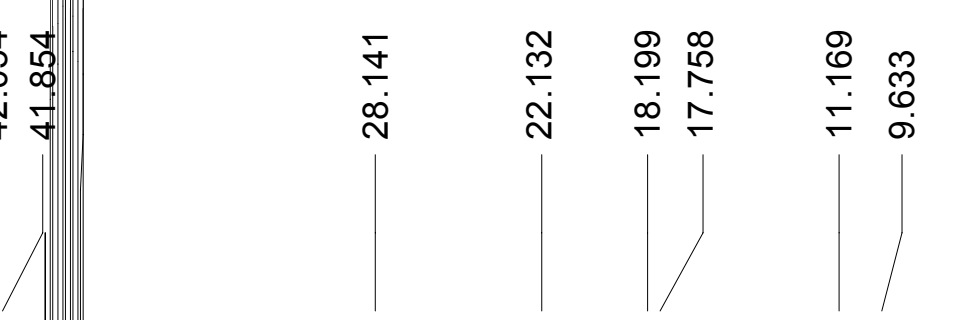

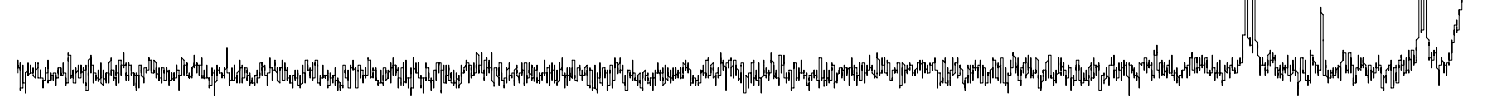

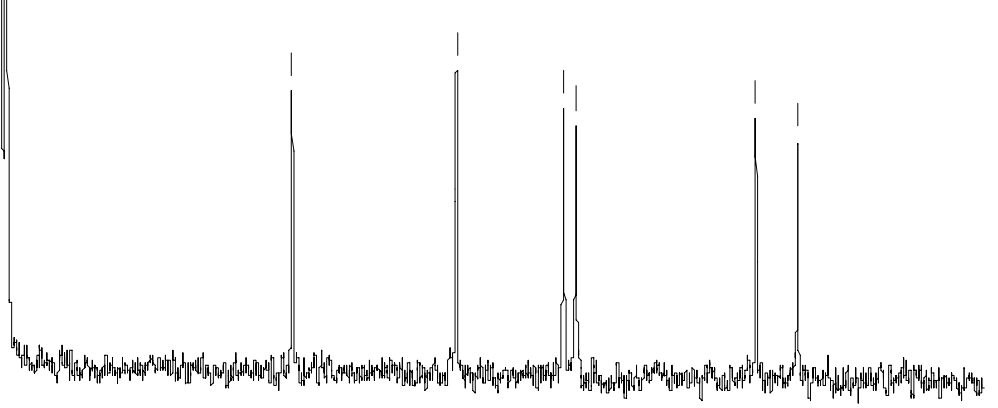


Escuder et al.

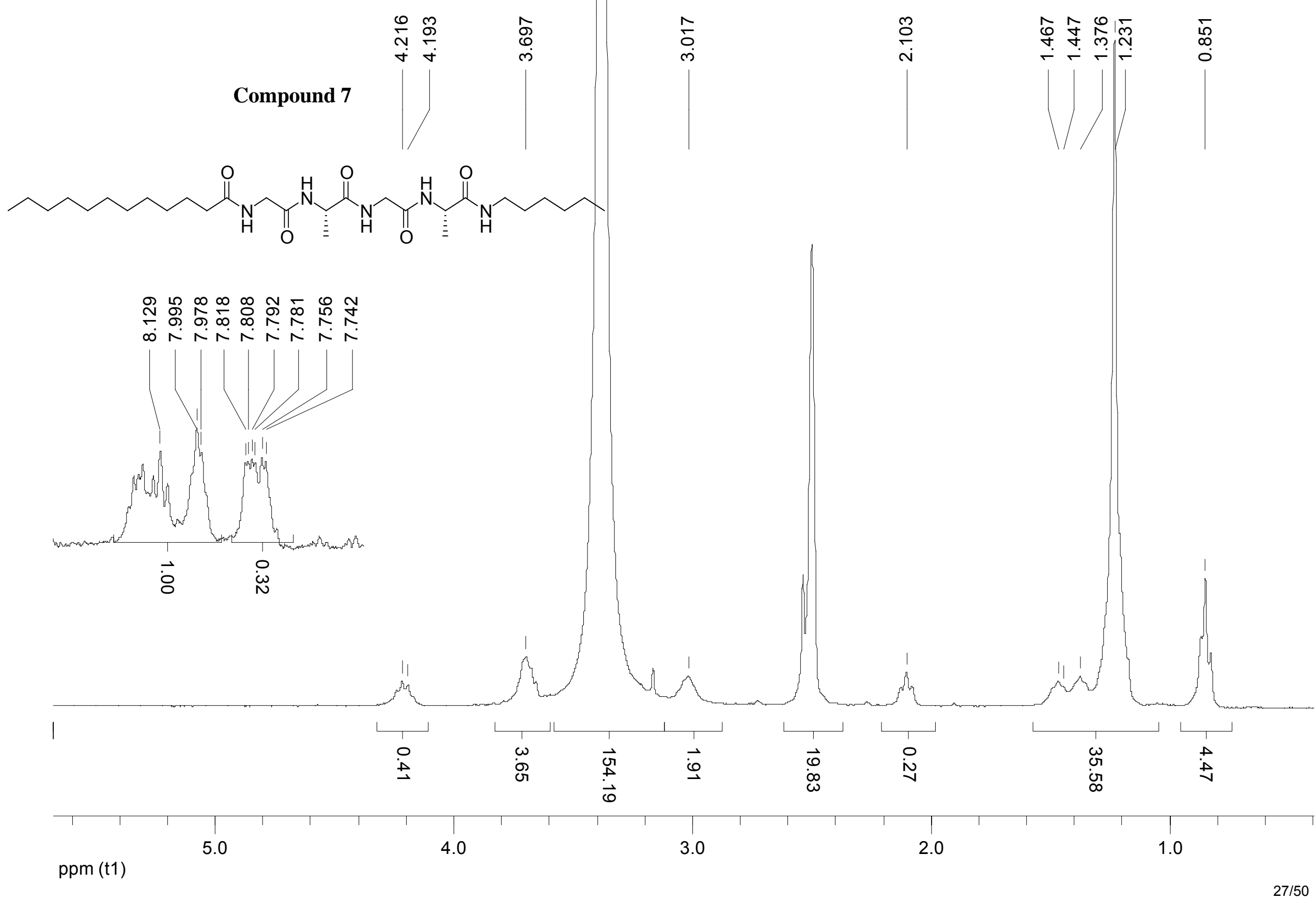


。

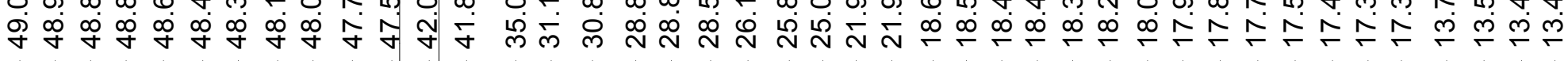

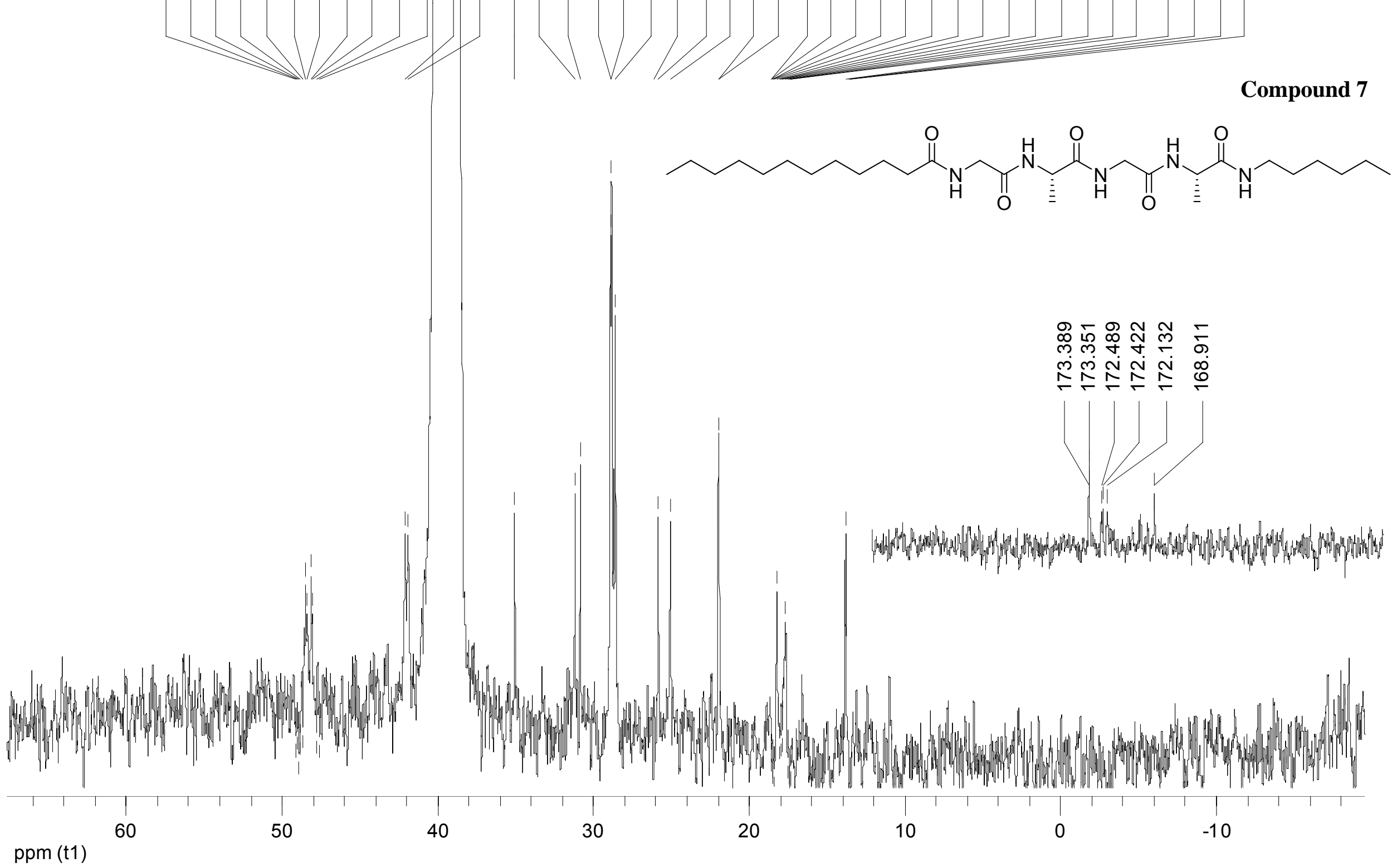


Escuder et al.

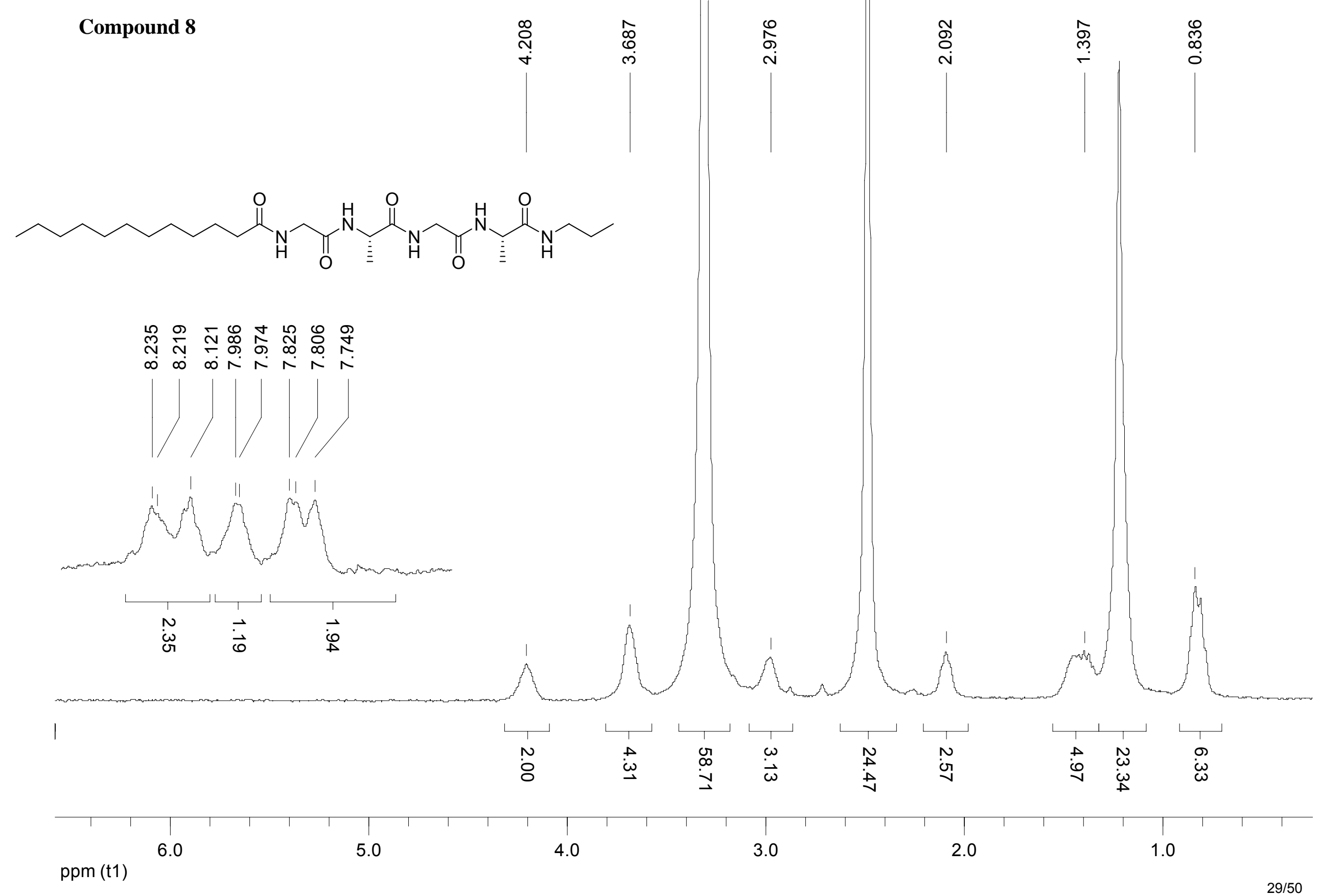




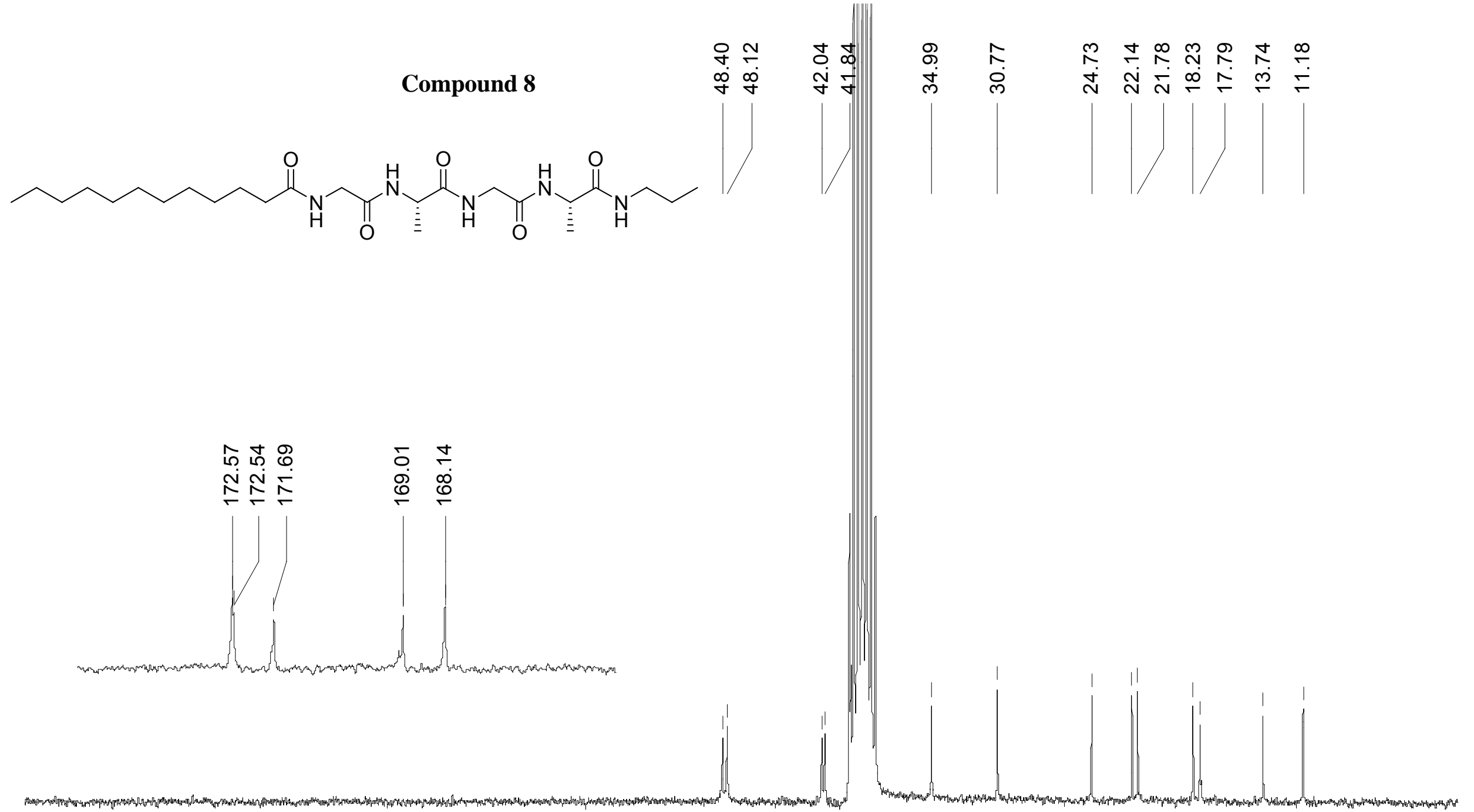

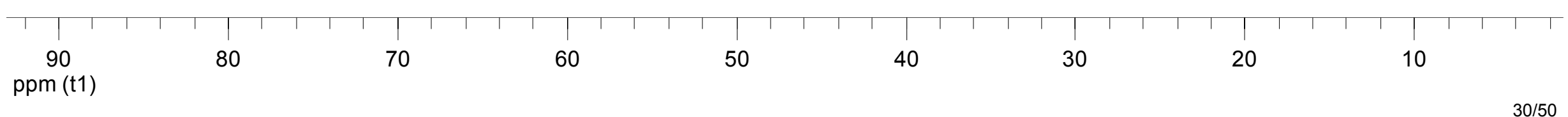


Escuder et al.

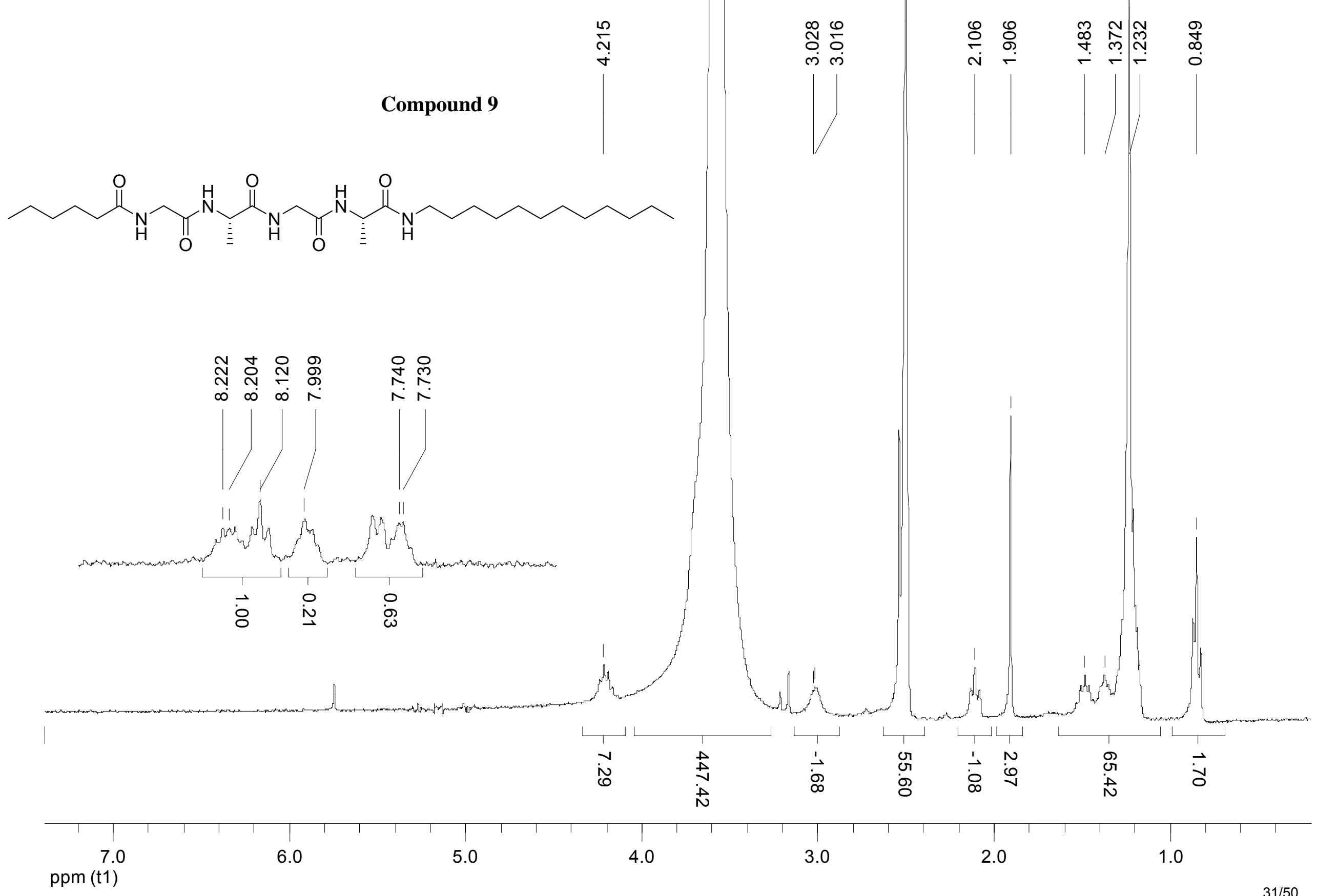


Escuder et al.

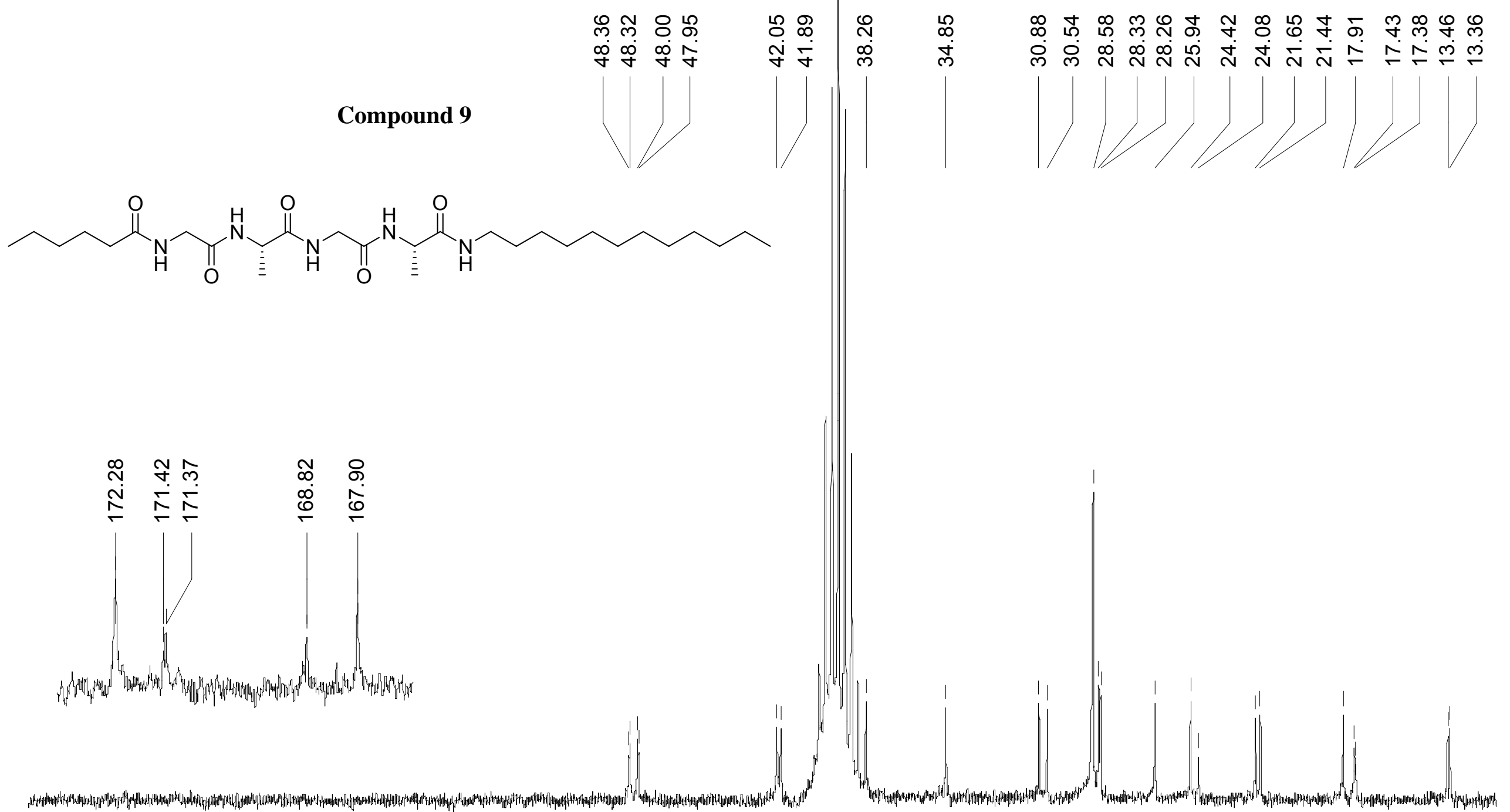

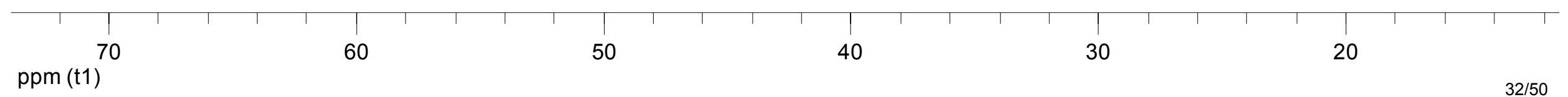




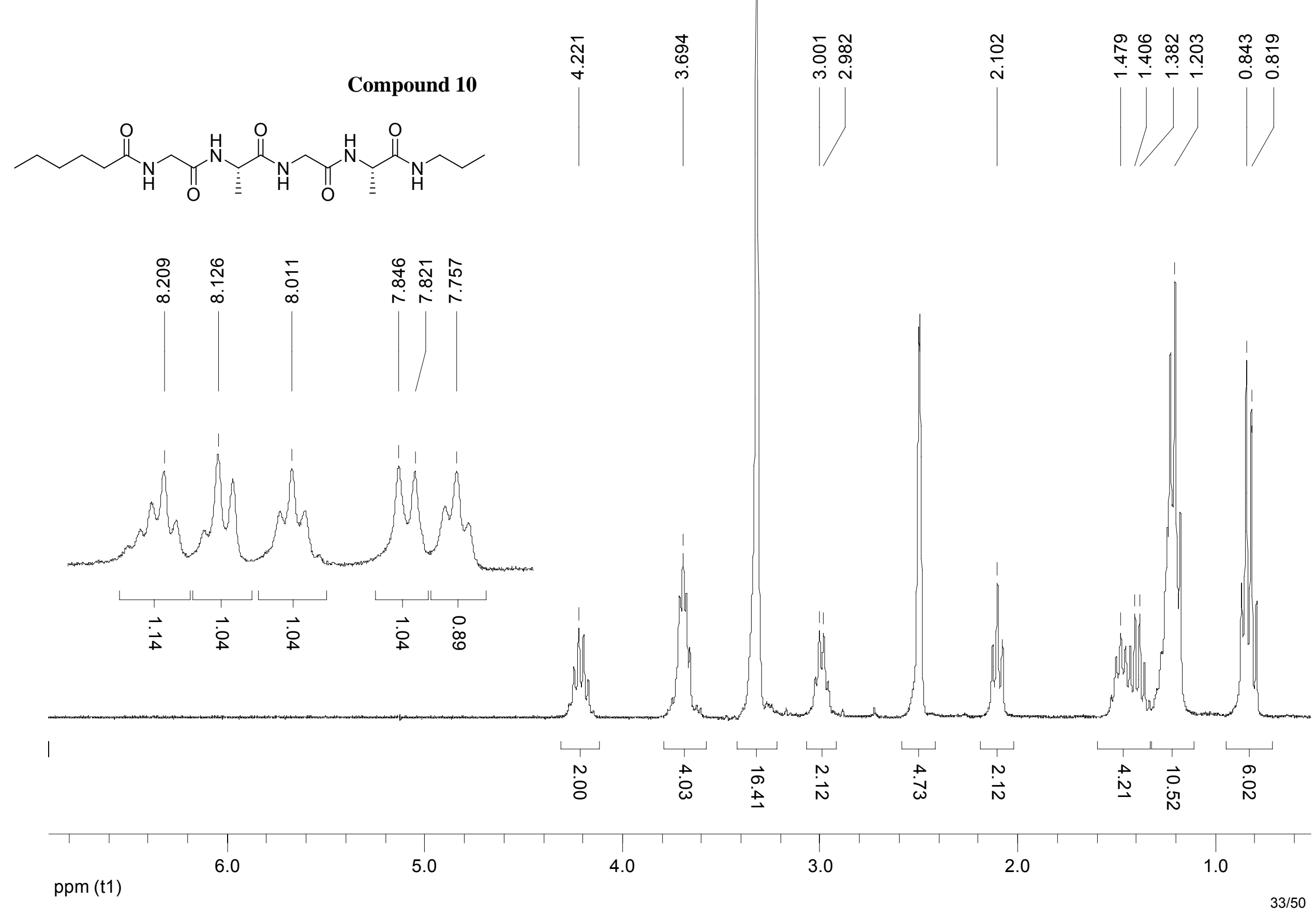


Escuder et al.

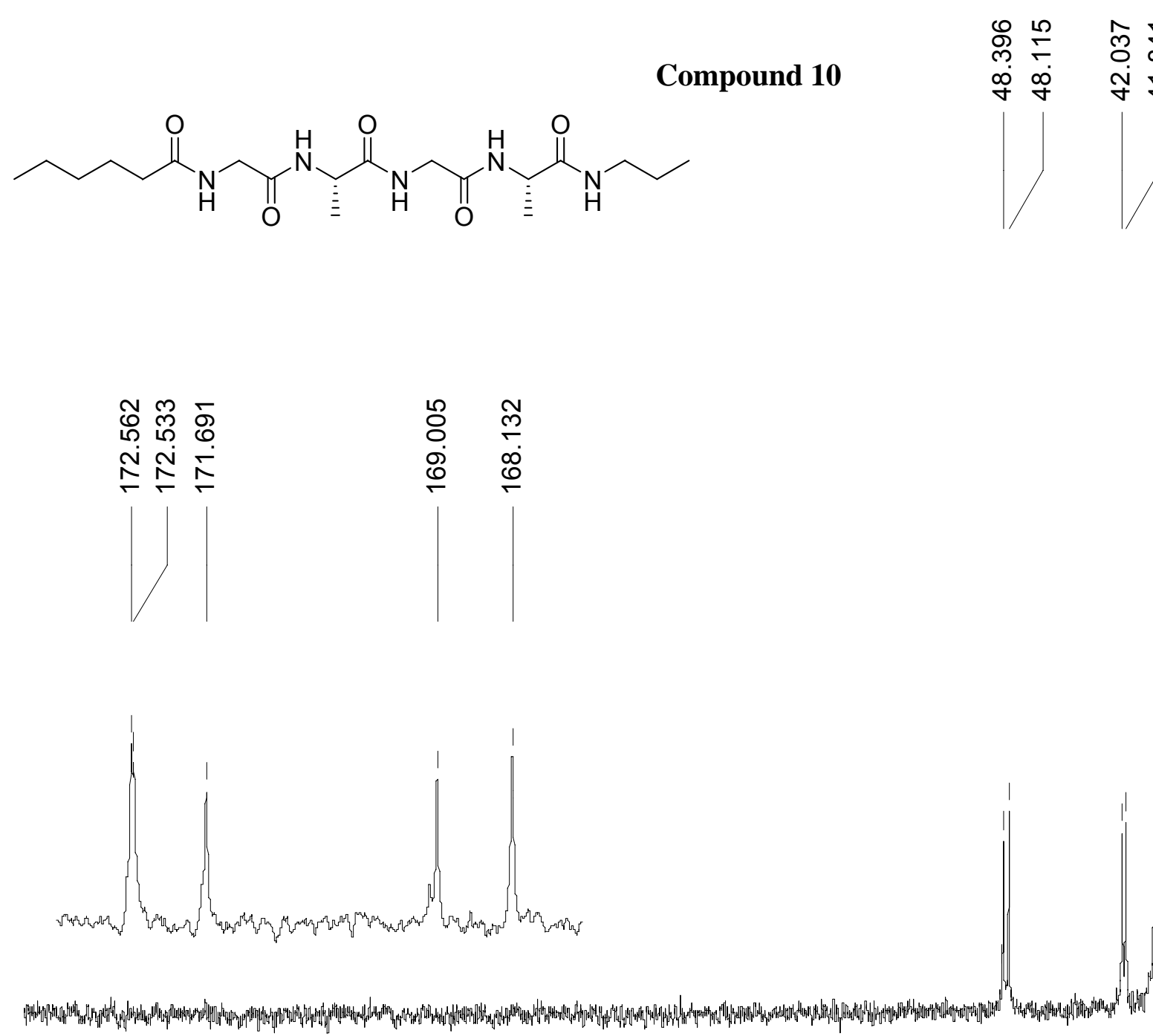

Biomimetic Self-assembly of Tetrapeptides into Fibrillar Networks...

\begin{tabular}{|c|c|c|c|c|c|c|c|c|c|}
\hline 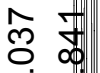 & ๙ু & $\stackrel{0}{N}$ & $\stackrel{m}{N}$ & $\underset{\Xi}{\check{\Xi}}$ & $\hat{\hat{N}}$ & $\hat{N}$ & ঠ & 文 & $\stackrel{m}{\infty}$ \\
\hline$\underset{f}{\sim} \underset{f}{ }$ & ले & คి & $\stackrel{ \pm}{N}$ & N & $\bar{N}$ & $\stackrel{\infty}{\leftarrow}$ & $\Sigma$ & $m$ & \\
\hline
\end{tabular}

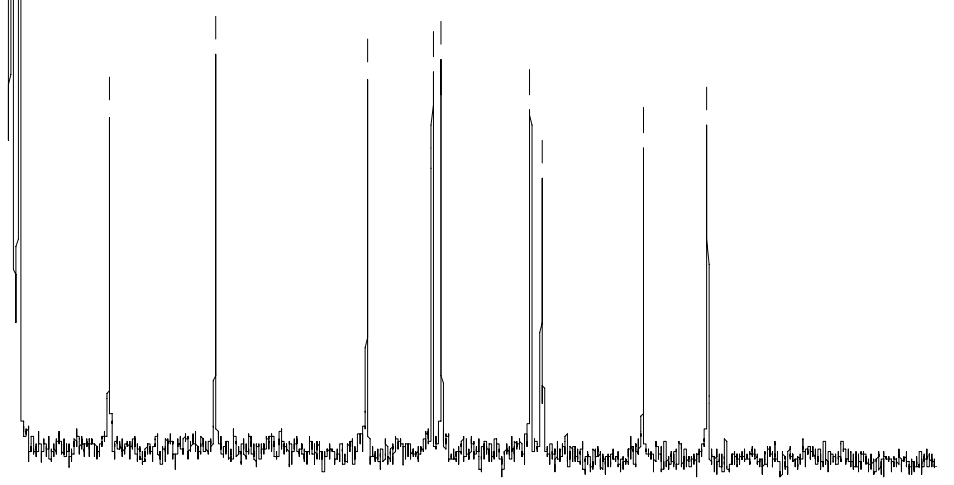




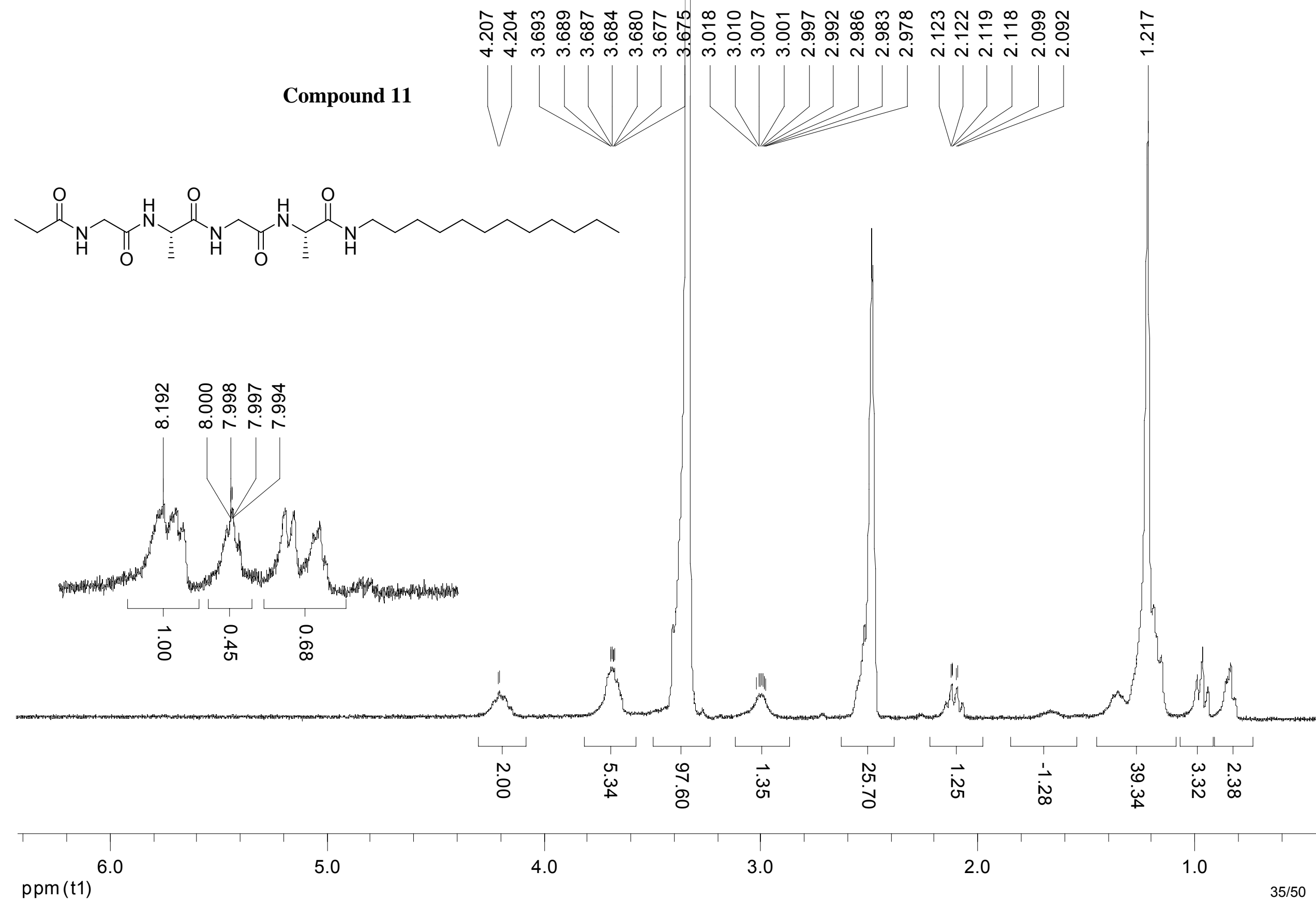




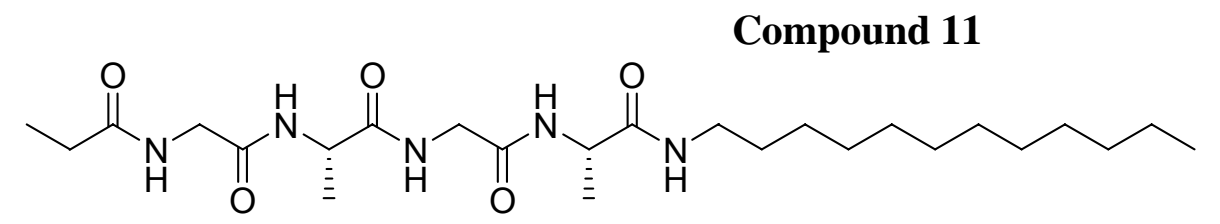

鹤 字 字

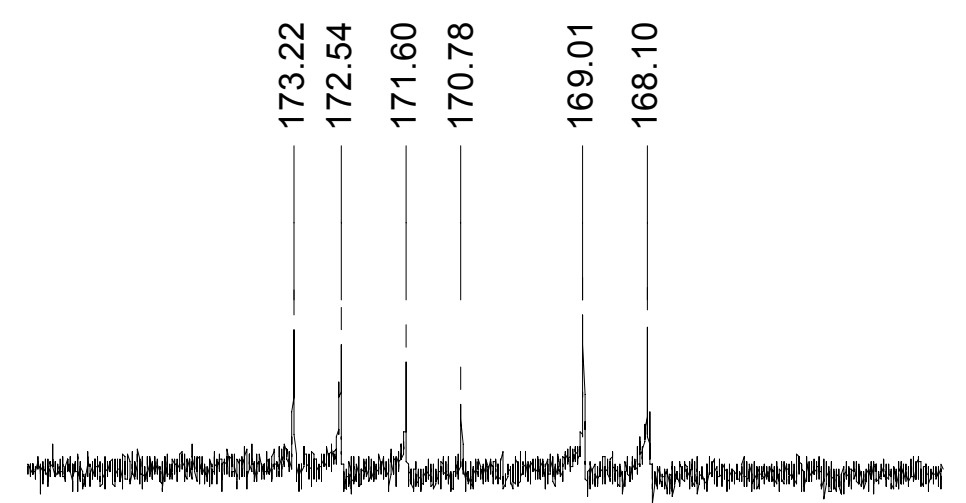




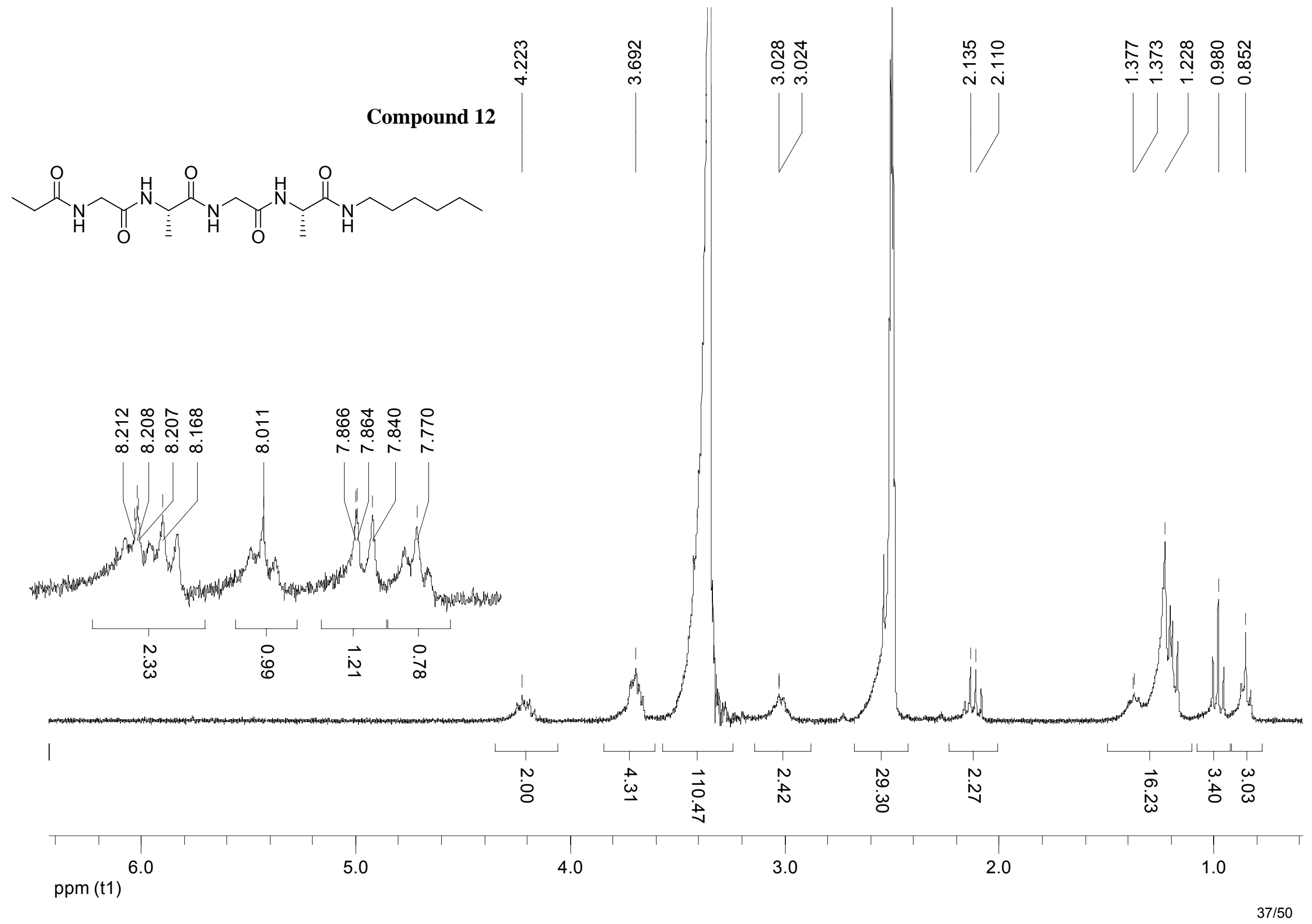


Escuder et al.

\section{Compound 12}

$\|_{O}^{O} \overbrace{\equiv}^{O}$

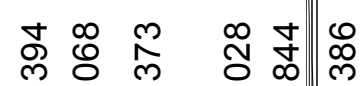

乎

Biomimetic Self-assembly of Tetrapeptides into Fibrillar Networks...

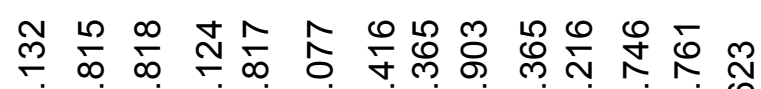
๙ি

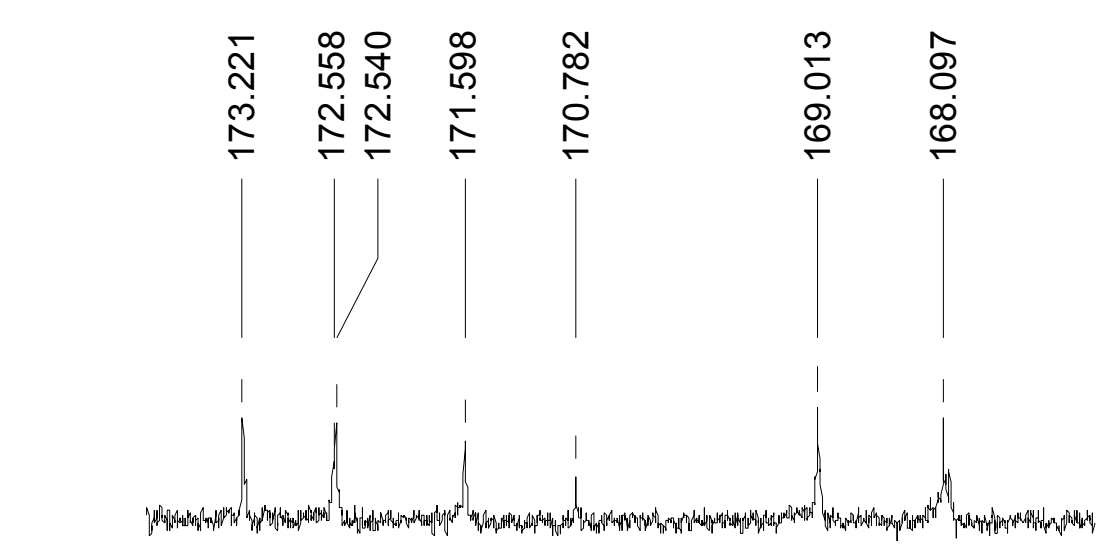

Pow 


\section{Compound 13}

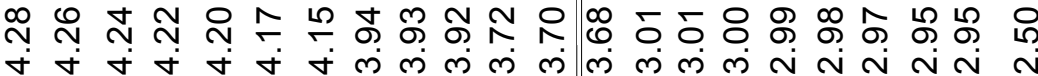

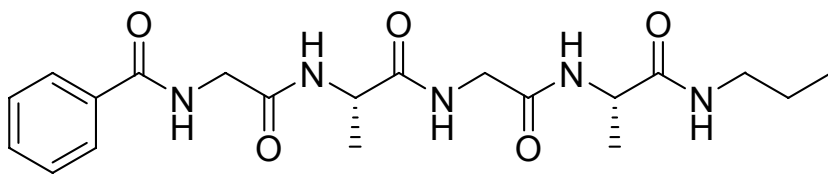

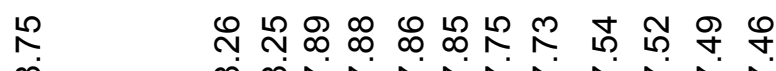
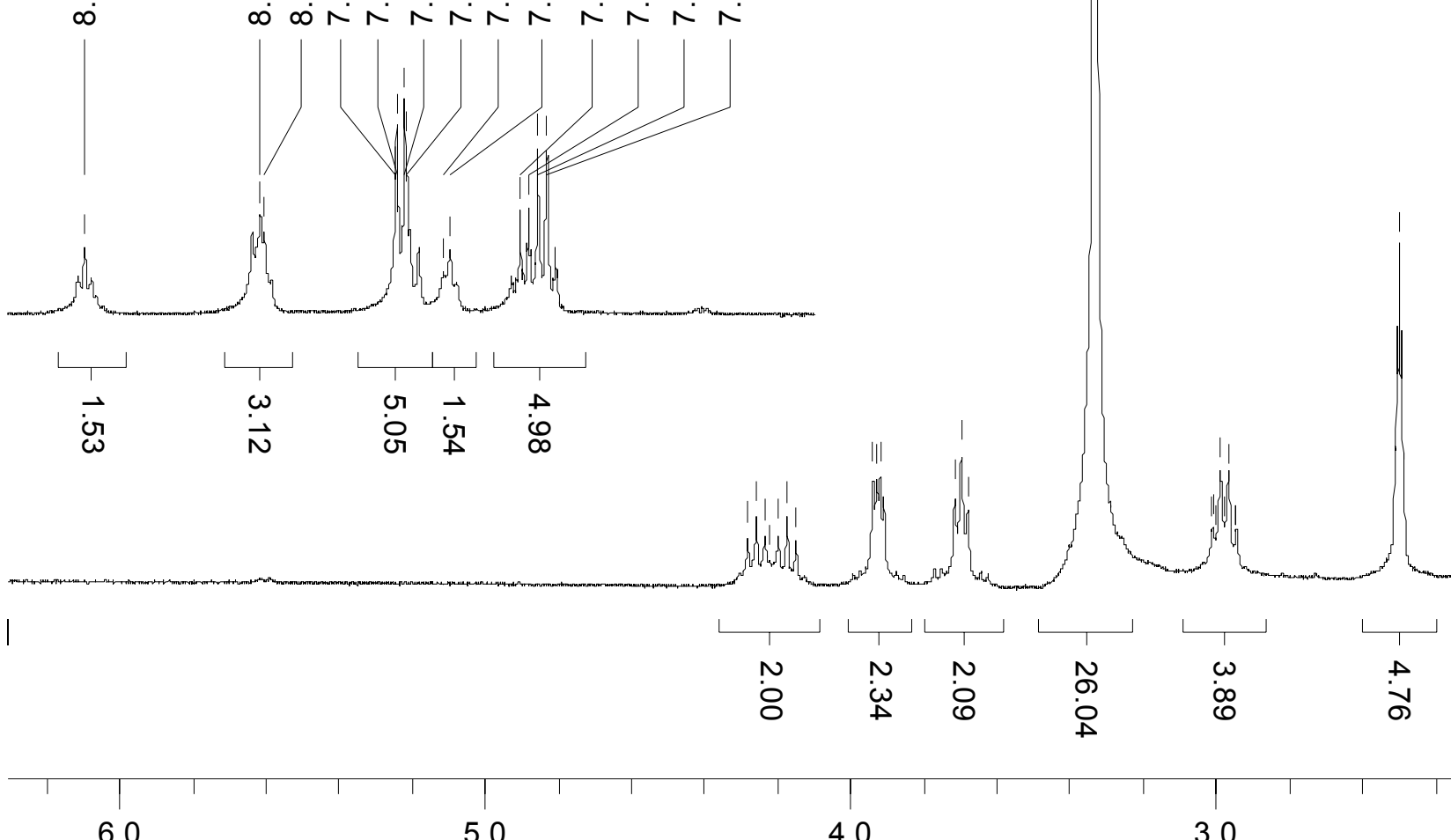
Escuder et al.

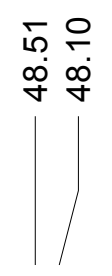

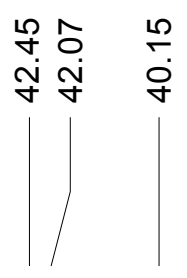

\&
Compound 13

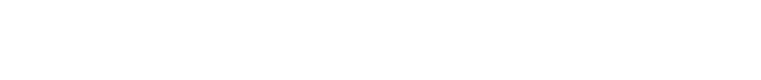

Biomimetic Self-assembly of Tetrapeptides into Fibrillar Networks...
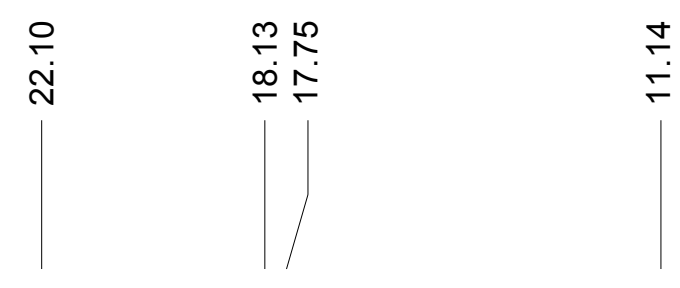
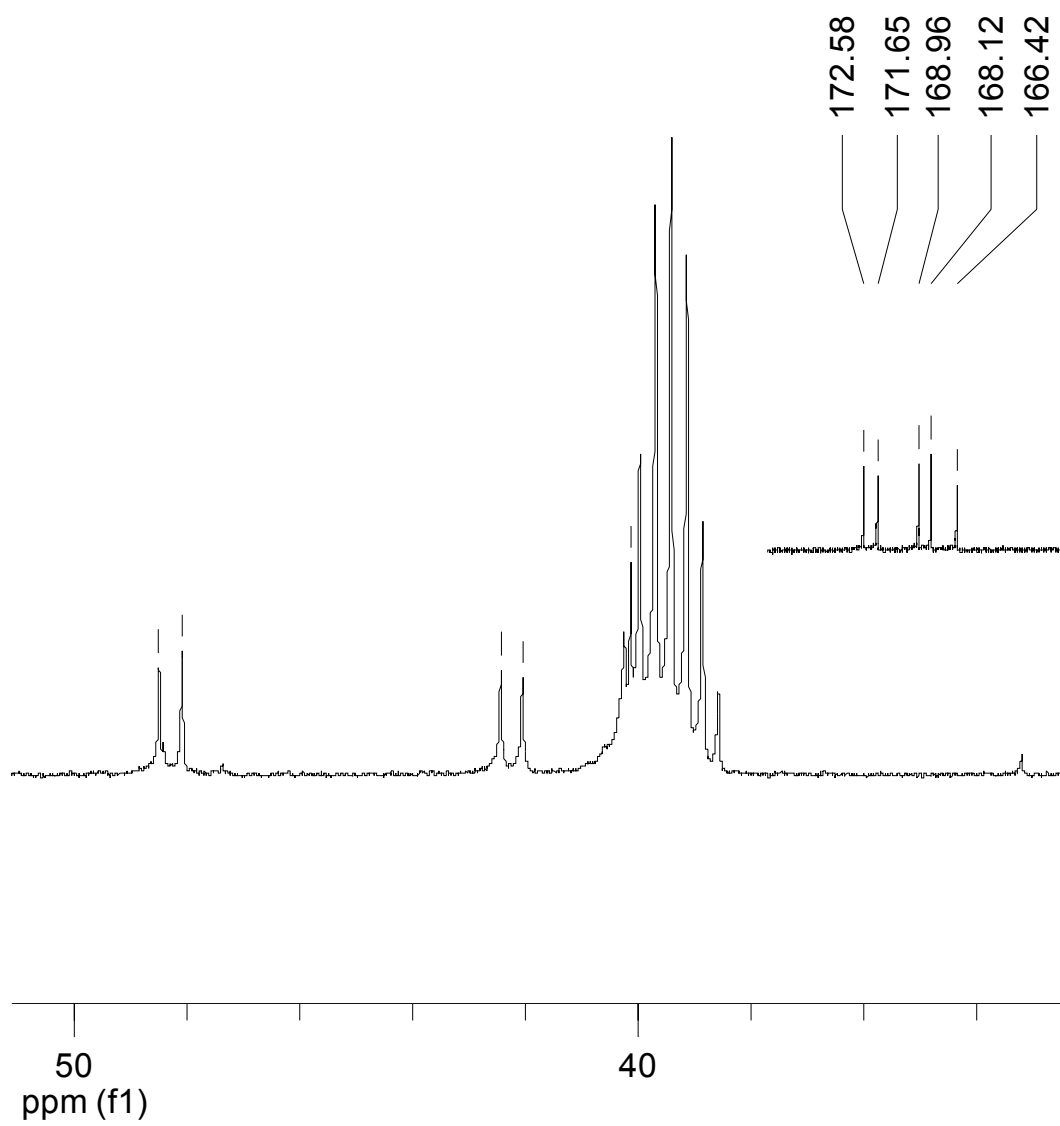

40

20

10

$40 / 50$ 


\section{Compound 14}

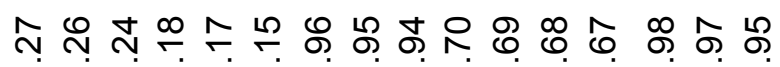

+

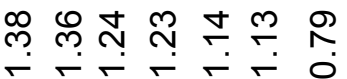

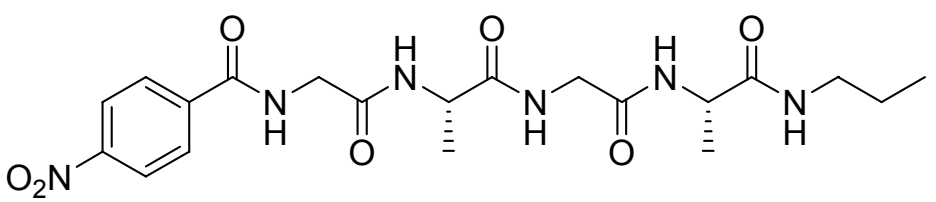

요용

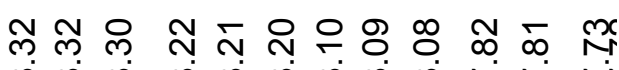

बの ब

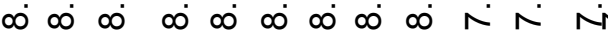
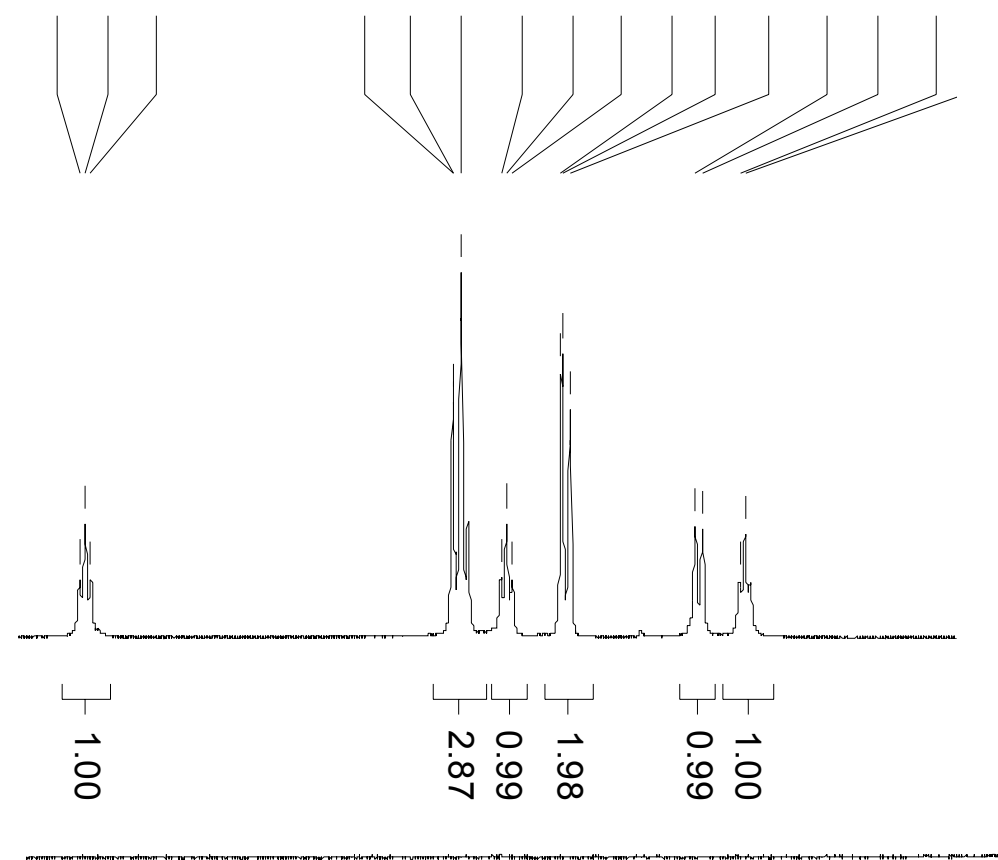

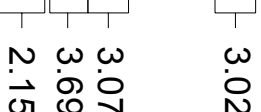




\section{Compound 14}

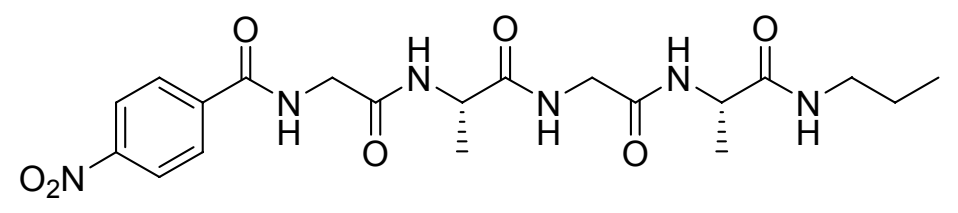

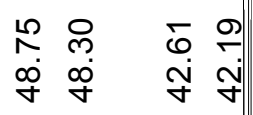

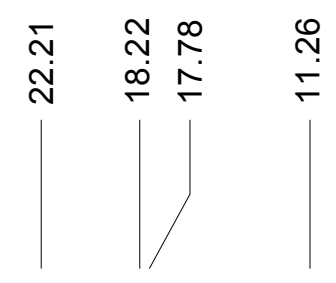

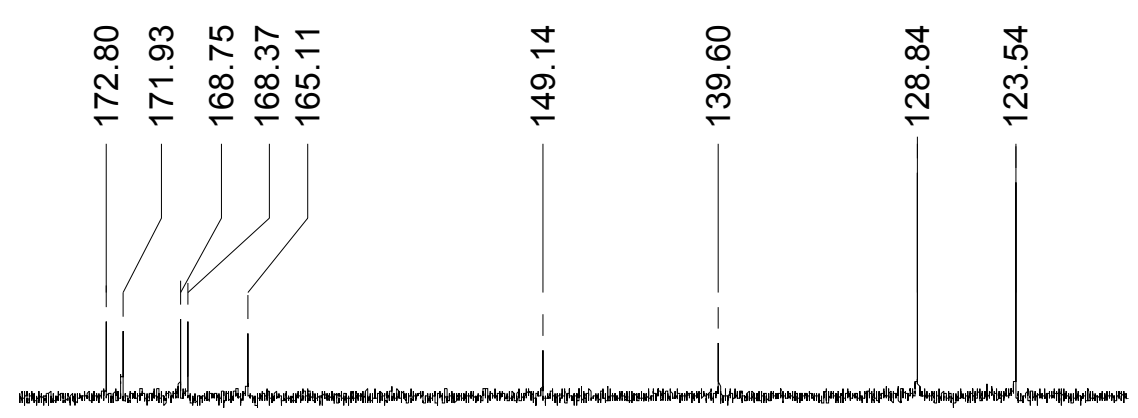

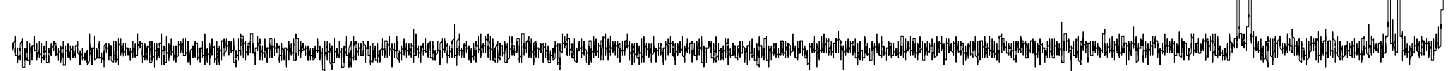




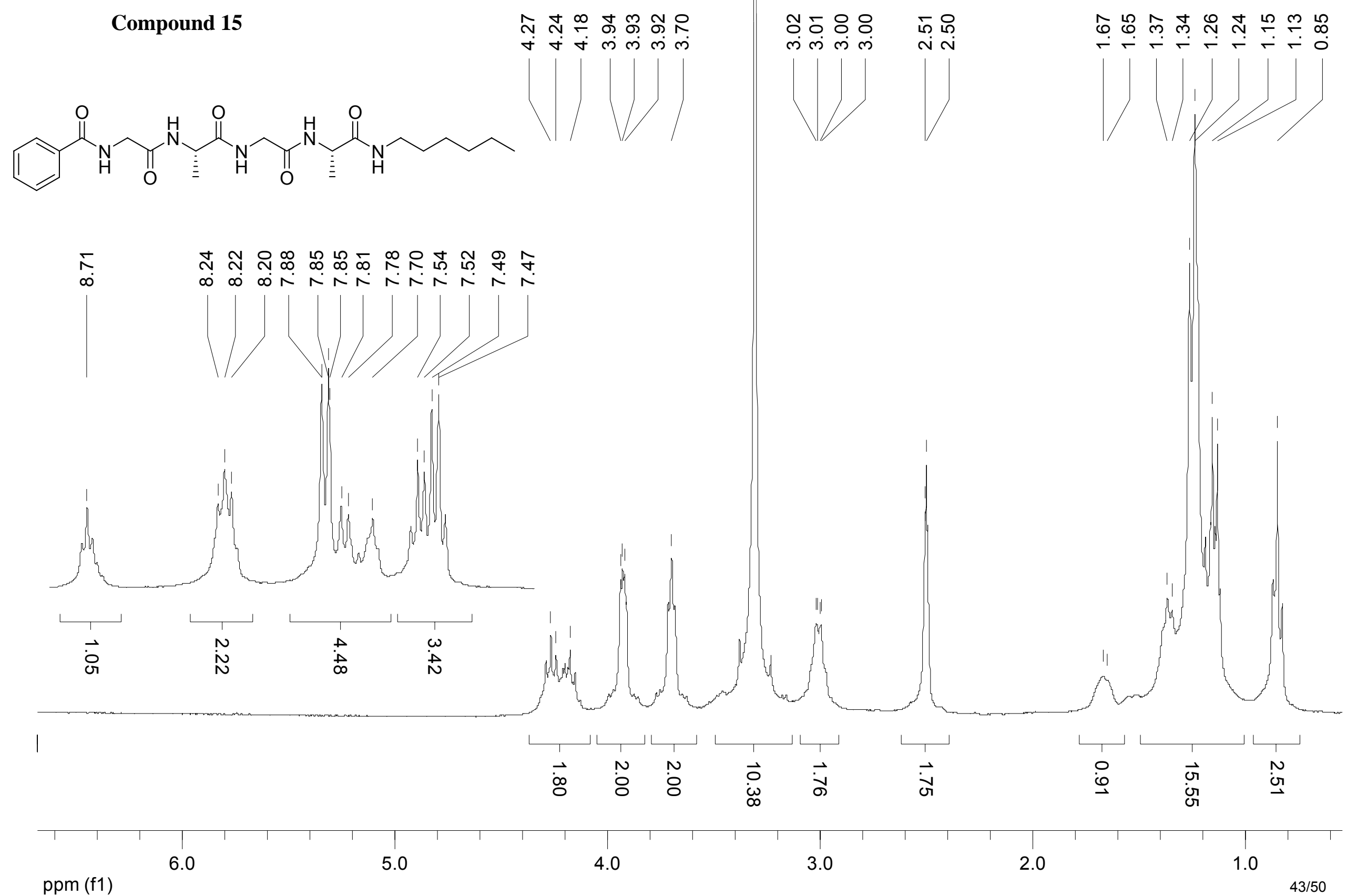




\section{Compound 15}

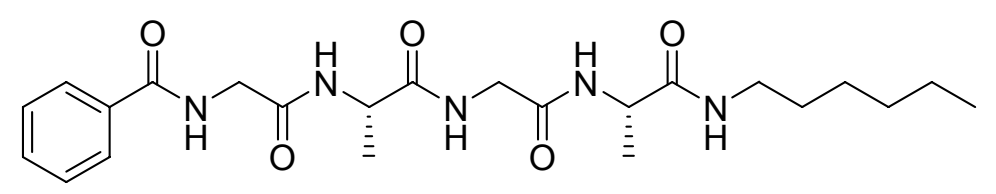

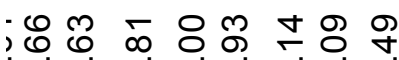

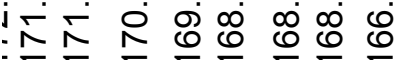

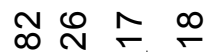

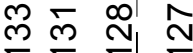

Lิ

孛

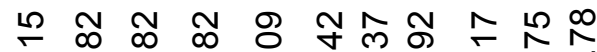

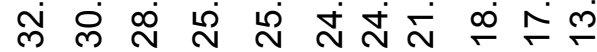

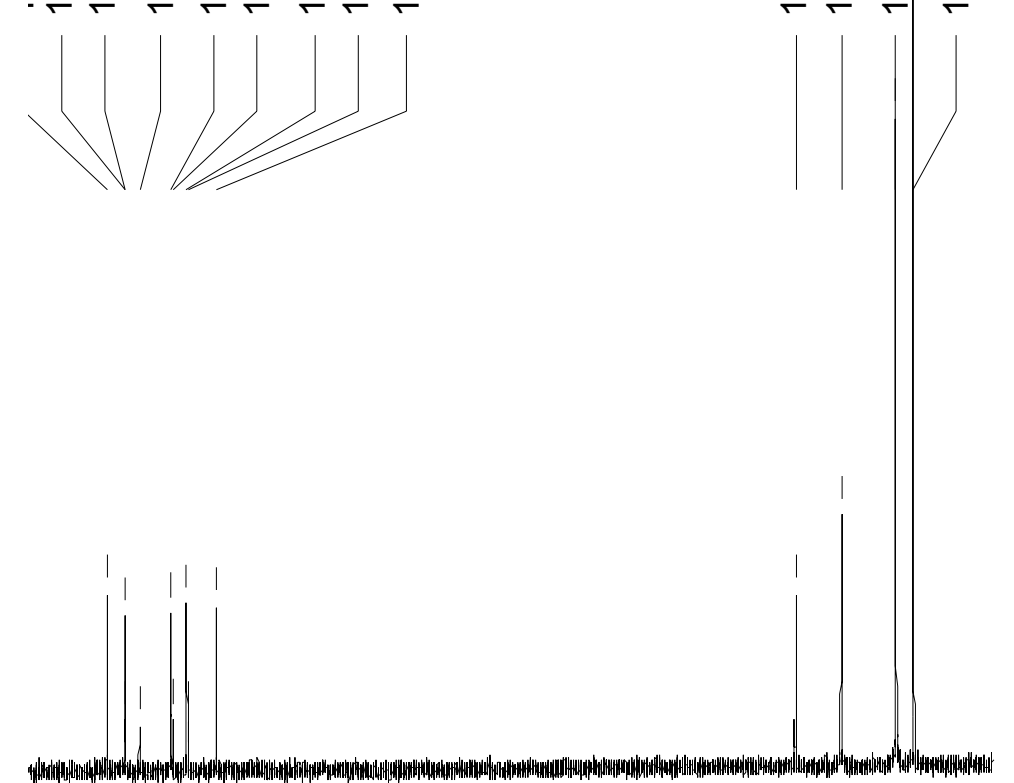

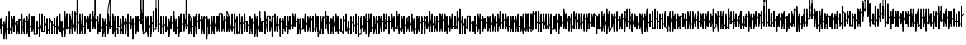
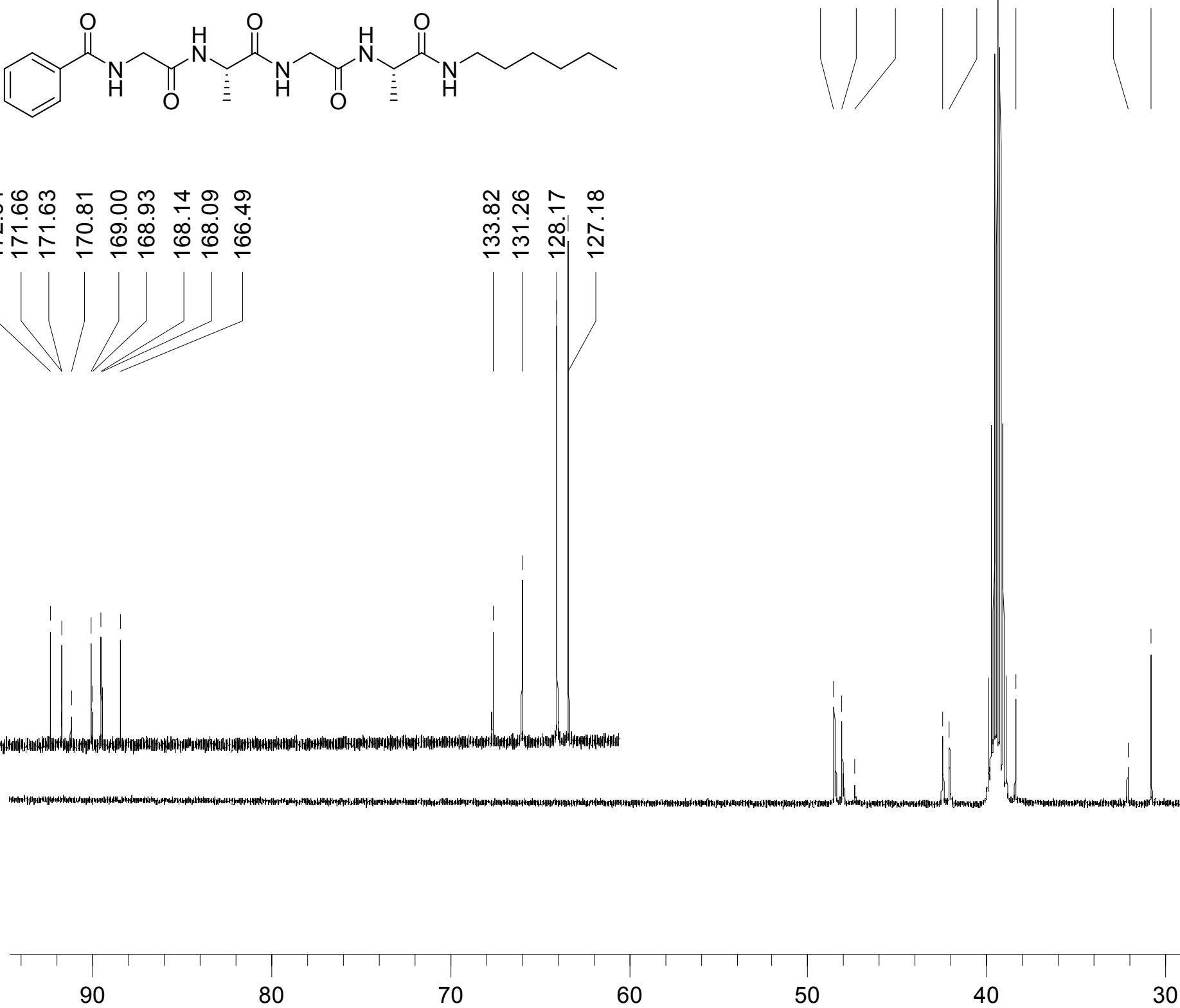

80

70

60

50

40

30

20 


\section{Compound 16}

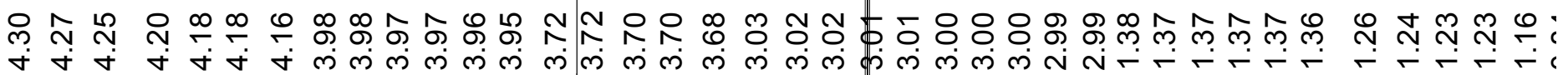<smiles>CCCCCCNC(=O)[C@H](C)NC(=O)CNC(=O)[C@H](C)NC(=O)CNC(=O)c1ccc([N+](=O)[O-])cc1</smiles>

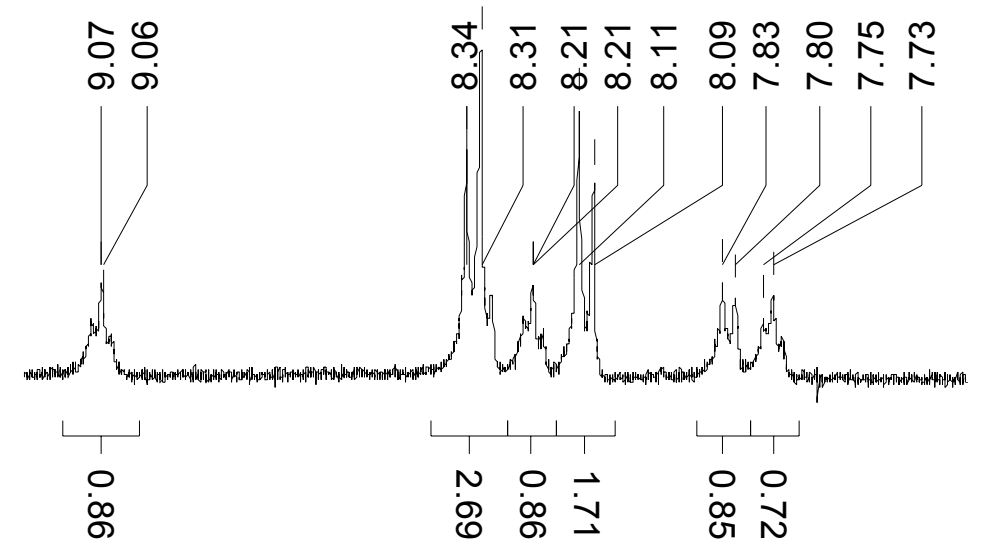

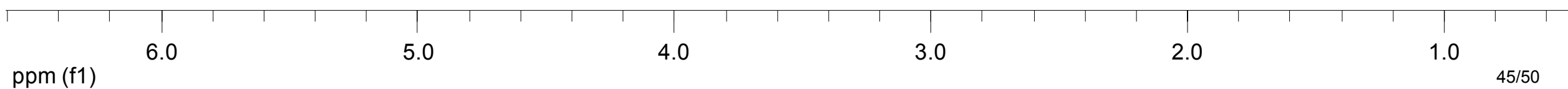




\section{Compound 16}<smiles>CCCCCCNC(=O)[C@H](C)NC(=O)CNC(=O)[C@H](C)NC(=O)CNC(=O)c1ccc([N+](=O)[O-])cc1</smiles>

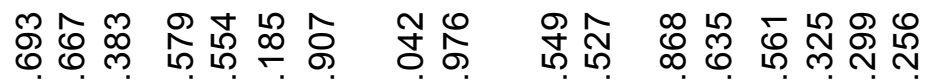

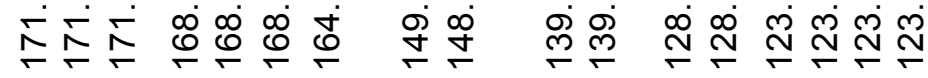

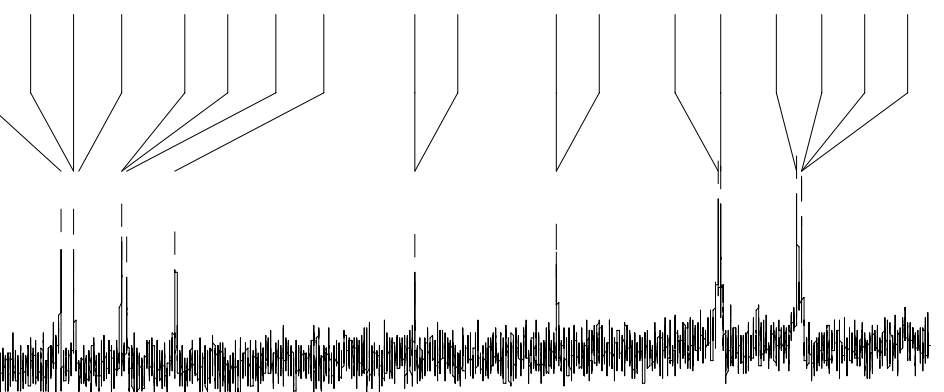

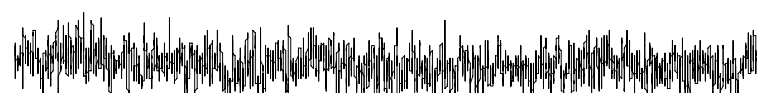

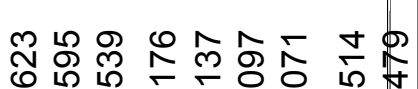

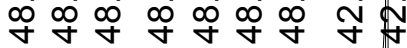

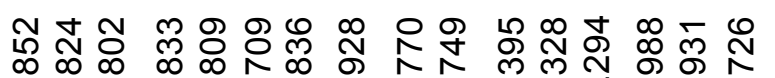

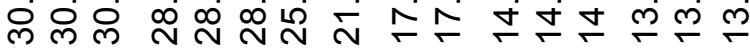
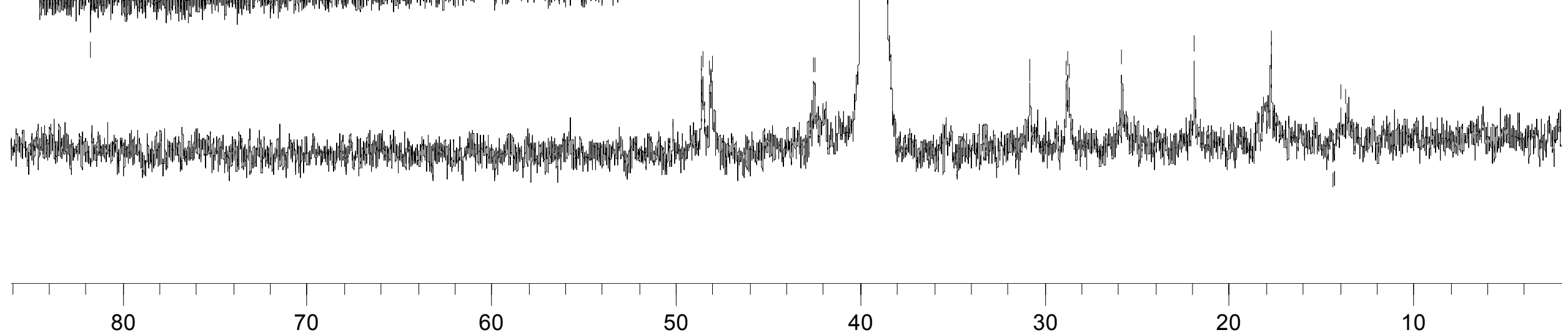

80

70

50

40

30

20 


\section{Compound 17}

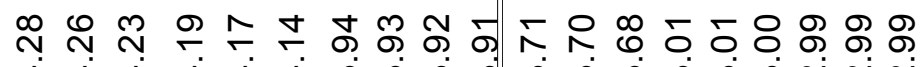

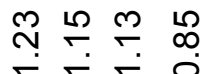

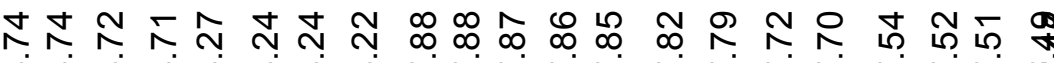

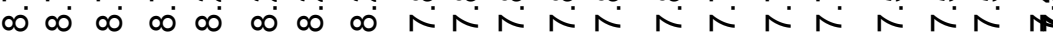
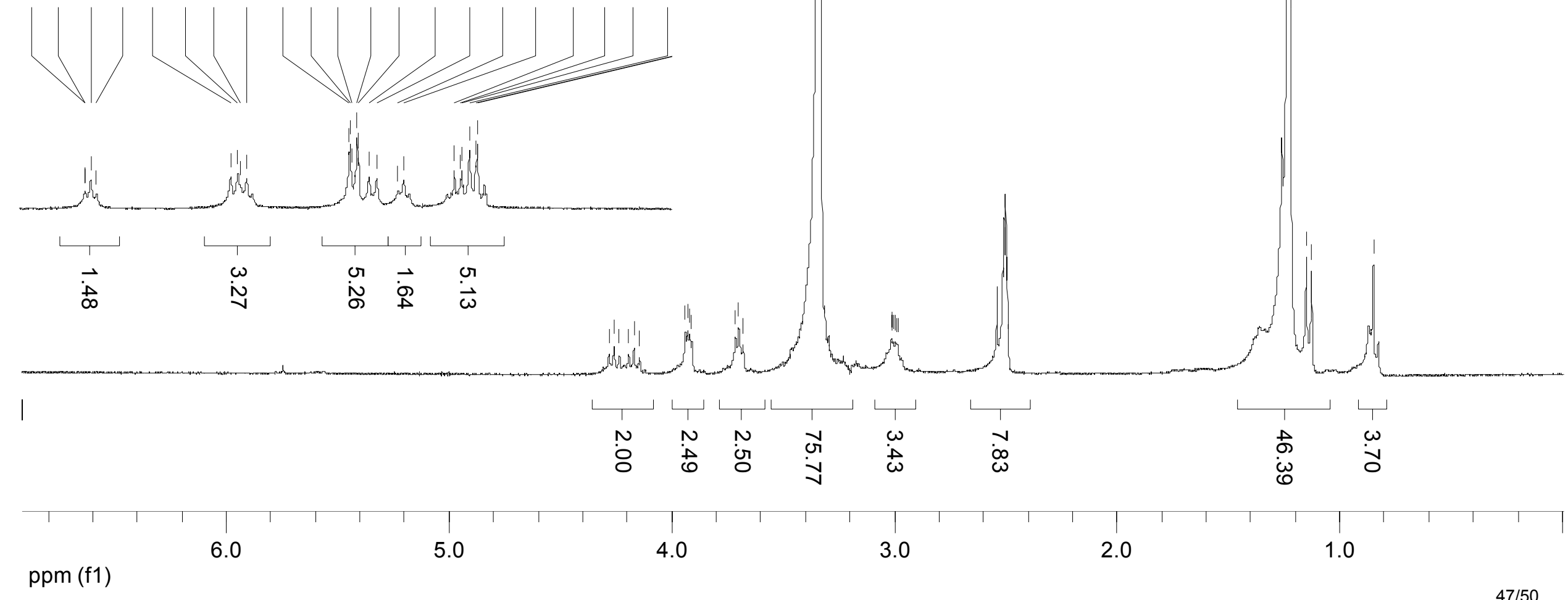

ppm (f1) 


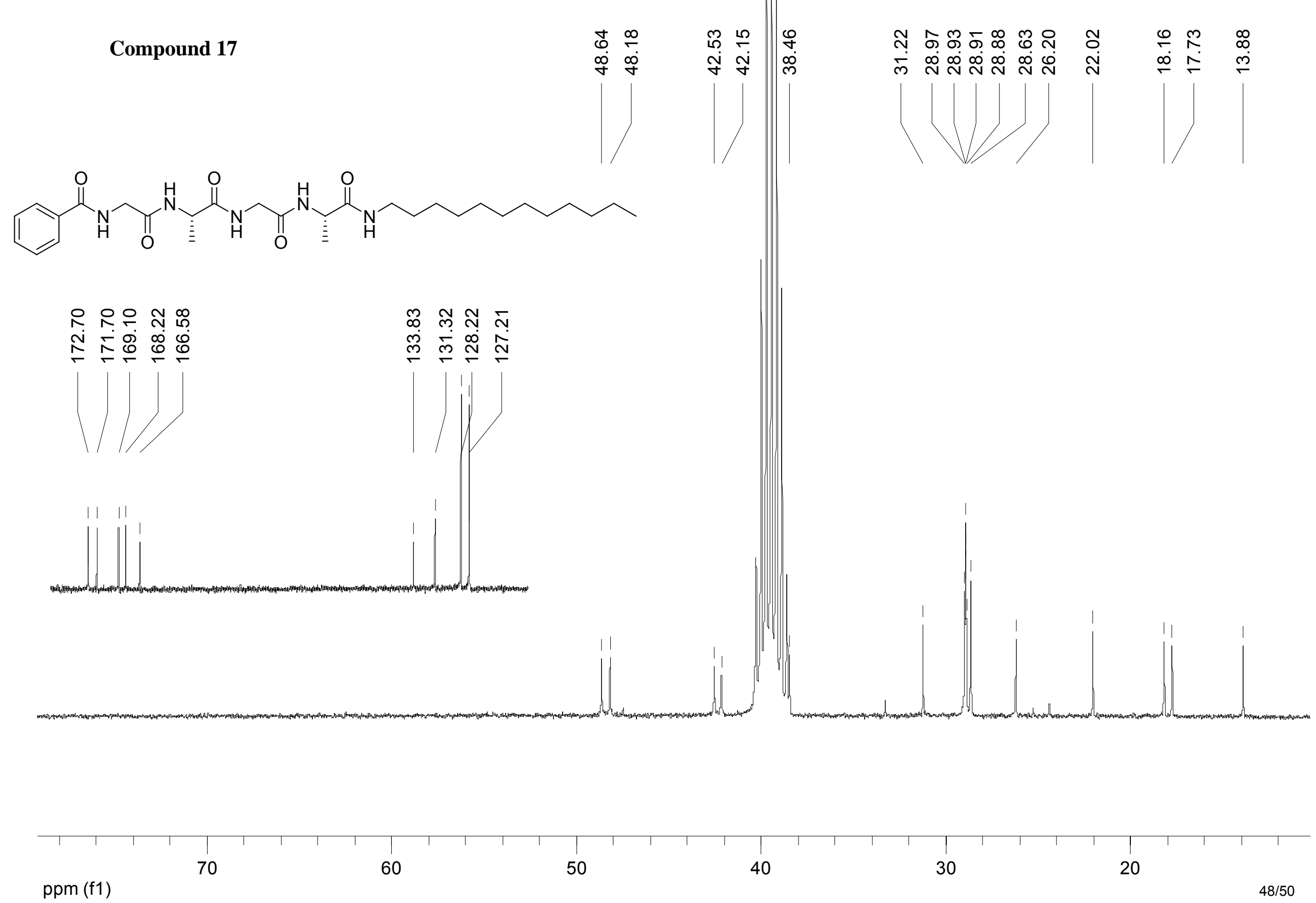




\section{Escuder et al.}

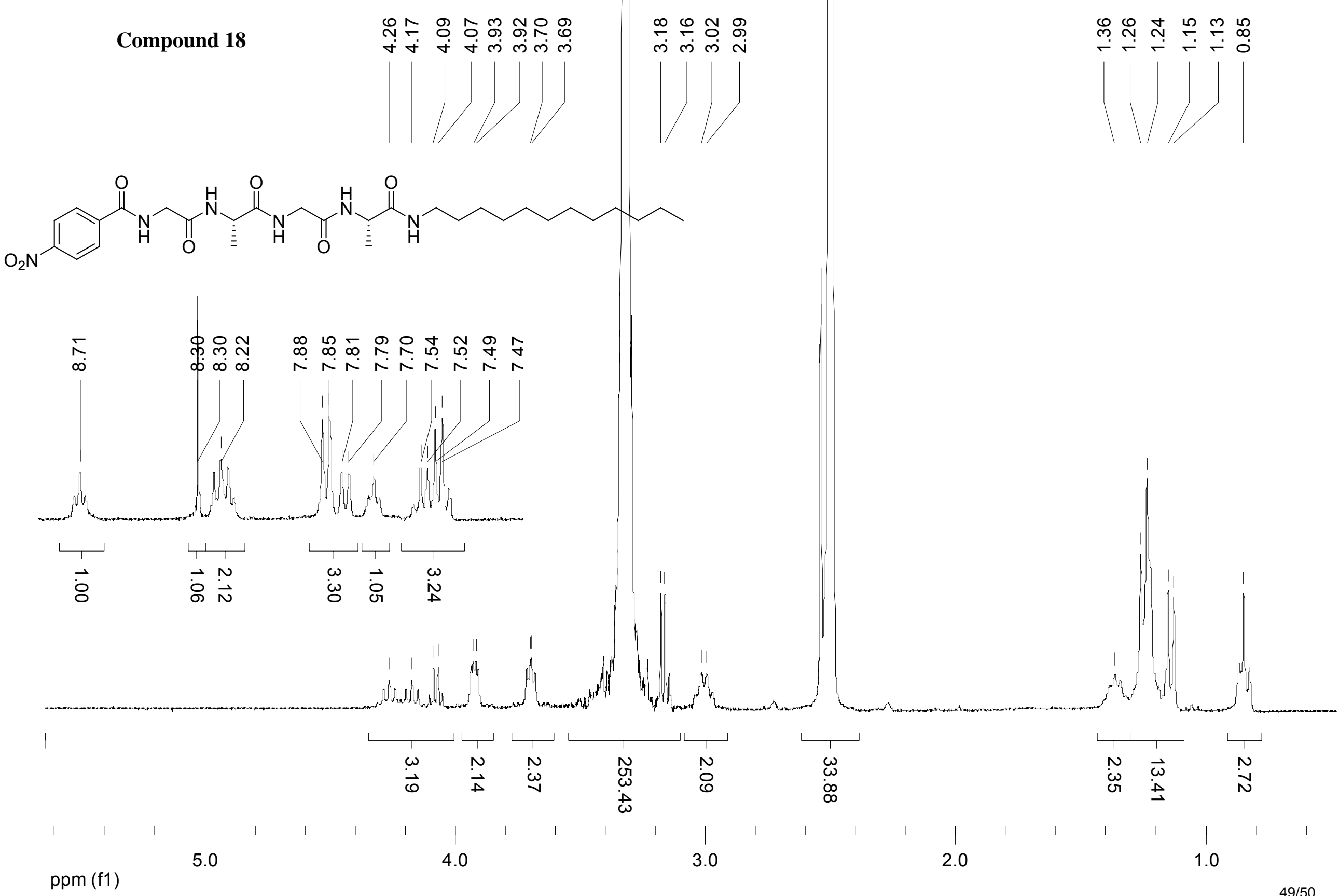

Biomimetic Self-assembly of Tetrapeptides into Fibrillar Networks...

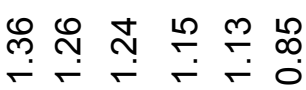


Escuder et al

Compound 18

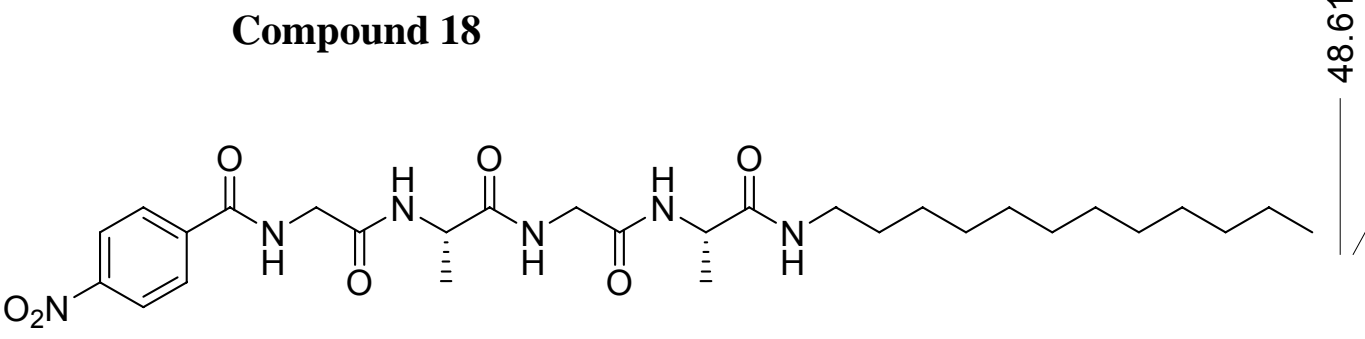

ํำㄷำ ำㅇ

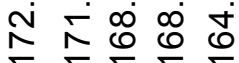

$\stackrel{2}{\circ} \stackrel{\circ}{\circ}$

요 $\quad 9$

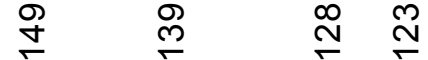

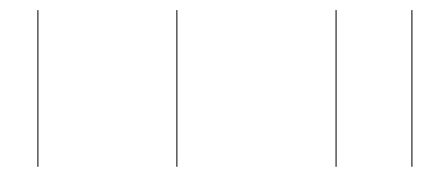

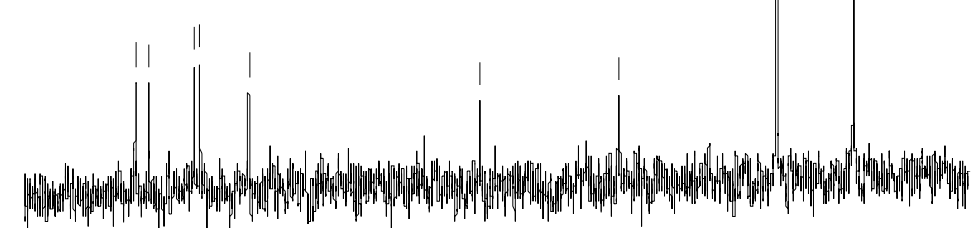

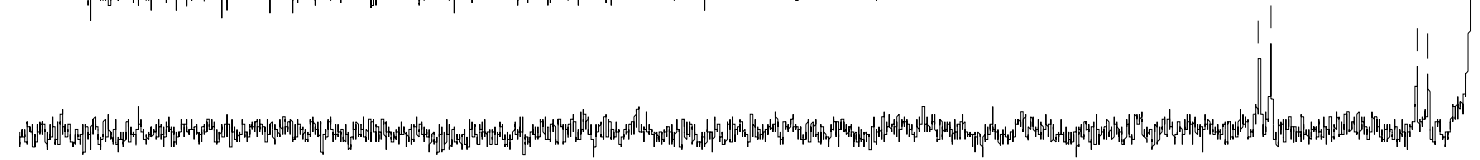

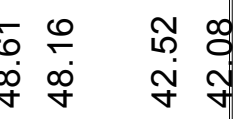

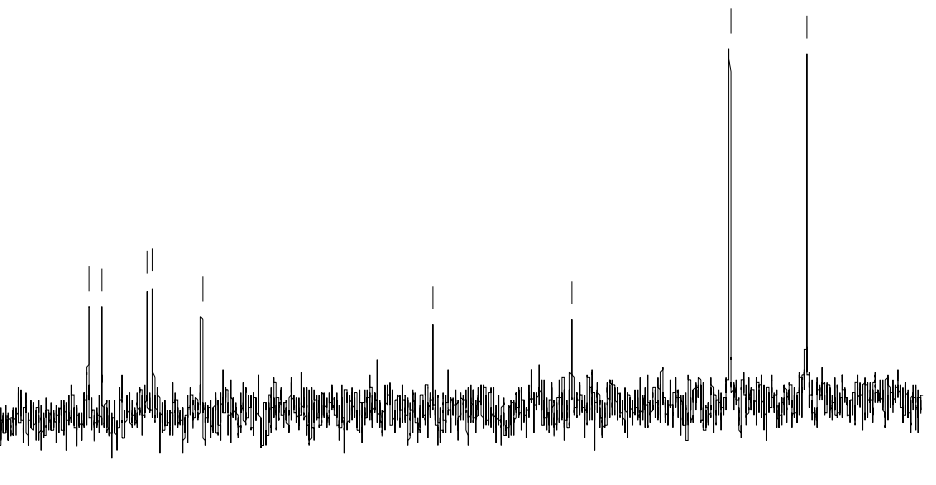

Biomimetic Self-assembly of Tetrapeptides into Fibrillar Networks...

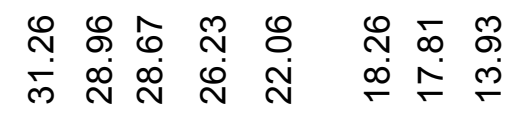

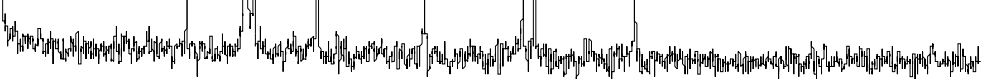

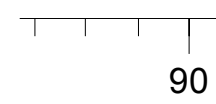

80

70

60

50

40

30

20

$50 / 50$ 